\title{
Future job opportunities in the European Union : towards a EURES database on regional labour market forecasts
}

Citation for published version (APA):

de Grip, A., Matheeuwsen, A., \& Hoevenberg, J. (1996). Future job opportunities in the European Union : towards a EURES database on regional labour market forecasts. Researchcentrum voor Onderwijs en Arbeidsmarkt, Faculteit der Economische Wetenschappen. ROA Reports No. 5E https://doi.org/10.26481/umarep.199605E

Document status and date:

Published: 01/01/1996

DOI:

10.26481/umarep.199605E

Document Version:

Publisher's PDF, also known as Version of record

Please check the document version of this publication:

- A submitted manuscript is the version of the article upon submission and before peer-review. There can be important differences between the submitted version and the official published version of record.

People interested in the research are advised to contact the author for the final version of the publication, or visit the DOI to the publisher's website.

- The final author version and the galley proof are versions of the publication after peer review.

- The final published version features the final layout of the paper including the volume, issue and page numbers.

Link to publication

\footnotetext{
General rights rights.

- You may freely distribute the URL identifying the publication in the public portal. please follow below link for the End User Agreement:

www.umlib.nl/taverne-license

Take down policy

If you believe that this document breaches copyright please contact us at:

repository@maastrichtuniversity.nl

providing details and we will investigate your claim.
}

Copyright and moral rights for the publications made accessible in the public portal are retained by the authors and/or other copyright owners and it is a condition of accessing publications that users recognise and abide by the legal requirements associated with these

- Users may download and print one copy of any publication from the public portal for the purpose of private study or research.

- You may not further distribute the material or use it for any profit-making activity or commercial gain

If the publication is distributed under the terms of Article 25fa of the Dutch Copyright Act, indicated by the "Taverne" license above, 


\title{
Future Job Opportunities in the European Union
}

\author{
Towards a EURES Database \\ on regional labour market forecasts
}

ROA-R-1996/5E

Andries de Grip

Astrid Matheeuwsen

Jeroen Hoevenberg

Research Centre for Education and the Labour Market

Faculty of Economics and Business Administration

University of Limburg

Maastricht, June 1996 
ISBN 90-5321-182-9 


\section{Contents}

Page

Foreword

1 Introduction

2 Research model 5

2.1 The general structure of the model 5

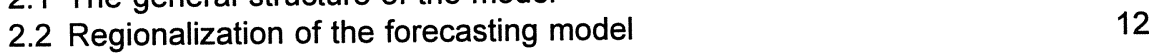

3 Availability of sectoral forecasts $\quad 15$

$\begin{array}{ll}3.1 \text { Introduction } & 15\end{array}$

$\begin{array}{ll}3.2 \text { A decentralized approach } & 15\end{array}$

3.3 Coordinated approaches $\quad 24$

4 Availability of data for occupational and educational forecasts 29

4.1 The required data 29

4.2 Data availability at the European level 33

4.3 Occupational specialization of the EU Member States 48

5 National and regional forecasts for the Netherlands 53

5.1 ROA's information system on education and the labour market 53

5.2 National forecasts by economic sector, occupation and educational
qualification

5.3 Regional forecasts by occupation 66

6 National and regional forecasts for the United Kingdom 77

$\begin{array}{ll}6.1 \text { IER's approach } & 77\end{array}$

6.2 National forecasts by economic sector, occupation and educational
qualification

6.3 Regional employment forecasts by economic sector and occupation 86

7 Conclusions $\quad 95$

$\begin{array}{ll}\text { References } & 101\end{array}$

Appendix A Presentation of information on the future job opportunities in the Netherlands for the EURES system

Appendix B Presentation of information of future job opportunities in the United Kingdom for the EURES system

Appendix C Regional, Occupational and Economic sector classifications EUROSTAT

$\begin{array}{lll}\text { Appendix D } & \text { IER's educational qualification } & 117\end{array}$

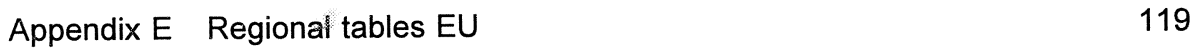





\section{Foreword}

This report presents the results of an inventory of the possibilities of generating medium-term labour market forecasts by economic sector, occupation and type of education for the various regional labour markets in the European Union. These forecasts need to be developed to supplement the information available in the EURES General Information Database. This labour market information could inform potential migrants or cross-border commuters about the employment opportunities in the various regions of the EU Member States. It could also serve to indicate the labour market prospects for international firms which are considering starting or expanding their production or services in a particular region of the European Union.

The authors would like to express their thanks to Professor Robert Lindley (Director of the Institute for Employment Research, Coventry, U.K.) and André Dewez and Nannette Ripmeester (EURES, DG V) for their comments on earlier drafts of this report. 



\section{Introduction}

Since finding 'the right job' is mainly an individual search process, it is very important to increase the transparency of the European labour market for those who are familiarizing themselves with job opportunities in other Member States of the European Union (Cf. Van Dam, De Grip and Heijke, 1993). In fact, giving adequate information on the employment opportunities in the various EU Member States is the main aim of the EURES Network set up by the European Commission.

EURES has a major role to play in the realization of an integrated European labour market, in the sense that it aims to inform both individual job seekers and firms on the labour market opportunities in the various Member States of the European Union. The available information on the jobs on offer in the various Member States reflects the actual mediation function of the EURES system. Moreover, the EURES General Information Database informs potential migrants or commuters about the living and working conditions in the Member States and also presents more general regional labour market information.

Information on the expected trends (i.e. medium-term forecasts) on the labour market in the various regions of the EU Member States will also be an important aid to 'enlarging the horizons' of potential migrants or commuters. Moreover, this information also serves to signal the labour market prospects for international firms which are considering starting or expanding their production or services in a particular region of the European Union.

A transparent integrated European labour market is an important tool to improve the match between labour demand and supply on a European scale. Particularly in the border regions of the Member States, the match between the various kinds of potential employers and employees suffers from the limited scale of the peripheral labour market due to the restricted geographical mobility of the labour force. Moreover, the introduction of the Economic and Monetary Union (EMU) will probably increase the importance of an integrated European labour market. It will become impossible to cope with macro-economic disequilibria due to external shocks by means of exchange rate adjustments, so labour mobility from high unemployment regions to low unemployment regions will probably become a more important adjustment mechanism.

However the EURES General Information Database does not yet include trends in the supply and demand in the regional labour markets by economic sector, occupational class or type of education. A Labour Market Information model needs to be developed to enable the Commission to supply this labour market information for 
the intended user groups. Generating the various forecasts for economic sectors, occupational classes and types of education at a regional level requires a large data input and a substantial research effort. For this inventory study we therefore propose a 'dual' approach.

First, research will be done on the possibilities of generating the required mediumterm forecasts. Here the main focus is on:

1. The formulation of a modular forecasting model that can be developed stepwise and which respects the principle of subsidiarity, in the sense that it builds on the existing national forecasts in the Member States which are imbedded in public policies in general or the particular policies of Public Employment Services.

2. An investigation of the way in which the forecasts by occupation and type of education can build on (1) the available official national sector models and (2) previous coordinated research projects which were intended to generate employment forecasts for all EU Member States.

3. An investigation of the possibilities of the available EUROSTAT data. ${ }^{1}$ In particular, it will be necessary to determine the optimal level of aggregation of economic sectors, occupations, and types of education for the forecasts with respect to the 163 regions distinguished in the EURES database (i.e. more or less similar to the NUTS 2 regional level). This will provide a clear picture of the possibilities of generating the same kind of information for all EU Member States.

Second, two prototype forecasts relating to the information available for the Netherlands and the United Kingdom will be presented. The information for the Netherlands is based upon ROA's experience with data and forecasts for this Member State. The information for the United Kingdom is based on the forecasts of the Institute of Employment Research (IER). The advantage of this second line of research is twofold. In the first place it will produce two operational examples of the labour market information that can be given in the 'Trends' section of EURES' Labour Market Information Treechart. In the second place, it shows the consequences of the subsidiary approach, in the sense that somewhat different information will be presented for the various Member States.

To limit the scope of this second line of research, the main focus will be on the possibilities and structure of a basic model, and relatively little attention will be paid to dealing with incidental problems that may be relevant for the quality of the forecasts in operational use. The forecasts should therefore be seen as prototypes,

1. An initial study of this point, commissioned by DG V, was carried out by ROA in 1993. (see Hoevenberg and De Grip, 1994) 
which could serve as benchmarks for the future development of the EURES 'Trends' information.

Since it is very important that EURES' labour market information is suitable for those familiarizing themselves with employment opportunities in other Member States, some consideration will also be given to how the large output of forecasts by economic sector, occupational class and type of education for each region can be presented in a transparent way, and combined where appropriate with the information generated by EURES' survey among the EURO advisers of the Public Employment Services in the various regions of the European Union: the PES Questionnaire.

The remainder of this report is structured as follows. Chapter 2 describes the proposed forecasting model beginning with an overview of the general structure of the research model to clarify the approach. Section 2.2 then indicates the procedures required to generate the needed data at the regional level distinguished in the EURES Database. Chapters 3 and 4 discuss the availability of the required data. Chapter 3 deals with the availability of sectoral forecasts for the various EU Member States while chapter 4 deals with the availability of the required data input for modelling the occupational and educational forecasts. Chapters 5 and 6 present the available national and regional forecasts for the Netherlands and the United Kingdom. Chapter 5 outlines ROA's information system on education and the labour market, with section 5.2 presenting ROA's national forecasts by occupational classes and educational qualifications. Section 5.3 presents regional forecasts of the expansion demand. Chapter 6 discusses IER's approach to labour market forecasting. Section 6.2 presents the available national forecasts of expansion demand by economic sector, occupation and forecasts with respect to Higher Education. In addition section 6.3 gives the regional forecasts of expansion demand for the United Kingdom, as constructed by the IER. As an aid to visualizing the information on future job opportunities that could be presented in the EURES system, proposals for the computer screen text with respect to the various regions in the Netherlands and the United Kingdom are given in Appendices A and B, respectively. Finally, Chapter 7 summarizes the main conclusions on the possibility of generating the proposed medium-term labour market forecasts for the EURES Database. Moreover, some conclusions will be drawn with respect to the further development of the required labour market forecasts for the EU Member States on behalf of the EURES Database. 



\section{Research model}

\subsection{The general structure of the model}

In the 1960s the manpower requirement approach was used as a planning instrument. One response of the advocates of this approach to severe criticism of its usefulness for planning purposes was to switch the function of manpower forecasts to the generation of information for the various participants on the labour market (see Van Eijs, 1994 and OECD, 1994). The prime purpose of the forecasts should therefore be informational: to increase the transparency of the match between labour demand and supply on the, labour market. Moreover, drawing up labour market forecasts is more promising today than in the past, because of the more regular availability of labour market data from the Labour Force Survey in the various Member States of the European Union.

The most effective approach for generating medium-term labour market forecasts for both occupational categories and educational qualifications in the various Member States of the EU is obviously, a modular research model. First, a modular approach makes it possible to set up the requested labour market forecasts step-by step. Second, with a modular approach it is possible to make allowance for the substantial differences between the various Member States in both the available labour force and student data and the macro-economic or sectoral forecasts.

Figure 2.1 shows the general structure of the research model that generates the required medium-term forecasts. ${ }^{2}$ In its most elaborate form a total of eight modules constitute the labour market information system. If all these modules are developed the information system will produce three kinds of key information which provide the labour market signals that are relevant for the intended user groups:

- the expansion demand by economic sector;

- the job openings by occupation;

- the labour market prospects by educational qualification.

2. Figure 2.1 refers to the general structure of the research model. Section 2.2 describes the modelling of the regionalization of the various forecasts. 
Figure 2.1

Overall structure of the research model for medium-term labour market forecasts.

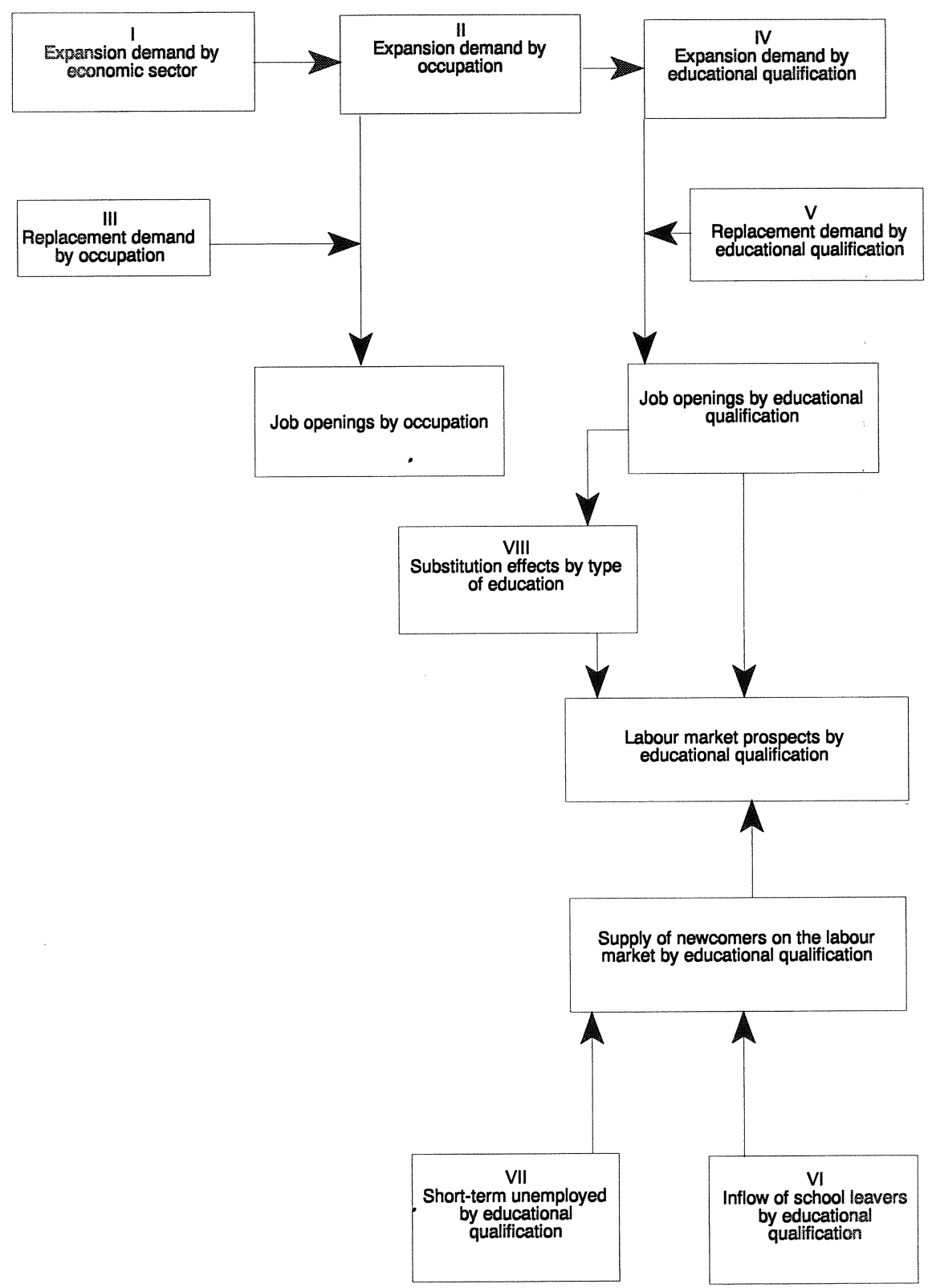


The information on the job openings by occupation is generated by the first three modules. Module I produces the expansion demand by economic sector (i.e. the expected employment growth). These employment forecasts should be funded in a macro-economic model that differentiates between the various economic sectors. In such a multi-sector model, which is usually developed to generate the benchmarks required for general economic and employment policies, many interrelated financial and socio-economic variables influence the economic and employment forecasts.

Module II refers to the occupational model that transforms the employment forecasts by economic sector into the expansion demand by occupation. Since the occupational structure of an economic sector is mainly a reflection of the demand side of the labour market, changes in the occupational structure of employment could be explained by factors which primarily influence the demand for labour (e.g. capacity of production, labour productivity, hours per year worked, use of information technology and a trend term). The macro-economic models that are the basis of the employment forecasts in module I generate the forecasts of all these explanatory variables, except for the growth in the use of information technology. The required historical data on the occupational structure of employment could be derived from the occupation $x$ economic sector matrix of the working population, on the basis of the available Labour Force Surveys and/or Population Censuses.

Module III contains a model of the forecasts of replacement demand by occupation. In general the replacement demand because of the departure of workers is more important than changes in employment levels in determining how many jobs become available for new entrants of the labour market (see De Grip, Meyboom and Willems, 1993). The replacement demand results for both permanent withdrawals for the labour force as workers reach retirement age or take early retirement, and temporary withdrawals, especially by married women caring for their own children. The replacement demand is therefore closely related to the age structure and sexual composition of occupations and types of education. In forecasting the replacement demand these two factors therefore play an important role.

The first step in modelling future replacement demand per occupational class is a description of the inflow and outflow pattern by occupational class over a historical period. However, in almost all countries no appropriate data for mobility flows on the labour market is available. For these countries there is a proper alternative approach based on stock data. By means of the so-called cohort components method cohort-change rates based on the number of persons of the same birth cohort who were employed at two different times can be calculated (see Willems and De Grip, 
1993). These cohort-range rates can be rewritten as average annual net inflow or outflow percentages ${ }^{3}$.

$$
{ }_{k} \dot{W}_{o, a}^{t, n}=\sqrt[n]{\frac{{ }_{k} W_{o, a+n}^{t}}{{ }_{k} W_{o, a}^{t-n}}}-1
$$

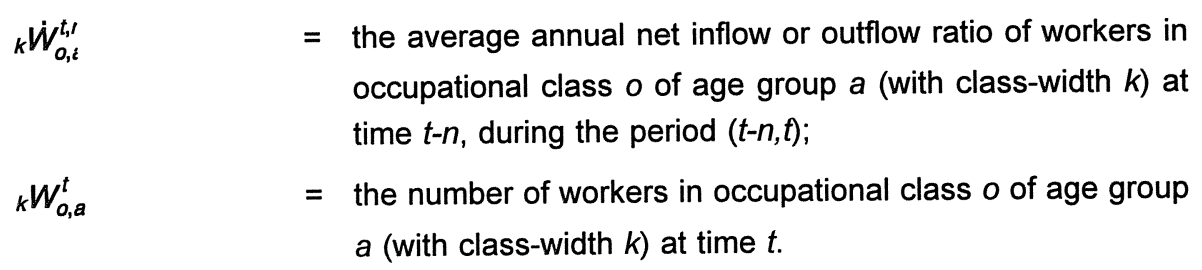

If

${ }_{k} \dot{W}_{o, a}^{t, n}<0$

there is a net outflow for a certain age group from an occupational class, and if ${ }_{k} \dot{W}_{o, a}^{t, n}>0$

there is a net inflow.

The second step in modelling is the translation of these inflow and outflow percentages into the replacement demand by occupational class. For occupational classes with an increase in employment in the period $(t-n, t)$, replacement demand is equal to total net outflow in this period. However, for occupational classes which faced a decrease in employment, not all vacancies due to the outflow of workers will have been filled. Therefore replacement demand for these occupational classes equals the number of vacancies that were actually refilled, that is, the total inflow of workers in the occupational class.

This methodology measures only the net flow to or from an occupational class. This means that replacement demand satisfied by re-entering workers of the same age cohort is not measured. So replacement demand is actually measured for newcomers on the labour market. However, this is exactly what is intended, in as much as the labour market information system should focus on the prospects for newcomers on the labour market. ${ }^{4}$

3. Flow rates for male and female workers are differentiated.

4. In order to cope with changes in the number of workers re-entering the workforce, there should be a correction with respect to the expected changes in the labour market participation rates of the various age-groups of the workforce. 
The third step is to project the historically measured net replacement demand rates per age-sex group for a particular occupational class onto the age-sex structure of the workers at the beginning of the forecasting period. Moreover, the historically observed cohort change rates can be corrected for business cycle effects and for expected changes in participation rates. For more details see Willems and De Grip (1993). The required historical data for forecasting the replacement demand by occupation could be derived from the occupation $x$ age-group $x$ gender matrices of the working population on the basis of the available Labour Force Surveys and/or Population Censuses.

Together, the first three modules make it possible to generate the key information on the job openings by occupation; which is of major importance for the intended user-group of the EURES labour market information.

Module IV is the first step in extending the labour market information with the required information on types of education. In this module the forecasts of the expansion demand by occupation are transformed into the future expansion demand by educational qualification. In the model developed in Borghans and Heijke (1993) the distribution of the educational qualification (e) per occupational segment (o) is determined by the skill structure of this occupation in the most recent year for which observations are available. Because of upgrading or downgrading tendencies and concentration around the average training level for this occupation, the ratios between the shares of the various educational qualification in an occupational segment can shift as follows:

$\bar{W}_{o \theta}=W_{o \theta}^{t-1} e^{\left(-\gamma_{1}\left(5-l_{e}\right)\right)} e^{\left.\left(-\gamma_{2} \mid l_{e}-t_{o}^{t-1}\right)\right)}$

where:

$\bar{a}_{o 6}$

$a_{o \theta}^{t-1}$

$I_{\theta}$

$t_{o}^{t-1}$

$\gamma_{1}$
$=$ number of people with education $e$ in occupation $o$ according to the adjusted qualification structure;

$=$ number of people with educational qualification $e$ in occupation $o$ in the base year;

$=$ the level of educational qualification $e$ (from 1 for primary education to 5 for academic education);

$=$ the average level of the educational qualification in occupation $o$ in the base year;

$=$ coefficient indicating the extent of upgrading or downgrading in a 5 -year period; 
The required historical data on the educational structure of occupational employment could be derived from the occupation $x$ educational qualification matrix of the working population on the basis of the available Labour Force Surveys and/or Population Censuses.

Module $\mathrm{V}$ generates the forecasts of replacement demand by educational qualification. Replacement demand by educational qualification must be interpreted differently from replacement demand by occupational class, since net mobility between occupational classes need only be taken into account in the latter. When a worker with a certain educational background changes occupation, this does not create a vacancy for a newcomer on the labour market with the same educational background. Therefore this does not influence replacement demand for newcomers for the educational qualification in question.

There is another difference between the replacement demand by occupational class and the educational qualification. If someone leaves a certain occupational class and is replaced by an employee with another (e.g. higher) educational background, there is a replacement demand for the occupational class in question. When such displacement or substitution effects occur, however, there is no question of replacement demand for the type of education in question, but rather of an employment decrease for one type of education and an employment increase for the other. ${ }^{5}$

The modelling is similar to the cohort-change rate modelling of the replacement demand described above (module III). The required historical data for forecasting the replacement demand by educational qualification could be derived from the educational qualification $x$ age-group $x$ gender matrices of the working population on the basis of the available Labour Force Surveys and/or Population Censuses.

Together, modules IV and $\mathrm{V}$ generate information on the future job openings by educational qualification. Although this is not the intended final information on the labour market by educational qualification, the information on the job openings by educational qualification is highly rélevant for users of the EURES labour market information.

5. In principle the opposite also holds: if a worker who leaves a shrinking occupational class is not replaced, whereas someone with a similar educational background is recruited in another, growing occupational class, there is replacement demand by type of education but no replacement demand by occupation. 
Module VI supplements the demand-side information on the future job openings by educational qualification with supply-side forecasts of the future labour market inflow of school-leavers. The forecasting model used should be based on a transitionmatrix based on the composition of full-time education and a classification of the population by level of education. Flow coefficients relate the 'origin' of students in year $t$ to the 'destination' of these students in year $t+1$. By means of these flow coefficients, the future numbers of students coming from each educational category can, step-by-step, be forecast. However, such a straightforward approach would suppose that students' choices remain unchanged during the entire forecasting period. Therefore, the flow coefficients of students, which are highly affected by choices and/or selection processes, are considered as the dynamic elements of the model. In general, future changes in these coefficients could be forecast by means of (modified) trend extrapolations. The required information could be derived from recorded data on students in initial education, combined with educational matrices that describe the student flows between the various types of initial education and data on the labour market inflow rates of school-leavers.

It is also necessary to forecast the flow from non-regular education (apprenticeships, recognized correspondence courses, training in medical care etc.) onto the labour market. Data about that category has to be taken from available additional statistics, or obtained directly from the training institutions concerned. Moreover, enrolment in non-regular courses changes the qualification profile of 'school leavers'. For that reason, the number of students who have successfully completed such courses has to be proportionally subtracted from their preliminary regular educational groups. Another correction is needed to prevent students enroling in several non-regular courses or in a regular and non-regular course of the same type being counted twice. In this way a forecast can be drawn up of the flow from both regular and non-regular educational groups onto the labour market. ${ }^{6}$

Module VII refers to the collection of recent data on the numbers of short-term unemployed by educational background. The short-term unemployed workers at the beginning of the forecasting period should be included in the modelling of the future labour market prospects as these workers compete on the labour market with school-leavers with the same type of education. The short-term unemployed and the inflow of school-leavers are combined in the forecast of the future supply of newcomers on the labour market by educational qualification. The requested data could be derived from existing registered data or surveys on unemployment which include information on the educational qualifications of the unemployed workers.

6. See Berendsen et al. (1992) for detailed information about the method and the required data. 
In addition to the two labour supply components dealt with in modules $\mathrm{VI}$ and VII, labour migration between Member States may of course also affect labour supply in the various countries. However, these migration flows are still relatively small. In the period 1989-1991, about 300,000 persons per year migrated to another Member State (see European Commission, 1993). Moreover, since it is an important aim of the EURES information system to generate migration flows that improve the match between labour demand and supply in the Member States, one could argue that the labour market signals EURES gives should not be corrected for these migration flows. $^{7}$

By matching the forecasts of job openings (labour demand) with the forecasts of labour supply, an indicator of the future labour market situation by educational qualification can be constructed. However, in forecasting the labour market prospects by educational qualification, the expected substitution effects between the various skill categories, where ex ante shortages or excess supply are forecast, should be taken into account. Module VIII deals with the 'ex post' substitution effects that may occur between the various types of education. It measures both the negative 'crowding-out' effect and the positive 'pull-effect' for particular types of education due to the excess supply or supply shortages for competing educational qualifications.

\subsection{Regionalization of the forecasting model}

The general structure of the research model is actually an outline of a method for producing national forecasts for the various occupations and educational qualifications. To produce information on the job openings by occupation and the labour market prospects by educational qualification at the NUTS 2 regional level, a topdown procedure that makes it possible to regionalize the national forecasts for the various Member-States is required. Since it is obvious that, for a particular country, the available Labour Force Survey data at the regional level is much less reliable than at the national level, the general procedure should be to project the expected national developments (e.g. shifts in the occupational structure of employment by industry) onto the regional employment structure. However, the regional forecasts of employment growth by economic sector, form an exception on this point.

These regional forecasts of expansion demand by economic sector are the starting point for the regional forecasts. These forecasts should be funded in a multi-regional sector model. Such models usually focus on the explanation of regional diffe-

7. Of course this means that if EURES signals attractive job openings in a particular Member State, too large flows of migrants may be attracted from other Member States. 
rences (the 'regional components') within the national developments of employment by economic sector (see e.g. Natzijl and Westra, 1995).

The regional forecasts by economic sector can be transformed into forecasts of the regional expansion demand by occupation by combining the regional expansion demand forecasts by economic sector with the changes in national employment shares of occupations in the various economic sectors. The advantage of this approach is that the estimates of the shifts in the occupational structure of employment in the various economic sectors can be based on the more reliable national data. However, this approach assumes that national developments are representative of the developments in the regions within the Member State concerned. In general this will be a reasonable assumption. ${ }^{8}$ However, for particular countries with large regional differences in the occupational structure of particular economic sectors, it could be sensible to estimate the models at a more disaggregated level (e.g. the former East and West Germany; North and South Italy).

The regional forecasts of expansion demand by occupation are the starting point of the forecasts of regional expansion demand by educational qualification. The regional occupational forecasts are combined with the national forecasts of employment growth rates for the various types of education in each occupational category.

The forecasts of the regional replacement demand by occupation and type of education can be produced by projecting the national turnover ratios by sex and age category for a particular occupation or educational qualification on the actual sex and age structure of regional employment in that particular occupation or type of education.

The forecasts of the regional inflow of school leavers by educational qualification should be based on regional data on the numbers of students in the educational system, combined with national forecasts of the student flow coefficients between the various types of education. Again, for some countries it is probably better not to rely on national coefficients but on data on a more disaggregated level.

Of course, the regional labour market situation is often affected not only by labour mobility flows between Member States but also by the mobility flows between the various regions in the country concerned. The relative importance of these mobility flows is highly dependent on the scale of the regions and their geographical location. Moreover, the regional mobility of people with high education is usually larger

8. Moreover, feedback from the regional to the national level is ignored (see e.g. Nijkamp et al., 1986). Such interaction effects probably can better be incorporated at a later stage in the development of the European-level research model. 
than the regional mobility of less skilled workers. As it would be very difficult to model these regional labour mobility flows in a reliable way, it is probably better to choose an alternative solution in which the information on regional labour market shortages for a particular type of education is presented in combination with the available information on the labour market prospects of that type of education at the national level of the Member States concerned. 


\section{Availability of sectoral forecasts}

\subsection{Introduction}

This chapter discusses the availability of medium-term sectoral employment forecasts. As mentioned in chapter 2, these forecasts are the required starting points for the forecasts of expansion demand (module I). The availability of these sectoral employment forecasts will be investigated along two lines. First, section 3.2 investigates the possibilities of a decentralized approach in which the prevailing national employment forecasts are used as the basis of the labour market forecasts to be presented in the EURES information system. An advantage of this decentralized approach is that the labour market information presented for the various Member States would be consistent with the forecasts that are the benchmarks for national economic and labour market policies. However, the investigation shows that such sectoral employment forecasts are not available for some countries. Since the EURES information system requires forecasts for all Member States, section 3.3 describes two previous research projects which were intended to generate employment forecasts for all Member States of the European Union. An advantage of such a coordinated approach would be that more or less similar models would be used for all Member States. Moreover, coordinated model-building makes it possible to link the various national models.

\subsection{A decentralized approach}

To investigate the possibilities of a decentralized approach consistent with the existing economic forecasts in the various Member States, we made an inventory of the medium-term employment forecasts broken down by economic sector and produced on a regular basis in the various EU Member States. In this approach the starting points for forecasting employment by occupations and types of education i.e. the forecasts of expansion demand by economic sector, are derived for each country in the EU from the work of national institutes. The availability of sectoral employment forecasts in each EU Member State is discussed below.

\section{Austria}

In Austria the Austrian Institute of Economic Research (Österreichisches Institut für Wirtschaftsforschung, WIFO) provides employment forecasts by economic sector on an annual basis. The sectoral employment forecasts cover both the short (1 year) and medium-term (5 years), and regional forecasts are also produced. The forecasts are broken down by 13 economic sectors (In the future 19 economic sectors will be distinguished). These sectors are: 
- Agriculture and energy

- Utilities

- Basic materials

- Textiles, leather etc.

- Basic needs

- Technology sector

- Construction

- Trade

- Tourism industry

- Transport and communication

- Finance and insurance

- Personal private services

- Public services

These economic sectors are defined in accordance with the NACE classification. The forecasts are made on behalf of the Ministry of Labour and the Austrian Public Employment Services. The forecasts are published by the Labour Market Service. The most recent publication is Arbeitsmarktvorschau 1996.

Belgium

In Belgium the Federal Planning Bureau is involved in constructing employment forecasts on a regular basis. Twice a year the Federal Planning Bureau provides medium-term (5-year) forecasts of employment by economic sector, using the HERMES model (see section 3.3). This model distinguishes nine economic sectors:

- Agriculture

- Consumer goods

- Equipment

- Intermediate goods

- Building and construction

- Tradeable services

- Transport and communication

- Energy

- Non-tradeable services

These economic sectors are defined in accordance with the NACO/CLIO ${ }^{9}$ classification (at the 2-digit level). The forecasts are published in the Economische vooruitzichten. The most recent publication is Economische vooruitzichten 1996-

9. NACE/CLIO is a 'product' classification used in input-output tables (national accounts). The NACE/CLIO classicification is compatible with NACE classicification which is an 'activity' classicification. 
2000. The employment forecasts by economic sector provided by the Federal Planning Bureau are not regionally disaggregated. However regional employment forecasts are provided irregularly, based on the MURENA module.

\section{Denmark}

In Denmark several institutes provide forecasts on employment, at the national and regional levels. However, these forecasts are generally not coordinated, and the guidelines are not consistent over time. ADAM (Annual Danish Aggregated Model) is a widely used macro-economic model of the Danish economy, developed by the Danish Statistical Bureau and associated researchers. The model distinguishes 19 economic sectors, but the forecasts are published on a much more aggregated level. The economic sectors distinguished are based on the 117 sectors distinguished in the national accounts, which are in turn based on the International Standard Industrial Classification (ISIC) '68. The ADAM model is used for forecasting from one to five years ahead. The Ministry of Economic Affairs presents employment forecasts by economic sectors, using the ADAM model, around four times a year. These forecasts cover the medium-term ( 2 years) and are broken down by 5 economic sectors. ${ }^{10}$ The forecasts are published in Okonomisk Oversight, the most recent being released in December 1995. The sectors distinguished, are:

- Agriculture etc.

- Manufacturing, industry etc.

- Construction

- Private service sector

- Government (or Public) sector

\section{Finland}

In Finland there are two institutes that provide sectoral employment forecasts: the Research Institute of the Finnish Economy (ETLA) and the Ministry of Finance.

The economics department of the Ministry of Finance publishes forecasts of employment by economic sector twice per year. Each year in February they provide a one-year ahead employment forecast, which is published in the National February Budget for that year. Each September the department makes a two-year ahead

10. The Ministry of Finance, using the same model, provides longer term forecasts, which are consistent with these forecasts. The Economic Council of the Labour Movement and the Danish Economic Council also provide medium-term (3 years) sectoral employment forecasts which distinguish 6 and 3 sectors, respectively. The Economic Council of the Labour Movement has occasionally also published a more disaggregated employment forecast by economic sectors. But this was done in special studies, not on a regular basis. 
forecast of sectoral employment. These forecasts are published in the Economic Survey. In both cases the definitions of the economic sectors are based on the standard industrial classification (SIC). The two-year ahead employment forecast is broken down by 6 economic sectors. ${ }^{11}$

The second institute providing sectoral employment forecasts, ETLA, publishes forecasts four times a year. The quarterly forecasts are published in The Finnish Economy. ${ }^{12}$ The forecasts of employment by economic sector are not provided quarterly, but three times a year. Two-year sectoral forecasts are published in March and September, and a five-year forecast of employment by economic sector is published annually in June. ETLA distinguishes 9 economic sectors. ${ }^{13}$ These sectors are based on the standard industrial classification (SIC 1988). The economic sectors are:

- Agriculture

- Forestry

- Industry

- Construction of buildings

- Civil engineering

- Wholesale and retail trade

- Transport and communication

- Finance and insurance

- Public and other services

ETLA's medium-term forecasts are most appropriate for the purposes envisioned in this study, since they cover the desired medium-term period and utilize the most disaggregated sectoral level for Finland.

France

In France Le Bureau d'Information et de Prévision Economique (BIPE) provides sectoral employment forecasts for the medium term,using the DIVA model. The sectoral forecasts are made 2 or 3 times a year. BIPE distinguishes 36 economic sectors, which are classified in accordance with La Nomenclature des Activités et des Produits (NAP). However, these employment forecasts are not published.

11. In addition to these sectors, there is a category of 'branch unknown'.

12. The Finnish Economy is an abridged edition of the Finnish language publication Suhdanne.

13. In addition to these 9 economic sectors, they also have a category for 'unknown activity'. For presentational purposes some of these sectors are combined into 7 economic sectors. 
In Germany the Institute of Employment Research (Institut für Arbeitsmarkt- und Berufsforschung, IAB) provides sectoral employment forecasts. Since 1989/90 the $I A B$ has been using the econometric macromodel SYSIFO. This model is a quarterly simulation model for West Germany with a submodel for East Germany. It provides forecasts of employment by economic sector for the medium and longterm. SYSIFO distinguishes 14 economic sectors, which are:

- Agriculture, hunting, forestry and fishing

- Energy

- Mining production

- Basic materials industries

- Investment goods industries

- Consumer goods industries

- Food industries

- Construction

- Wholesale and retail trade

- Transportation and communication

- Other services

- Finance and insurance

- Government

- Private households, nonprofit organizations

\section{Greece}

In Greece there is no institute which provides regular employment forecasts. Some forecasts on employment are occasionally made by researchers for their own purposes. ${ }^{14}$ The Centre for planning and economic research (KEPE) has provided some employment forecasts (see for example Glytsos, 1993). These begin with output and productivity forecasts at the one-digit industry level, which are then translated into employment by industry and occupational employment by region.

Ireland

In Ireland the Training and Employment Authority (FAS) is involved in a manpower forecasting project, together with The Economic and Social Research Institute (ESRI). This project produces occupational employment forecasts for the Irish labour market, among other things. In order to make these forecasts, they use

14. The Experimental Institute of Training and Employment (PIEKA) has made some plans to provide employment forecasts. 
sectoral employment forecasts derived from the ESRI medium-term econometric model, in which 11 economic sectors are distinguished. The ESRI provides these forecasts at approximately two-years intervals. The sectoral employment forecasts are presented in the Medium-Term Review which the ESRI publishes. The most recent Review is the Medium-Term Review 1994-2000. The 11 economic sectors distinguished are:

- Agriculture

- Food processing

- Traditional manufacturing

- Utilities

- High technology

- Building

- Distribution

- Transport and communication

- Other market services

- Health and education

- Public administration

These economic sectors are defined in accordance with the NACE classification

Italy

In Italy, the Banca Commerciale Italiana provides sectoral employment forecasts. The forecasts cover both the short ( 2 years) and medium term (5 years). The short term forecasts are provided twice a year while the medium term forecasts are made annually. The employment forecasts are broken down by 37 economic sectors. However these economic sectors cover only the manufacturing industry. These forecasts are published in the Italian manufacturing industry, Trends and Forecasts to 2000 , which is a translation from Analisi dei Settori Industriali.

Luxembourg

In Luxembourg, the Service central de la statistique et des études économiques (STATEC) used to publish regular employment forecasts by economic sector. At this moment STATEC publishes short-term forecasts of the total number of wage earners twice a year. These forecasts are, published in the Note de conjoncture. STATEC, however does not provide medium-term forecasts.

The Netherlands

In the Netherlands the Central Planning Bureau (CPB) provides sectoral employment forecasts using Athena, their multi-sectoral macromodel of the Dutch 
economy. The model distinguishes 14 economic sectors, classified according to the standard industry classification of Statistics Netherlands (comparable to ISIC and NACE). Each year the CPB makes short-term sectoral employment forecasts, and they also provide medium-term forecasts of employment by economic sector at fouryear intervals. The most recent medium-term forecasts are presented in the Centraal Economisch Plan 1993 and cover the period 1995-1998. For forecasting purposes, ROA combines two economic sectors regarding energy which are distinguished by the CPB. The 13 economic sectors distinguished by ROA are:

- Agriculture and fisheries

- Food and beverage industry

- Other industry

- Chemicals

- Metal and electrical industries

- Energy

- Construction

- Commerce

- Transport, storage and communication

- Other commercial services

- Financial services

- Non-commercial services

- Civil services, police, defense and education

Spain

In Spain the Fundacion Tomillo, Centro de estudios economicos produces annual forecasts of employment by economic sector. These broken forecasts cover a period of five years and distinguish 43 economic sectors. These sectors are defined as classified in the National Accounts for Spain, which corresponds with the NACE/CLIO classification at the 2-digit level. The forecasts are not published in a particular publication, but the forecasts are used and included in various projects.

Sweden

In Sweden several institutes provide short-term forecasts of sectoral employment (The Business Cycle Institute and Federation of Swedish Industries). The Swedish National Board for Industrial and Technical Development provides long term sectoral employment forecasts. The Business Cycle Institute produces medium-term employment forecasts by economic sector, covering a period of 2-3 years, in addition to its short-term forecasts. These quarterly forecasts are published in Business Tendency Forecast. 


\section{United Kingdom}

In the UK the Institute for Employment Research (IER) provides forecasts of employment by economic sector on an annual basis, using the macro-economic model developed by Cambridge Econometrics. The model distinguishes 49 economic sectors, defined in accordance with the standard industrial classification at the 2digit level (for the latest assessment the SIC 1992 was used). For presentational purposes these 49 sectors are aggregated to 17 economic groups. The forecasts cover a medium-term period. The IER's sectoral employment forecasts are published annually, along with other forecasts, in The Review of the Economy and Employment. The sectors which are presented in the Review are:

- Agriculture

- Mining

- Food, drink and tobacco

- Textiles and clothing

- Chemicals

- Metals and mineral products

- Mechanical engineering

- Electrical engineering

- Motor vehicles

- Rest engineering

- Other manufacturing

- Utilities

- Construction

- Retailing

- Hotels and catering

- Rest distribution, hotel etc

- Transport and communications

- Banking and business services

- Professional services

- Other services

- Public admin. and defence

- Health and education services

The remaining EU Member States

Information on the availability of medium-term employment forecasts by economic sector is still missing for the five remaining Member States of the European Union. 


\section{Conclusion}

In order to forecast expansion demand, as described in chapter 2, medium-term employment forecasts by economic sector are required. We investigated the availability of regular medium-term forecasts of sectoral employment for the various EU Member States. Table 3.1 gives an overview of the results. Most Member States have at least one institute which provides medium-term employment forecasts by economic sector on a regular basis for that country. The forecasting period differs from country by country, with a minimum of 2 years. The frequency with which the forecasts are provided also differs between the Member States. In Finland sectoral employment forecasts are provided three times per year, but in some Member States the frequency is much lower. In the Netherlands, for example the mediumterm employment forecasts by economic sector are provided at four-year intervals. However, in most of the EU Member States these forecasts are made once a year. The number of economic sectors distinguished ranges from 5 in Denmark to 43 in Spain. The classification used to determine the economic sectors also differs between the EU Member States, but the standard industrial classification (SIC) is most widely used. This classification is comparable to the NACE/CLIO classification.

Table 3.1

Overview of the availability of medium-term employment forecasts by EU Member State

\begin{tabular}{|c|c|c|c|}
\hline Country & $\begin{array}{l}\text { medium-term } \\
\text { employment } \\
\text { forecasts }\end{array}$ & $\begin{array}{l}\text { number of } \\
\text { economic } \\
\text { sectors }\end{array}$ & $\begin{array}{c}\text { compatible with } \\
\text { NACE-CLIO }\end{array}$ \\
\hline Austria & yes & 13 & yes \\
\hline Belgium & yes & 9 & yes \\
\hline Denmark & yes & 5 & yes \\
\hline Finland & yes & 9 & yes \\
\hline France & yes & 36 & unknown \\
\hline Germany & yes & 14 & no \\
\hline Greece & . no & - & - \\
\hline Ireland & yes & 11 & yes \\
\hline Italy & yes* & 37 & unknown \\
\hline Luxembourg & no & - & - \\
\hline Netherlands & yes & 15 & yes \\
\hline Portugal & unknown & unknown & unknown \\
\hline Spain & yes & 43 & yes \\
\hline Sweden & yes & unknown & unknown \\
\hline United Kingdom & yes & 17 & yes \\
\hline
\end{tabular}

* The manufacturing industry only

On the basis of this investigation of the availability of regular medium-term employment forecasts broken down by economic sector, we can conclude that the possibilities for a decentralized approach are fair. Sectoral employment forecasts are made on a regular basis in many EU Member States. So these existing 
employment forecasts can be used as the starting point for forecasting employment by occupations and types of education. However, since the EURES information system requires forecasts for all Member States of the European Union, the gaps in the available sectoral employment forecasts will have to be filled.

\subsection{Coordinated approaches}

This section will discuss two previous research projects which were intended to generate employment forecasts for the Member States of the European Union. These are studies are based on a coordinated approach, in the sense that the forecasts are Europe-wide and that the structures of the national sub-models have been coordinated. The methodology of employment forecasting developed by the European Economic Research and Advisory Consortium (ERECO) will be described briefly, followed by an outline of the HERMES model which was developed in the 1980s.

ERECO's forecasts by economic sector and EU regions

The ERECO consortium aims to provide disaggregated information on employment developments in the European Union. Their study on "Medium Term Forecasts of Employment by EU Districts and Sectors of Industry" began in December 1992 (for more detail see ERECO, 1994). This study was carried out on behalf of the European Commission, Directorate General for Employment, Industrial relations and Social Affairs (DG V) by ten European labour market research institutes under the coordination of the IFO Institute for Economic Research in Munich. The study provided forecasts of employment by economic sectors, occupational categories and some other qualitative employment features, for all Member States of the EU. The forecasting period was 1991-1997. The forecasting model developed by ERECO is not a purely centralized approach. ERECO does not use a structured econometric model, which is internationally linked and based on input-output techniques, in its medium-term forecasts. Although this is seen as the ideal approach, lack of time and serious doubts about the significance of such a model and the handling of its complexity led ERECO to follow a 'bottom-up-top-down approach'.

In the bottom-up approach, the required data is derived from various sources, most of it from EUROSTAT. The EUROSTAT data was supplemented with national data. The bottom-up approach was complemented with a top-down procedure which made it possible to obtain consistency on the national and the European level. The forecasts of production and of employment by economic sector and occupation were provided on the national level using nationally developed forecasting models. At the European level, consistency was achieved by fixing common assumptions for 
the exogenous variables of the national models, adjusting the interim results of the national models and adjusting the sectoral assumptions.

Figure 3.1 gives an overview of the different modules which provide the employment forecasts for the Member States of the EU. In the first module the production (value added in constant prices) is forecast and broken down for 25 economic sectors in each of the 12 countries which were then members of the EU. The economic sectors are based on the NACE/CLIO classification at the 2-digit level.

Figure 3.1

General structure of the forecasting model of ERECO

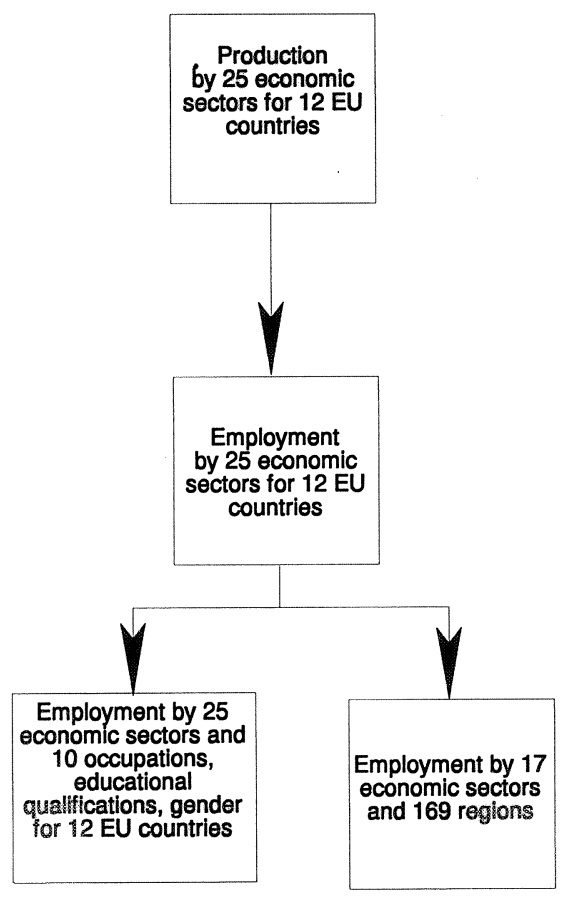

Source: ERECO

In a second module, a forecast of the employment by economic sector was provided for all Member States of the EU on the basis of the forecasts of sectoral production. The employment forecasts by economic sector were quantified in terms of the number of persons employed and the total hours worked. National econometric models were used to provide these forecasts. The labour input, i.e. the total hours worked, was estimated as a function of real output, labour costs and technical change. The theoretical framework for this was similar in all national models, with a few changes. 
ERECO also forecast regional employment by economic sector, based on the sectoral forecasts of employment (second module)..$^{15}$ In this case 17 economic sectors (NACE/CLIO) and 169 regions were distinguished. These regions are grouped according to the EUROSTAT NUTS 2 classification. Once again EUROSTAT provided most of the data for this module (from the EUROSTAT REGIO data base). In addition to the European Regional Economic Model (EREMOD), developed by Cambridge Econometrics, a cross-sectional model was estimated for each economic sector.

\section{The HERMES model}

In 1981, the HERMES ${ }^{16}$ project was started, on the initiative of the Commission of the European Communities (DG XII: Directorate General for Science, Research and Development). Its purpose was to develop a European (dynamic) macrosectoral model (Commission of the European Communities, 1993). The HERMES model consists of medium-term, macroeconomic models, interlinked by a bilateral flow module with regard to the relationships between the economies of the various Member States. HERMES is a 'neo-Keynesian' demand-oriented model, but supplyside elements were also incorporated. The model permits in-depth analysis of productivity, employment and energy requirements, among others things.

The HERMES model includes a national model for each of the 12 Member State in the European Union at that time, and 12 institutes collaborated in its development. Simplified models for other OECD areas and the rest of the world were added to the models of the Member States. HERMES does not link existing national models: the national teams developed their models using the same structure, based on a standard model developed for this purpose (d'Alcantara and Italianer, 1982), and harmonised data. So despite the decentralized execution of the project, the national teams respected compatibility requirements. Nevertheless, it was not possible to prevent some national differences.

Each national model consisted of a macroeconometric sectoral model and an energy sub-model. Energy plays a special role as a factor of production in the HERMES models. The HERMES models have been used for research in very diverse fields, which indicates the wide-ranging capabilities of the model. For example, at the multinational level the consequences of oil price decreases and the consequences of reduction or reorganisation of working hours were investigated.

15. In addition to these regional forecasts, ERECO also transforms the sectoral forecasts into employment forecasts for 10 occupational groups.

16. HERMES is short for Harmonised Economic Model and Energy System. 
Also at this level the national research teams who had developed the national HERMES models are brought together in the HERMES Club. Until recently they provided an annual macrosectoral forecast of the European economy as a whole, covering the medium-term. The HERMES model distinguishes 9 branches, related to the NACE/CLIO Code (2-digit). These sectors are :

- Agriculture, forestry and fishery products

- Fuel and power products (energy)

- Intermediate goods (manufacturing)

- Capital equipment (manufacturing)

- Consumer goods (manufacturing)

- Building and construction

- Transport and communication

- Other market services

- Non-market services

Although the HERMES model was not initially created to provide medium-term forecasts of employment by economic sector, the model can be used for this purpose. The MASTER ${ }^{17}$ model, which is related to HERMES (see Jansen et al., 1994), is used to analyze the heterogeneity of employment and the role of technical change. The general structure of MASTER resembles the HERMES structure closely. MASTER is composed of an input-output block, a production module and a Skill Allocation Module: SAM. To model technological change, MASTER uses a putty-semi-putty vintage model, in which the scrapping of old vintages of capital goods follows explicitly from decisions taken by entrepreneurs. In the SAM module the demand for labour is translated into employment by sector of industry in terms of skills, in a way which is consistent with the available supply of skills.

At the moment the HERMES model is no longer applied for forecasting employment at European level.

\section{Conclusion}

This section discussed two previous research projects which followed a coordinated approach. Both these projects provided employment forecasts for all Member States of the European Union, although the HERMES model was not initially created to provide employment forecasts. Although both the ERECO and HERMES research projects used national models, they did not build on the cardinal macro-economic and sectoral forecasts imbedded in the national public policies in the various Mem-

17. MASTER stands for Model for the Analysis of Sectoral Technology and Employment Relations. 
ber States. It would not be practible for the EURES system to be independent of the existing national forecasts, since the EURES forecasts would then differ from the national forecasts and would not be usable at a national level. Therefore, a coordinated approach to producing the required sectoral labour market forecasts should be supplementary to the existing national forecasts, and should aim only at filling the gaps between the available and required labour market information. 


\section{Availability of data for occupational and educational forecasts}

\subsection{The required data}

\section{Expansion demand by occupation}

As described in Chapter 2, 8 modules can be distinguished within the proposed forecasting model. Module I refers to the expansion demand by economic sector. For this module the sectoral forecasts described in Chapter 3 are of crucial importance as these forecasts are the basis of the expansion demand forecasts by both occupations and educational qualifications. Since most economic sectors offer employment to a broad spectrum of occupations, it is important to determine which occupations will profit from the expected expansion demand within an economic sector. For this reason, in the second step (module II) expansion demand by economic sector is translated into the expansion demand by occupation. The sum of the predicted employment growth for an occupation in all economic sectors yields the expected expansion demand for that particular occupation. In translating the employment forecasts per economic sector into employment forecasts by occupation, two components play an essential role: changes in the employment levels per economic sector ('the sectoral effect') and changes in the occupational structure of employment within each economic sector (the occupational effect).

To calculate the expansion demand by occupation, it is necessary to have data on sector $x$ occupation matrices, preferably over a period of some years. If analyses and forecasts are to be reliable, the number of workers in a particular occupation must not be too small. As a rule of thumb we suggest that, in calculating expansion demand by occupation the occupational categories to be distinguished should employ more than 5,000 persons at the national level, as this is the level on which the forecasts of changes in the occupational shares in the various economic sectors are based. At the regional level the occupations to be distinguished should employ more than 2,000 persons, in order to provide a reliable basis on which the estimated national shifts in the occupational structure of employment in a particular economic sector can be projected.

Expansion demand by educational qualification

The demand from employers arises primarily from the need to have some particular tasks or jobs carried out. However, the supply of labour is characterized mainly by the educational background of the workers. If a confrontation of demand and supply 
is to be made, the forecasts of demand by occupational class must therefore be transformed into forecasts by type of education. ${ }^{18}$

For this reason expansion demand by occupation is translated, in module IV, into expansion demand by educational qualification. There is in general no single type of education which is uniquely appropriate for a particular occupation. De Grip and Heijke (1991) show that it is important to recognize that people from several different types of education may be eligible for an occupation. The problem therefore arises, that the demand for labour in a given occupation may be assigned to several educational qualifications, but only one person with one particular background can be hired to fill each job. In fact people with a particular educational qualification are generally in demand in several occupations, but are in competition in these occupations with workers with different educational backgrounds. This problem can be resolved by predicting the educational structure of occupations on the basis of their structure in the past. This requires a time series of occupation $x$ educational qualification matrices. To produce reliable forecasts we again formulate as a rule of thumb that the educational qualifications to be distinguished should employ more than 5,000 persons at the national level, and that at the regional level all the educational categories distinguished should employ more than 2,000 workers.

Replacement demand by occupation and educational qualification

However, as mentioned in Chapter'2, expansion demand is not the only relevant component of demand. Replacement demand (modules III and V) is also very important, as this variable determines the vacant jobs due to the mobility between occupations and the flows out of the labour market.

The replacement demand forecasts will be based on the cohort change rates of the people working within each occupation. The replacement demand by occupation forecasts require an occupation $x$ sex $x 5$ years age group matrix for at least two years. The replacement demand by educational qualification is calculated using the same method as was described for the replacement demand by occupation. These forecasts require a type of education $x$ sex $x$ 5-year age group matrix for at least two years.

18. An alternative would be to transfer the forecasts of supply by educational qualification into the supply by occupation. 
Supply by educational qualification

Employment forecasts are not sufficient to determine the chances of a person with a particular educational background getting a job in a certain occupation in a certain region. An individual also needs to know how many people will be competing for the job. Competition for jobs will come mainly from school-leavers in the region itself and the surrounding regions. The forecasts of school-leavers by type of education (module $\mathrm{VI}$ ) require data on the number of students per type of education by school year and sex, transition matrices on the flows within initial education by sex, and data on the participation in additional training by type of education and initial educational qualification.

Supply of unemployed

As mentioned in Chapter 2, the forecast of the number of school-leavers should be supplemented with the number of short-term unemployed workers, who will compete for the available jobs (module VII). Only the short-term unemployed are important, since the knowledge and skills of people who have been unemployed for a very long time become more or less obsolete. It is important to know what kind of educational background the short-term unemployed have, as an indication of which school-leavers they will compete with. This module requires recent data on the short-term unemployed by educational qualification.

Overview of the data required

To conclude this section, Table 4.1 shows the required data matrices for all modules of the labour market forecasting model. 


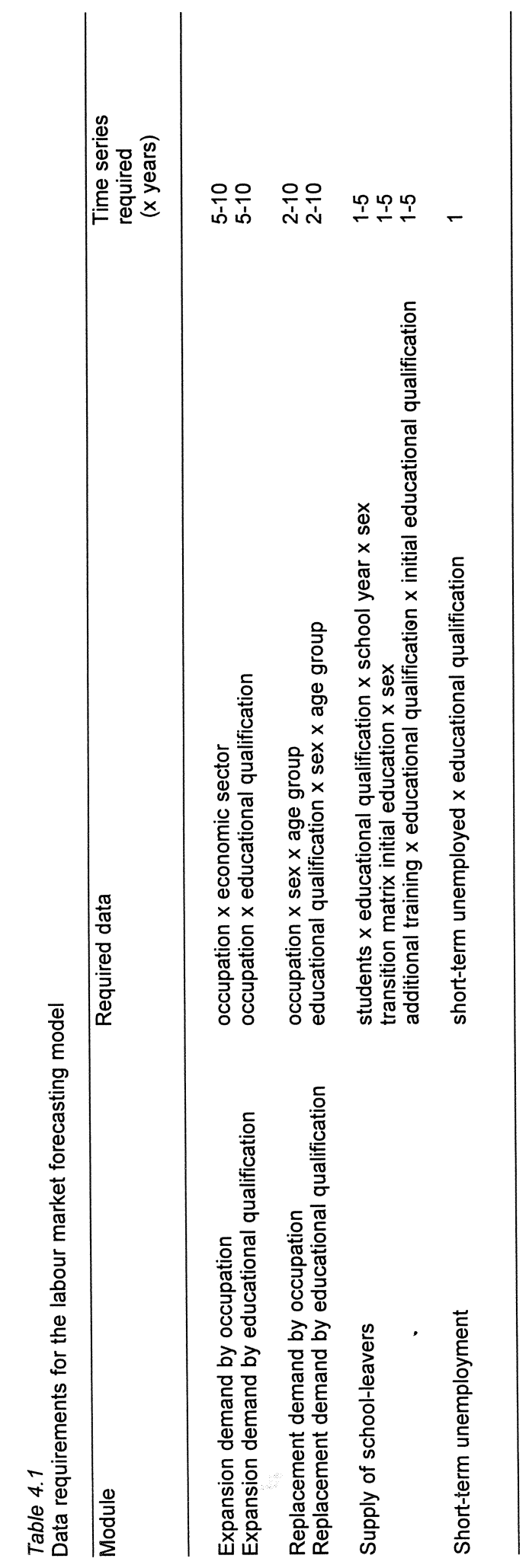




\subsection{Data availability at the European level}

The main source of data available at the European level is the Labour Force Survey (LFS) of EUROSTAT. Within the Labour Force Survey, survey data from all Member States of the European Union is combined in variables which are comparable with regard to several characteristics of the labour force. This section will analyze whether EUROSTAT'S LFS data is of sufficient quality for making labour market forecasts at the regional level. As of 1993, data is available for 12 Member States. No data is yet available for the new Member States (Austria, Finland and Sweden). The Labour Force Survey contains information on 60 economic sectors, 111 occupations and 246 regions (see also Appendix C).

Within the Labour Force Survey, 60 economic sectors can be distinguished according to the Statistical Classification of Economic Activities (NACE) reverence 1, 2digit level. However we will consider only the 17 sectors at the 1-digit NACE level. The 111 occupations are based on the International Standard Classification of Occupations 1988 (ISCO'88) on the 3-digit level. The occupations can be aggregated into 27 occupational classes (2-digit) and 10 occupational sectors (1-digit). The regions distinguished in the Member States are based on the Nomenclature of Territorial Unites (NUTS) at the 2-digit level, except that the Italian regions have been aggregated from 96 to 20 regions.

In some cases the regions based on the NUTS classification at the 2-digit level have been adjusted to match the regional classification used in the EURES information system. ${ }^{19}$ The result is that the 12 NUTS- 2 regions in Belgium have been aggregated into 3 regions, and the 41 NUTS-2 regions in Germany into 16 regions. The EURES regions for some countries are at a lower level of aggregation than the NUTS-2 regions. For instance, EURES subdivides the Irish NUTS-2 region 'East' in into 3 regions, and distinguishes various regions within Denmark based on the NUTS 3-digit level, whereas there are no regions within Denmark at the NUTS-2 level. ${ }^{20}$ In such cases we have not the NUTS-2 regions to the level of the EURES system. The Labour Force Survey also contains information with regard to age and

19. But Ceuta and Mellila (Spain), Poutou-Charentes and Aquitaine (France) and Madeira (Portugal), which are not presented in the EURES information system, are included in the analysis in this chapter.

20. The result of these adjustments is that the number of regions distinguished in each country is as follows: Belgium 3, Denmark 1, Germany 16, Greece 13, Spain 18, France 22, Ireland 8 , Italy 20 (was 96), Luxembourg 1, Netherlands 12, Portugal 7 and the United Kingdom 11, giving a total of 132 regions. If the analysis was made on the 1-digit level, the number of regions would be reduced to 69 . 
sex. The number of households in the sample and, where possible, the sample size are described in table 4.2

Table 4.2

Sample size of the LFS in the various EU Member States

\begin{tabular}{lrc}
\hline Country & Number of households & $\begin{array}{c}\text { Sample size } \\
\%\end{array}$ \\
\hline Belgium & 35,000 & 0.95 \\
Denmark & 19,000 & 1.60 \\
Germany & 100,000 & 0.40 \\
Greece & 47,000 & 1.50 \\
Spain & 62,000 & - \\
France & 65,000 & -33 \\
Ireland & 45,000 & - \\
Italy & 123,000 & - \\
Luxembourg & 10,000 & 7.81 \\
Netherlands & 30,000 & 1.00 \\
Portugal & 35,000 & - \\
United Kingdom & 85,000 & \\
\end{tabular}

Source: EUROSTAT, 1988

The nature of the Labour Force Survey entails a number of problems with regard to various modules of the forecasting model. The main problem is that educational qualifications can, at present, hardly be distinguished. At the best, 9 educational classes could be distinguished in the data from the Labour Force Survey, but EUROSTAT's present position is that it would be wiser to distinguish only 3 educational levels, related to the ISCED 1-digit classification. These three levels are Low (ISCED 0/1/2), Medium (ISCED 3) and High (ISCED 5/6/7). It is not expected to be possible to distinguish more types of education within the Labour Force Survey in the near future. This means that modules IV to VIII cannot be calculated at the moment on the basis of the EUROSTAT LFS data, since replacement demand and expansion demand on only three levels of education would not give useful results for forecasting job opportunities by educational background. At the moment the OECD work group INES is developing a more extensive system of comparable types of education for its Member States. At the moment it is unclear what the outcome of this will be.

The EUROSTAT data restricts the labour market information that can be generated in addition to the sectoral forecasts to occupational information, i.e. to modules II and III. ${ }^{21}$ At the moment the available data would enable us only to make crude forecasts of expansion demand by occupation. The problems that arise here are the

21. For this reason we have also not investigated the availability of the required labour supply data by type of education from other data sources. 
limited time series due to the transition from ISCO'68 to ISCO' 88 and from NACE to NACE rev.1, problems arising from Member States' unwillingness to adapt to the new standards ${ }^{22}$ and definition problems. ${ }^{23}$ The result of this transition is that data is only available for 1993 and 1994, whereas a time series of at least five years would be preferred. However, it will probably be possible to obtain an adequate time series in the near future, which could increase the quality of the results of the forecasting model. As was said in section 2.2, we propose estimating the model of shifts in the occupational structure of employment using national data, and to project these shifts onto actual data of the occupational structure of employment in the various economic sectors. For this reason the occupations to be distinguished at the national level should employ more than 5,000 workers, whereas those distinguished at the regional level should employ more than 2,000 workers.

Analyses of EUROSTAT's LFS data show that most cells contain sufficiently large numbers of workers at the national level for the forecast calculations. It is however remarkable that no country distinguishes all 111 occupations which can be distinguished at the ISCO' 88 3-digit level. Table 4.3 presents the total working population, the number of occupations with more than 5,000 employed persons and the number of occupations distinguished in the various Member States. In most of the Member States, between 104 and 106 from the 111 3-digit occupations are distinguished. In France only 95 occupations are differentiated. As mentioned before, the 55 occupations in Ireland are the result of the conversion of the available Irish Labour Force Survey data from ISCO'68 to ISCO'88. Leaving Luxembourg and Ireland aside, the number of occupations with more than 5,000 employed persons ranges from 76 in Greece to 103 in Germany. Since Luxembourg has a small population, it is not surprising that there are only a few occupations which exceed the threshold value of 5,000 workers.

22. Germany has not yet implemented the NACE rev. 1, so EUROSTAT itself has converted the German NACE data to the NACE rev. 1 standard. EUROSTAT is not convinced that this conversion is perfect. The conversion to the new economic sector of 'Wholesale and retail trade; repair of motor vehicles, motorcycles and personal and household goods' has caused especially large problems. EUROSTAT therefore advises great caution in interpreting the German sectoral data. Since Ireland had not implemented ISCO' 88 yet, EUROSTAT has converted Ireland's ISCO' 68 data to ISCO' 88 , which leads to a total of only 55 occupations. For this reason the Irish data is not comparable with the other EU Member States.

23. In most countries independent farmers are classified as 'Skilled agricultural workers' (ISCED 6), whereas in France they are classified as 'Managers of small enterprises' (ISCED 1). 
Table 4.3

Data availability for the European Union: occupations with more than 5,000 employed persons, 1994

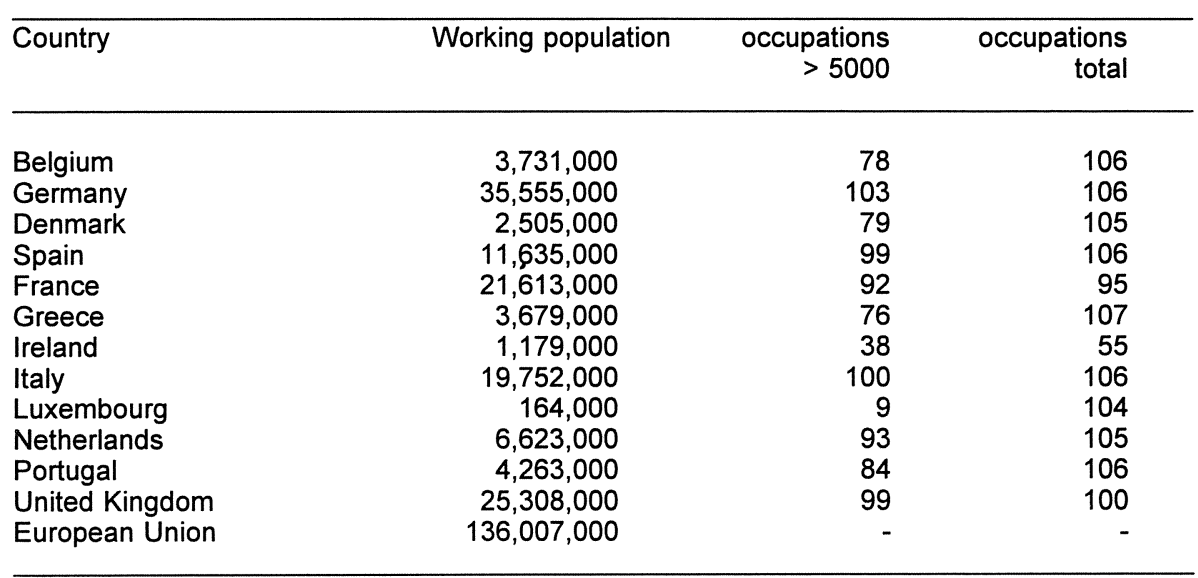

Source: EUROSTAT, LFS

Table 4.4 gives an overview of the data availability at regional level. The table shows the working population and the number of occupations which exceed the threshold value for regional data, i.e. those with more than 2,000 workers. The table also shows that a reasonable number of occupations can be distinguished at the regional level using EUROSTAT's Labour Force Survey data. In the various regions in Belgium, Germany, Spain, France, Italy, the Netherlands and the United Kingdom there are relatively many occupations with more than 2,000 workers, although there are some regions even in these countries with just a few occupations containing more than 2,000 employed persons. For instance, Rioja (Spain) has just 11; Corse (France), 9; Valle d'Aosta (Italy), 4 and Flevoland (Netherlands), 21. The number of occupations containing more than 2,000 workers is, in general, much smaller in the regions of Greece, Ireland and Portugal. Over Europe as a whole, the number of occupations with more than 2,000 workers ranges from 4 in Valle d'Aosta (Italy) to 95 in South East (United Kingdom). 
Table 4.4

Data availability for the European Union: number of occupations with more than 2,000 employed persons in 1994

\begin{tabular}{|c|c|c|}
\hline Region & Working population & $\begin{array}{r}\text { occupations } \\
>2,000\end{array}$ \\
\hline \multicolumn{3}{|l|}{ Belgium ${ }^{*}$} \\
\hline Vlaams Gewest & $2,283,000$ & 87 \\
\hline Région Wallonne & $1,127,000$ & 62 \\
\hline Brussel & 321,000 & 41 \\
\hline \multicolumn{3}{|l|}{ Germany } \\
\hline Schleswig-Holstein & $1,203,000$ & 70 \\
\hline Hamburg & 780,000 & 66 \\
\hline Niedersachsen & $3,307,000$ & 86 \\
\hline Bremen & 282,000 & 42 \\
\hline Nordrhein-Westfalen & $7,314,000$ & 97 \\
\hline Hessen & $2,640,000$ & 90 \\
\hline Rheinland-Pfalz & $1,681,000$ & 87 \\
\hline Baden-WÖrtenberg & $4,652,000$ & 94 \\
\hline Bayern & $5,666,000$ & 96 \\
\hline Saarland & 415,000 & 49 \\
\hline Berlin & $1,603,000$ & 79 \\
\hline Brandenburg & $1,086,000$ & 75 \\
\hline Mecklenburg-Vorpommern & 784,000 & 63 \\
\hline Sachsen & $1,888,000$ & 81 \\
\hline Sachsen-Anhalt & $1,160,000$ & 68 \\
\hline Thuringen & $1,095,000$ & 73 \\
\hline \multicolumn{3}{|l|}{ Denmark } \\
\hline & & \\
\hline \multicolumn{3}{|l|}{ Spain } \\
\hline Galicia & 891,000 & 59 \\
\hline Asturias & 308,000 & 39 \\
\hline Cantabria & 150,000 & 21 \\
\hline Pais Vasco & 657,000 & 66 \\
\hline Navarra & 173,000 & 29 \\
\hline Rioja & 81,000 & 11 \\
\hline Aragon & 384,000 & 45 \\
\hline Madrid & $1,542,000$ & 81 \\
\hline Castilla-Leon & 758,000 & 60 \\
\hline Castilla-La Mancha & 476,000 & 43 \\
\hline Extremadura & 270,000 & 29 \\
\hline Cataluna & $2,038,000$ & 85 \\
\hline Cummunidad Valenciana & $1,200,000$ & 71 \\
\hline Baleares & 243,000 & 29 \\
\hline Andalucia & $1,688,000$ & 76 \\
\hline Murcia & 311,000 & 36 \\
\hline Ceuta y Melilla*** & 30,000 & 3 \\
\hline Canarias & 434,000 & 41 \\
\hline \multicolumn{3}{|l|}{ France } \\
\hline lle de France & $4,628,000$ & 85 \\
\hline Champagne-Ardenne & 465,000 & 52 \\
\hline Picardie & 609,000 & 59 \\
\hline Haute-Normandie & 640,000 & 59 \\
\hline Centre & 908,000 & 66 \\
\hline Basse-Normandie & 463,000 & 50 \\
\hline
\end{tabular}


Table 4.4 (continued)

Data availability for the European Union: number of occupations with more than 2,000 employed persons in 1994

\begin{tabular}{|c|c|c|}
\hline Region & - Working population & $\begin{array}{r}\text { occupations } \\
>2,000\end{array}$ \\
\hline $\begin{array}{l}\text { Bourgogne } \\
\text { Nord-Pas-de-Calais } \\
\text { Lorraine } \\
\text { Alsace } \\
\text { France-Comite } \\
\text { Pays de la Loire } \\
\text { Bretagne } \\
\text { Potou-Charentes }{ }^{\star \star \star} \\
\text { Aquitaine } \\
\text { Midi-Pyrenees } \\
\text { Limousin } \\
\text { Rhone-Alpes } \\
\text { Auvergne } \\
\text { Languedoc-Rousillon } \\
\text { Provence-Alpes-Cote d Azur } \\
\text { Corse }\end{array}$ & $\begin{array}{r}608,000 \\
1,247,000 \\
861,000 \\
661,000 \\
424,000 \\
1,222,000 \\
1,104,000 \\
587,000 \\
1,040,000 \\
899,000 \\
249,000 \\
2,259,000 \\
462,000 \\
744,000 \\
1,463,000 \\
71,000\end{array}$ & $\begin{array}{r}57 \\
66 \\
67 \\
58 \\
55 \\
68 \\
64 \\
55 \\
66 \\
62 \\
37 \\
76 \\
50 \\
63 \\
73 \\
9\end{array}$ \\
\hline $\begin{array}{l}\text { Greece } \\
\text { Anatoliki Makedonia, Thraki } \\
\text { Kentriki Makedonia } \\
\text { Dytiki Makedonia } \\
\text { Thessalia } \\
\text { Ipeiros } \\
\text { lonia Nisia } \\
\text { Dytiki Ellada } \\
\text { Sterea Ellada } \\
\text { Peloponnisos } \\
\text { Attiki } \\
\text { Voreio Aigaio } \\
\text { Notio Aigaio } \\
\text { Kriti }\end{array}$ & $\begin{array}{r}226,000 \\
644,000 \\
105,000 \\
249,000 \\
98,000 \\
73,000 \\
217,000 \\
156,000 \\
202,000 \\
1,360,000 \\
50,000 \\
99,000 \\
200,000\end{array}$ & $\begin{array}{r}25 \\
55 \\
13 \\
26 \\
13 \\
9 \\
20 \\
17 \\
15 \\
73 \\
6 \\
9 \\
16\end{array}$ \\
\hline $\begin{array}{l}\text { Ireland } \\
\text { East } \\
\text { South West } \\
\text { South East } \\
\text { North East } \\
\text { Mid-West } \\
\text { North West and Donegal } \\
\text { Midlands } \\
\text { West }\end{array}$ & $\begin{array}{r}496,000 \\
172,000 \\
115,000 \\
64,000 \\
100,000 \\
61,000 \\
79,000 \\
92,000\end{array}$ & $\begin{array}{l}37 \\
25 \\
19 \\
12 \\
17 \\
11 \\
13 \\
16\end{array}$ \\
\hline $\begin{array}{l}\text { Italy } \\
\text { Piemonte } \\
\text { Valle d'Aosta } \\
\text { Liguria } \\
\text { Lomdardia } \\
\text { Trentino-Alto Adige } \\
\text { Veneto } \\
\text { Fruiti-Venezia Giulia } \\
\text { Emilia-Romagna } \\
\text { Toscana } \\
\text { Umbria }\end{array}$ & $\begin{array}{r}1,647,000 \\
50,000 \\
561,000 \\
3,618,000 \\
376,000 \\
1,750,000 \\
447,000 \\
1,631,000 \\
1,340,000 \\
288,000\end{array}$ & $\begin{array}{r}72 \\
4 \\
58 \\
88 \\
46 \\
78 \\
47 \\
77 \\
77 \\
38\end{array}$ \\
\hline
\end{tabular}


Table 4.4 (continued)

Data availability for the European Union: number of occupations with more than 2,000 employed persons in 1994

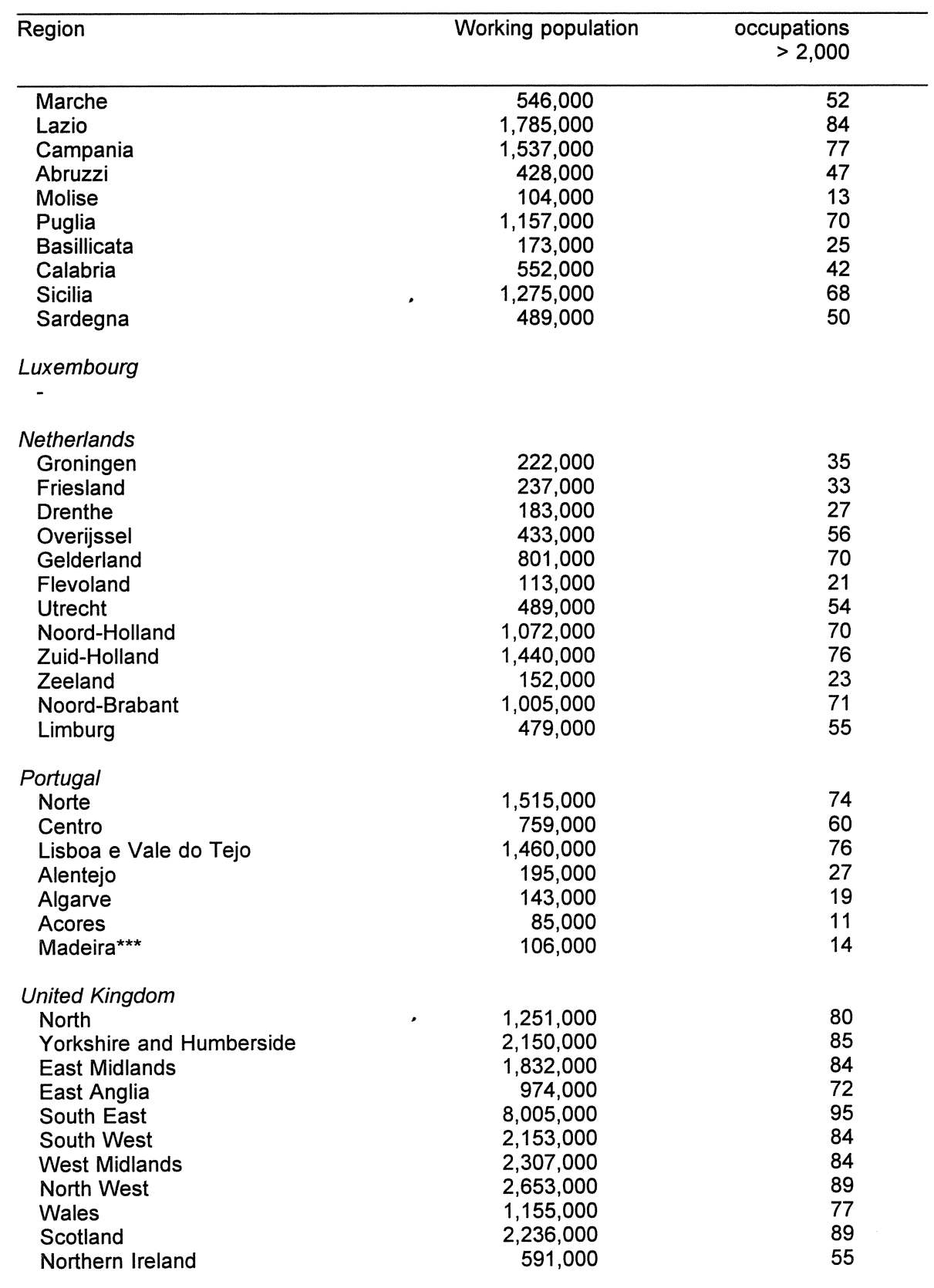

Source: EUROSTAT, LFS

* NUTS 1-digit level; ${ }^{* *}$ Bundesländer; $\quad{ }^{* * *}$ Not distinguished in the EURES Database;

${ }_{* \star \star \star}$ In the EURES Database this region is subdivided into three regions 
The fact that no country distinguishes all 111 occupations found at the ISCO'88 3digit level could well indicate that there are systematic differences in the way the various occupations are classified in the various Member States. Table 4.5 gives an overview of the 3-digit occupations which are not distinguished, not coded or do not occur in a particular Member State. The table does in fact indicate that there are some systematic differences in the way occupations are classified in the various Member States. For example, agricultural, fishery and related labourers certainly will occur in France. Moreover, the table shows the serious drawbacks of the transformation of the ISCO'68 data for Ireland into ISCO' 88 occupational categories. However, it is probable that some of these occupations simply do not occur in a particular country: e.g. shoe cleaning and other street services, etc.

It is remarkable that in most countries several occupations relating to nursing and education are not distinguished or do not occur, and that industrial robot operators and religious associate professionals are also missing in many Member States. 
Table 4.5

Occupations not distinguished, not coded or not occuring per Member State of the EU, 1994

Missing occupations per country

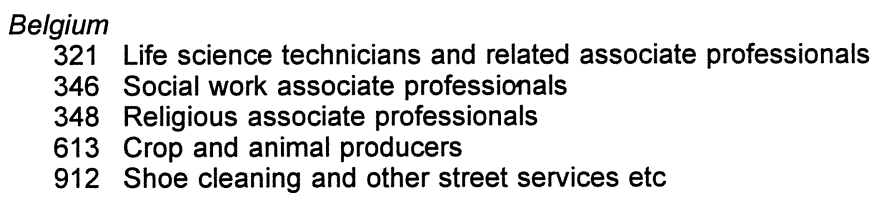

\section{Germany}

223 Nursing and midwifery professionals

331 Primary education teaching associate professionals

613 Crop and animal producers

817 Industrial robot operators

912 Shoe cleaning and other street services etc

\section{Denmark}

212 Mathematicians, statisticians and related professionals

348 Religious associate.professionals

521 Fashion and other models

744 Pelt, leather and shoemaking trades workers

817 Industrial robot operators

912 Shoe cleaning and other street services etc

Spain

323 Nursery and midwifery associate professionals

331 Primary education teaching associate professionals

332 Pre-primary education teaching associate professionals

333 Special education teaching associate professionals

011 Armed forces

\section{France}

114 Senior officials of special-interest organisations

212 Mathematicians, statisticians and related professionals

223 Nursing and midwifery professionals

233 Primary and pre-primary education teaching professionals

234 Special education teaching professionals

315 Safety and quality inspectors

332 Pre-primary education teaching associate professionals

521 Fashion and other models

733 Handicraft workers in wood, textile, leather and related materials

817 Industrial robot operators

823 Rubber- and plastic-products machine operators

911 Street vendors and related workers

912 Shoe cleaning and other street services etc

914 Building caretakers, window and related cleaners

921 Agricultural, fishery and related labourers

011 Armed forces

Greece

333 Special education teaching associate professionals

334 Other teaching associate professionals

348 Religious associate professionals

817 Industrial robot operators 
Table 4.5 (continued)

Occupations not distinguished, not coded or not occuring per Member State of the EU, 1994

Missing occupations per country

Ireland

114 Senior officials of special-interest organisations

121 Directors and chief executives

122 Production and operations managers

211 Physicists, chemists and related professionals

213 Computing professionals

221 Life science professionals

223 Nursing and midwifery professionals

231 College, university and higher education teaching professionals

232 Secondary education teaching professionals

233 Primary and pre-primary education teaching professionals

234 Special education teaching professionals

243 Archivists, librarians and related information professionals

244 Social science and related professionals

247 Public service administrative professionals

312 Computer associate professionals

313 Optical and electronic equipment operators

315 Safety and quality inspectors

322 Health associate professionals (except nursing)

323 Nursery and midwifery associate professionals

331 Primary education teaching associate professionals

333 Special education teaching associate professionals

334 Other teaching associate professionals

342 Business services agents and trade brokers

343 Administrative associate professionals

344 Customs, tax and related government associate professionals

345 Police inspectors and detectives

346 Social work associate professionals

348 Religious associate professionals

412 Numerical clerks

422 Client information clerks

511 Travel attendants and related workers

513 Personal care and related workers

521 Fashion and other models

612 Animal producers and related workers

613 Crop and animal producers

713 Building finishers and related trades workers

723 Machinery mechanics and fitters

733 Handicraft workers in wood, textile, leather and related materials

734 Craft printing and related trades workers

812 Metal-processing plant operators

813 Glass, ceramics and related plant operators

816 Power-production and related plant operators

817 Industrial robot operators

821 Metal- and mineral-products máchine operators

822 Chemical-products machine operators

824 Wood-products machine operators

826 Textile-, fur- and leather-products machine operators

827 Food and related products machine operators

832 Motor vehicle drivers

833 Agricultural and other mobile plant operators

834 Ships deck crews and related workers

911 Street vendors and related workers

912 Shoe cleaning and other street services etc 
Table 4.5 (continued)

Occupations not distinguished, not coded or not occuring per Member State of the EU, 1994

Missing occupations per country

915 Messengers, porters, doorkeepers etc

916 Garbage collectors and related labourers

932 Manufacturing labourers

Italy

123 Other specialist managers

223 Nursing and midwifery professionals

331 Primary education teaching associate professionals

332 Pre-primary education teaching associate professionals

829 Other machine operators n.e.c.

\section{Luxembourg}

521 Fashion and other models

612 Animal producers and related workers

613 Crop and animal producers

615 Fishery workers, hunters and trappers

733 Handicraft workers in wood, textile, leather and related materials

817 Industrial robot operators

912 Shoe cleaning and other street services etc

Netherlands

331 Primary education teaching associate professionals

332 Pre-primary education teaching associate professionals

333 Special education teaching associate professionals

733 Handicraft workers etc

817 Industrial robot operators

912 Shoe cleaning and other street services etc

\section{Portugal}

212 Mathematicians, statisticians and related professionals

223 Nursing and midwifery professionals

233 Primary and pre-primary education teaching professionals

333 Special education teaching associate professionals

348 Religious associate professionals

\section{United Kingdom}

312 Computer associate professionals

321 Life science technicians and related associate professionals

331 Primary education teaching associate professionals

333 Special education teaching associate professionals

348 Religious associate professionals

521 Fashion and other models

612 Animal producers and related workers

817 Industrial robot operators

829 Other machine operators n.e.c.

912 Shoe cleaning and other street services etc

011 Armed forces 
Table 4.6

3-digit occupations that do not occur in the Labour Force Survey of the various Member States of the EU, 1994

\begin{tabular}{|c|c|}
\hline Country and occupational code & Number of workers \\
\hline \multicolumn{2}{|l|}{ Belgium } \\
\hline 329 & 200 \\
\hline 998 & 3,200 \\
\hline \multicolumn{2}{|l|}{ Germany } \\
\hline 120 & 181,900 \\
\hline 130 & 302,400 \\
\hline 610 & 354,400 \\
\hline 999 & $1,039,700$ \\
\hline \multicolumn{2}{|l|}{ Denmark } \\
\hline 120 & 400 \\
\hline 420 & 300 \\
\hline 799 & 10,500 \\
\hline 899 & 1,000 \\
\hline 998 & 100 \\
\hline 999 & 19,000 \\
\hline \multicolumn{2}{|l|}{ Spain } \\
\hline 010 & 35,300 \\
\hline 330 & 6,000 \\
\hline \multicolumn{2}{|l|}{ France } \\
\hline 010 & 301,200 \\
\hline 729 & 91,900 \\
\hline 799 & 12,000 \\
\hline 998 & 62,400 \\
\hline \multicolumn{2}{|l|}{ Greece } \\
\hline \multirow{2}{*}{\multicolumn{2}{|c|}{ Ireland }} \\
\hline & \\
\hline 998 & 4,300 \\
\hline \multicolumn{2}{|l|}{ Italy } \\
\hline 998 & 639,700 \\
\hline \multicolumn{2}{|l|}{ Luxembourg } \\
\hline 299 & 600 \\
\hline 998 & 100 \\
\hline \multicolumn{2}{|l|}{ Netherlands } \\
\hline 230 & 1,600 \\
\hline 410 & 36,900 \\
\hline 799 & 300 \\
\hline 820 & 4,600 \\
\hline 899 & 1,300 \\
\hline 998 & 231,600 \\
\hline 999 & 18,200 \\
\hline \multicolumn{2}{|l|}{ Portugal } \\
\hline 299 & 400 \\
\hline 799 & 38,000 \\
\hline 899 & 12,300 \\
\hline 999 & 15,000 \\
\hline \multicolumn{2}{|l|}{ United Kingdom } \\
\hline 010 & 117,000 \\
\hline 998 & 164,400 \\
\hline
\end{tabular}

Source: EUROSTAT, LFS

Table 4.6 shows the 3-digit occupations that do not occur in the Labour Force Survey of the various Member States of the EU and the total number of workers in 
these occupations. The codes 998 and 999 are most likely workers of which the occupation is unknown. The table shows that in particular in Germany and Italy for a large group of workers the occupation is unknown.

It may well be worthwhile to include information on the largest occupational groups in the various EU regions in the EURES system. Table 4.7 presents the occupations with the largest number of employed persons in the various Member States. In Belgium the number of workers is largest for other office clerks, managers of small enterprises and secondary education teaching professionals. In Germany the occupations with the largest number of workers are other office clerks, shop, stall and market salespersons etc. and administrative associate professionals. The other office clerks and shop, stall and market salespersons etc. also have a large number of employed persons in Denmark, but it is the personal care and related workers which have the largest number of workers in this Member State. In Spain, managers of small enterprises, domestic and related helpers, cleaners etc. and, again, shop, stall and market salespersons etc. are the occupations with the largest number of workers. In France, numerical clerks, shop, stall and market salespersons and personal care and related workers are the most important occupations with respect to the number of workers. In Greece and Ireland, market gardeners and crop growers, managers of small enterprises, other office clerks and shop, stall and market salespersons etc. have the largest number of employed persons. In Italy the occupations with the largest number of workers are shop, stall and market salespersons etc., secretaries and keyboard-operating clerks and numerical clerks. In Luxembourg, domestic and related helpers, cleaners etc., other office clerks and managers of small enterprises have the largest number of employed persons. In the Netherlands managers of small enterprises, shop, stall and market salespersons etc. and administrative associate professionals are important occupations with respect to the number of workers. This also holds for Portugal, except that market gardeners and crop growers take the place of the administrative workers. Finally, in the United Kingdom production and operational managers, other specialist managers and shop, stall and market salespersons etc. have the largest number of workers.

It can be seen that, in most of the Member States of the EU, the occupation of shop, stall and market salespersons etc. has a large number of workers. Appendix $E$ presents the occupations with the largest number of employed persons in the various regions of the $\mathrm{EU}$, along with the number of persons employed in the ten occupations defined at the 1-digit level in the various EU regions. 
Table 4.7

Occupations with the largest number of employed persons by Member State of the European Union, 1994

\begin{tabular}{|c|c|}
\hline \multicolumn{2}{|l|}{ Belgium } \\
\hline Other office clerks & 376,000 \\
\hline Managers of small enterprises & 171,000 \\
\hline Secondary education teaching professionals & 158,000 \\
\hline Physical and engineering science technicians & 141,000 \\
\hline Shop, stall and market salespersons etc & 130,000 \\
\hline Building frame and related trades workers & 114,000 \\
\hline Transport labourers and freight handlers & 112,000 \\
\hline Nursing and midwifery professionals & 111,000 \\
\hline Building caretakers, window and related cleaners & 110,000 \\
\hline Motor vehicle drivers & 105,000 \\
\hline \multicolumn{2}{|l|}{ Germany } \\
\hline Other office clerks & $2,073,000$ \\
\hline Shop, stall and market salespersons etc & $1,595,000$ \\
\hline Administrative associate professionals & $1,556,000$ \\
\hline Building finishers and related trades workers & $1,429,000$ \\
\hline Physical and engineering science technicians & $1,089,000$ \\
\hline Manufacturing labourers & 977,000 \\
\hline Motor vehicle drivers & 973,000 \\
\hline Architects, engineers and related professionals & 969,000 \\
\hline Machinery mechanics and fitters & 933,000 \\
\hline Finance and sales associate professionals & 851,000 \\
\hline \multicolumn{2}{|l|}{ Denmark } \\
\hline Personal care and related workers & 183,000 \\
\hline Other office clerks & 120,000 \\
\hline Shop, stall and market salespersons etc & 119,000 \\
\hline Domestic and related helpers, cleaners etc & 118,000 \\
\hline Administrative associate professionals. & 82,000 \\
\hline Motor vehicle drivers & 68,000 \\
\hline Finance and sales associate professionals & 67,000 \\
\hline Primary and pre-primary education teaching prof. & 66,000 \\
\hline Crop and animal producers & 65,000 \\
\hline Physical and engineering science technicians & 60,000 \\
\hline \multicolumn{2}{|l|}{ Spain } \\
\hline Managers of small enterprises & 731,000 \\
\hline Domestic and related helpers, cleaners etc & 607,000 \\
\hline Shop, stall and market salespersons etc & 605,000 \\
\hline Motor vehicle drivers & 523,000 \\
\hline Secretaries and keyboard-operating clerks & 506,000 \\
\hline Building frame and related trades workers & 502,000 \\
\hline Housekeeping and restaurant services workers & 466,000 \\
\hline Market gardeners and crop growers & 435,000 \\
\hline Other office clerks & 303,000 \\
\hline Primary and pre-primary education teaching prof. & 284,000 \\
\hline \multirow{2}{*}{\multicolumn{2}{|c|}{ France }} \\
\hline Numerical clerks & \\
\hline Shop, stall and market salespersons etc & $1,137,000$ \\
\hline Personal care and related workers & $1,033,000$ \\
\hline Domestic and related helpers, cleaners etc & 992,000 \\
\hline
\end{tabular}


Table 4.7 (continued)

Occupations with the largest number of employed persons by Member State of the European Union, 1994

Member State

Number of workers

$\begin{array}{ll}\text { Secretaries and keyboard-operating clerks } & 827,000 \\ \text { Business professionals } & 747,000 \\ \text { Finance and sales associate professionals } & 676,000 \\ \text { Physical and engineering science technicians } & 675,000 \\ \text { Motor vehicle drivers } & 593,000 \\ \text { Building frame and related trades workers } & 567,000\end{array}$

\section{Greece}

Market gardeners and crop growers $\quad 561,000$

$\begin{array}{ll}\text { Managers of small enterprises } & 330,000\end{array}$

Shop, stall and market salespersons étc $\quad 197,000$

$\begin{array}{ll}\text { Motor vehicle drivers } & 148,000\end{array}$

Building frame and related trades workers $\quad 127,000$

$\begin{array}{ll}\text { Housekeeping and restaurant services workers } & 110,000\end{array}$

Building finishers and related trades workers $\quad 95,000$

$\begin{array}{ll}\text { Textile, garment and related trades workers } & 95,000\end{array}$

$\begin{array}{lr}\text { Animal producers and related workers } & 93,000\end{array}$

Ireland

92,000

Shop, stall and market salespersons etc $\quad 89,000$

$\begin{array}{ll}\text { Other office clerks } & 85,000 \\ \text { Managers of } & 8900000\end{array}$

Managers of small enterprises $\quad 79,000$

Housekeeping and restaurant services workers $\quad 63,000$

$\begin{array}{ll}\text { Other teaching professionals } & 61,000 \\ \end{array}$

Health professionals (except nursing) $\quad 53,000$

$\begin{array}{ll}\text { Secretaries and keyboard-operating clerks } & 41,000\end{array}$

Electrical and electronic equipment mechanics etc $\quad 39,000$

$\begin{array}{ll}\text { Building frame and related trades workers } & 37,000\end{array}$

Italy

Shop, stall and market salespersons etc

Secretaries and keyboard-operating clerks

$1,564,000$

Numerical clerks

Finance and sales associate professionals

$1,148,000$

805,000

705,000

$\begin{array}{ll}\text { Housekeeping and restaurant services workers } & 662,000\end{array}$

Building frame and related trades workers 638,000

Market gardeners and crop growers $\quad 609,000$

Machinery mechanics and fitters $\quad 569,000$

Physical and engineering science technicians $\quad 547,000$

$\begin{array}{ll}\text { Motor vehicle drivers } & 541,000\end{array}$

Luxembourg

Domestic and related helpers, cleaners etc $\quad 13,000$

$\begin{array}{lr}\text { Other office clerks } & 12,000\end{array}$

Managers of small enterprises $\quad 9,000$

$\begin{array}{ll}\text { Secretaries and keyboard-operating clerks } & 8,000\end{array}$

$\begin{array}{ll}\text { Building frame and related trades workers } & 7,000\end{array}$

$\begin{array}{ll}\text { Administrative associate professionals } & 6,000\end{array}$

$\begin{array}{ll}\text { Shop, stall and market salespersons etc } & 6,000\end{array}$

Housekeeping and restaurant services workers $\quad 5,000$

$\begin{array}{ll}\text { Motor vehicle drivers } & 5,000\end{array}$ 
Table 4.7 (continued)

Occupations with the largest number of employed persons by Member State of the European Union, 1994

\begin{tabular}{lr} 
Member State & Number of workers \\
\hline Market gardeners and crop growers & 5,000 \\
Netherlands & \\
Managers of small enterprises & 407,000 \\
Shop, stall and market salespersons etc & 353,000 \\
Administrative associate professionals & 282,000 \\
Personal care and related workers & 234,000 \\
Production and operations managers & 227,000 \\
Nursery and midwifery associate professionals & 210,000 \\
Domestic and related helpers, cleaners etc & 208,000 \\
Motor vehicle drivers & 179,000 \\
Secondary education teaching professionals & 179,000 \\
Housekeeping and restaurant services workers & 152,000 \\
& \\
Portugal & \\
Managers of small enterprises & 315,000 \\
Market gardeners and crop growers & 301,000 \\
Shop, stall and market salespersons etc & 212,000 \\
Textile, garment and related trades workers & 190,000 \\
Secretaries and keyboard-operating clerks & 157,000 \\
Building frame and related trades workers & 155,000 \\
Housekeeping and restaurant services workers & 147,000 \\
Numerical clerks & 134,000 \\
Secondary education teaching professionals & 110,000 \\
Motor vehicle drivers & 107,000 \\
United Kingdom & \\
Production and operations managers & $1,367,000$ \\
Other specialist managers & $1,312,000$ \\
Shop, stall and market salespersons etc & $1,235,000$ \\
Domestic and related helpers, cleaners etc & 992,000 \\
Other office clerks & 952,000 \\
Secretaries and keyboard-operating clerks & 875,000 \\
Personal care and related workers & 805,000 \\
Housekeeping and restaurant services workers & 781,000 \\
Managers of small enterprises & 694,000 \\
Finance and sales associate professionals & 689,000 \\
& \\
\hline
\end{tabular}

Source: EUROSTAT, LFS

\subsection{Occupational specialization of the EU Member States}

It will be worthwhile the EURES system to include information on the occupations which are over-represented in the each of the EU Member States. For this purpose we have developed an indicator of the occupational specialization. This specialization index is a measure of the relative size of a particular occupation in a particular country as compared to the EU average. Table 4.8 presents the occupations for which the employment share is more than double the EU average for that occupa- 
tion, for each Member State, i.e. those for which the specialization index is greater than $2 .^{24}$

The table shows that in Belgium directors and chief executives, building caretakers, window and related cleaners and transport labourers and freight handlers are relatively important occupations in comparison with the EU average. Germany is relatively specialized in safety and quality inspectors, customs, tax and related government associate professionals, and other machine operators. The occupations of directors and chief executives, wood-products machine operators and ship and aircraft controllers and technicians are relatively important in Denmark. Spain appears to specialize in fishery workers, hunters and trappers and animal producers and related workers. In France business professionals, wood-processing- and papermaking plant operators and printing-, binding- and paper products etc. are relatively important occupations. Greece is particularly specialized in occupations which focus on the primary necessities of life: market gardeners and crop growers, animal producers and related workers and ship and aircraft controllers and technicians. This is to a lesser degree also the case in Italy, which is specialized in pelt, leather and shoemaking trades workers, handicraft workers etc. and legislators and senior government officials. In Luxembourg rubber- and plastic-products machine operators and glass, ceramics and related plant operators and mining and mineralprocessing-plant operators are relatively important occupations. The Netherlands is specialized in wood-products, machine operators, business services agents and trade brokers and social science and related professionals. In Portugal the pelt, leather and shoemaking trades workers, textile, garment and related trades workers and market gardeners and crop growers are relatively important. The United Kingdom is specialized in other specialist managers, production and operations managers and senior officials of special-interests organisations.

The occupational specialization of the various regions of the EU is given in appen$\operatorname{dix} E$.

24. Since the occupational data of the Irish LFS were originally classified by the old ISCO'68 classification, we excluded the Irish occupational data in calculating the average employment share of each occupation in the total European Union. Moreover, as the index focuses on the most extremely overrepresented occupations it is vulnerable for the still existing differences in the occupational procedures in the various Member Stattes. For this reason the indexes should be dealt with carefully and confronted with national expert judgements on the quality of the data until EUROSTAT succeeds in further improving the quality of the occupational data. 
Table 4.8

Occupational specialization of the EU Member States, 1994*

\begin{tabular}{lr}
\hline Member State and occupation & specialization \\
\hline Belgium & \\
Industrial robot operators & 13.5 \\
Fashion and other models & 5. \\
Nursing and midwifery professionals & 4. \\
Directors and chief executives & 4. \\
Building caretakers, window and related cleaners & 3. \\
Special education teaching associate professionals & 3.9 \\
Transport labourers and freight handlers & 3. \\
Armed forces & 2. \\
Other office clerks &
\end{tabular}

\section{Germany}

Religious associate professionals

Pre-primary education teaching associate professionals $\quad 2.8$

Safety and quality inspectors $\quad 2.4$

Customs, tax and related government associate professionals 2.2

Armed forces $\quad 2.2$

Other machine operators n.e.c. $\quad 2.1$

Denmark

Special education teaching associate professionals $\quad 9.6$

Crop and animal producers $\quad 4.6$

Wood-products machine operators 3.4

Directors and chief executives $\quad 3.4$

Ship and aircraft controllers and technicians $\quad 3.0$

Pre-primary education teaching associate professionals 3.0

$\begin{array}{ll}\text { Personal care and related workers } & 2.8\end{array}$

Food and related products machine operators $\quad 2.6$

Blacksmiths, tool-makers and related trades workers 2.6

Primary and pre-primary education teaching professionals 2.3

Ships deck crews and related workers $\quad 2.5$

Travel attendants and related workers 2.3

Other teaching associate professionals $\quad 2.2$

$\begin{array}{ll}\text { Archivists, librarians etc } & 2.1\end{array}$

Spain

Fashion and other models $\quad 7.0$

Fishery workers, hunters and trappers $\quad 3.6$

Animal producers and related workers $\quad 2.9$

Mining and construction labourers $\quad 2.4$

Glass, ceramics and related plant operators $\quad 2.4$

Street vendors and related workers $\quad 2.3$

Managers of small enterprises $\quad 2.2$

Primary and pre-primary education teaching professionals $\quad 2.2$

Industrial robot operators $\quad 2.2$

Agricultural, fishery and related labourers $\quad 2.1$

Garbage collectors and related labourers $\quad 2.1$

Special education teaching professionals

France

Primary education teaching associate professionals 4.8

$\begin{array}{ll}\text { Business professionals } & 4.8 \\ \text { Crop and antalo } & 2.9\end{array}$

Crop and animal producers $\quad 2.9$

Wood-processing- and papermaking-plant operators $\quad 2.6$

Printing-, binding-, and paper-products etc 2.3 
Table 4.8 (continued)

Occupational specialization of the EU Member States, 1994

Member State and occupation

specialization-index

Animal producers and related workers

Public service administrative professionals

2.2

Life science technicians and related associate professionals

2.2

Food and related products machine operators

Assemblers

Greece

Market gardeners and crop growers

Animal producers and related workers

Ship and aircraft controllers and technicians $\quad 4.4$

Other teaching professionals $\quad 3.4$

Armed forces

Ships deck crews and related workers $\quad 3.2$

Managers of small enterprises $\quad 3.1$

Fishery workers, hunters and trappers 2.5

Textile, garment and related trades workers $\quad 2.5$

Mining and mineral-processing-plant operators 2.5

Italy

Pelt, leather and shoemaking trades workers $\quad 3.6$

Handicraft workers etc $\quad 3.2$

$\begin{array}{ll}\text { Industrial robot operators } & 2.8\end{array}$

Legislators and senior government officials $\quad 2.6$

Life science professionals $\quad 2.4$

Special education teaching associate professionals $\quad 2.3$

Street vendors and related workers $\quad 2.2$

Garbage collectors and related labourers $\quad 2.2$

Agricultural, fishery and related labourers $\quad 2.1$

Building caretakers, window and related cleaners 2.1

Primary and pre-primary education teaching professionals $\quad 2.1$

Ships deck crews and related workers 2.1

Luxembourg

$\begin{array}{ll}\text { Rubber- and plastic-products machine operators } & 6.7\end{array}$

Mining and construction labourers $\quad 3.8$

Domestic and related helpers, cleaners etc $\quad 2.6$

$\begin{array}{ll}\text { Other office clerks } & 2.2\end{array}$

Netherlands

Wood-products machine operators $\quad 3.2$

Business services agents and trade brokers $\quad 2.4$

Social science and related professionals 2.3

Health associate professionals (except nursing) $\quad 2.3$

Production and operations managers $\quad 2.2$

Nursery and midwifery associate professionals $\quad 2.2$

$\begin{array}{ll}\text { Computing professionals } & 2.2\end{array}$

Police inspectors and detectives $\quad 2.1$

$\begin{array}{lr}\text { Managers of small enterprises } & 2.1 \\ \text { Directors and chief executives } & 2.1\end{array}$ 
Table 4.8 (continued)

Occupational specialization of the EU Member States, 1994

Member State and occupation

specialization-index

Portugal

Primary education teaching associate prof.

5.0

Pelt, leather and shoemaking trades workers

Textile, garment and related trades workers $\quad 4.3$

Market gardeners and crop growers $\quad 3.1$

Wood-products machine operators 3.0

Business services agents and trade brokers $\quad 2.8$

$\begin{array}{ll}\text { Armed forces } & 2.8 \\ & 2.8\end{array}$

Managers of small enterprises $\quad 2.6$

Other personal services workers $\quad 2.5$

Safety and quality inspectors $\quad 2.3$

Potters, glass-makers and related trades workers 2.3

$\begin{array}{ll}\text { Street vendors and related workers } & 2.2\end{array}$

Garbage collectors and related labourers $\quad 2.2$

United Kingdom

Other specialist managers 3.8

Nursing and midwifery professionals $\quad 3.5$

Production and operations managers $\quad 3.4$

Mathematicians, statisticians and related professionals 2.9

Senior officials of special-interest organisations 2.5

Special education teaching professionals $\quad 2.1$

Library, mail and related clerks 2.1

College, university and higher education teaching professionals $\quad 2.1$

Legislators and senior government officials 2.1

Source: EUROSTAT, LFS

* Probably the over-representation of some occupations is partly due to the fact that it is not distinguished in some Member States (see table 4.5). 


\section{National and regional forecasts for the Netherlands}

\subsection{ROA's information system on education and the labour market}

In the Netherlands, the Research Centre for Education and the Labour Market (ROA) has developed the Information System on Education and the Labour Market. This information system is intended to increase the transparency of the labour market. The information system indicates both the current and future labour market positions of various occupational and educational categories. It focuses on mediumterm labour market forecasts, in order to give those who are now facing choices regarding their further studies the best possible information about the labour market situation at the time that they will enter the labour market on the completion of their studies. This means that ROA's labour market forecasts have a primarily informational function, like the EURES system. This chapter will briefly describe ROA's approach in forecasting the occupational and educational structure of the labour market in the Netherlands. ${ }^{25}$

Like the research model proposed in Chapter 2, ROA's approach focuses on the relevant flows in the labour market. Under this approach, medium-term forecasts are made of the flows entering and leaving the labour market. The forecasts refer to a period of about five years. The forecasts are compiled for a total of 93 occupational classes and 79 types of education, over the full width of the labour market (see ROA, 1995a).

As a matter of fact, figure 2.1 gives a schematic overview of the forecasting model used in the information system for education and the labour market. In this model the expected demand for new entrants to the labour market and the future supply are brought together for each occupational class and type of education, to indicate their future labour market prospects and the discrepancies between demand and supply in the labour market. The total demand for newcomers to the labour market (i.e., the job openings) consists of the expansion and replacement demand. The expansion demand reflects the movements in employment levels in a particular class or for a particular type of education. Replacement demand refers to the replacement of workers who retire, leave the workforce under the early retirement scheme or due to work disability, temporarily withdraw from the labour market or switch to another occupation etc. The supply side forecasts refer to the supply of new entrants to the labour market, which is the future flow of school-leavers entering the labour market combined with the number of short-term unemployed at the beginning of the forecasting period.

25. See ROA (1995a) and De Grip et al. (1995) for more details. 
The starting point for calculating the expected expansion demand by occupational class and type of education is the medium-term employment forecasts by economic sector in the Netherlands, made by the Central Planning Bureau (CPB). The CPB uses their ATHENA model to forecast employment by economic sector (see module 1 in figure 2.1). This is a multi-sectoral macromodel of the Dutch economy, which distinguishes 14 economic sectors. These economic sectors are classified according to the standard industry classification of Statistics Netherlands (CBS). ${ }^{26}$

In contrast to the traditional manpower-requirements approach, no fixed relations between occupations and types of education are assumed to determine the forecasts of employment by occupational class and type of education. A somewhat more flexible relationship is assumed, based on explanatory variables for the changes in both the occupational and educational structures of employment. In the 'occupational model', the CPB forecasts by economic sector are first transformed into employment by occupational segment using an explanatory model. These forecasts of expansion demand per occupational segment are then further disaggregated into forecasts per occupational class (see module II in figure 2.1 and section 2.1 for a more detailed description of the methodology). As mentioned before, 93 occupational classes are distinguished at present. These occupational classes are an aggregation of the 320 three-digit occupational groups distinguished by Statistics Netherlands according to their standard occupational classification. ${ }^{27}$

In the educational model the forecasts of the expansion demand per type of education (module IV in figure 2.1) are derived from the forecasts by occupational segment, allowing for the fact that changes on the supply side of the labour market affect relative scarcities and lead to substitution processes. Section 2.1 describes the model used to determine these forecasts by type of education (module IV) in more detail. Altogether 79 types of education, based on the five-digit Standard Education Classification (SOI) of the CBS, are distinguished. ${ }^{28}$

A larger component of the expected demand for newcomers to the labour market is the replacement demand. The expected replacement demand per occupational class is modelled in several steps. In the first step, inflow and outflow percentages are determined by means of the so-called cohort components method. These

26. This classification allows for comparability with the International Standard Industrial Classification (ISIC) and the Nomenclatura statistique des activités économiques dans la communauté européene (NACE) classifications.

27. The standard occupational classification of the CBS is comparable to the ISCO'68 classification.

28. The $\mathrm{SOI}$ is an educational classification designed for the Dutch situation, and related to the ISCED classification. 
percentages are translated into the replacement demand by occupational class in the second step, considering only the net flows. In the third step the recent cohort change rates are used to provide the future replacement demand by occupational classes (module III in figure 2.1). The methodology used for modelling this expected replacement demand is described in more detail in section 2.1 .

Module $\mathrm{V}$ of figure 2.1 refers to the forecast of replacement demand by type of education. As described in section 2.1, replacement demand per type of education differs from replacement demand by occupational class.

By providing forecasts of the expected expansion demand and replacement demand by occupational classes and types of education, respectively, the total demand for newcomers to the labour market can be generated. Modules I, II and III, together, provide information on the job openings per occupational class, while modules I, IV and $\mathrm{V}$ provide this information per educational qualification.

The data required for forecasting the expansion and replacement demand by occupational classes and types of education, as described in section 2.1 , is derived from the Labour Force Survey (EBB) of Statistics Netherlands.

The total supply of newcomers on the labour market is forecast in modules $\mathrm{VI}$ and VII in the lower part of figure 2.1. Module VI generates the future flow of schoolleavers entering the labour market, beginning with the so-called 'Reference projections' (Referentieraming) of the Dutch Ministry of Education, Culture and Sciences. These projections cover the number of school-leavers coming from regular education (i.e. full-time initial education) annually. The projections are at a level of aggregation which is too high for the purposes of the information system, so ROA disaggregates them. In a second step, supplementary data is used to estimate the effects of the flows from non-regular education on the educational composition of the flows entering the labour market. The forecasting model to determine the future flow of school-leavers, as described briefly above, is similar to the model described in more detail in section 2.1. The historical data from which the inflow of school-leavers is derived is taken from various available additional statistics.

In module VII the number of short-term unemployed persons at the beginning of the forecasting period is derived from data from Statistics Netherlands.

Indicators of the future labour market situation for newcomers to the labour market and the future risk of labour supply problems are derived, for each type of education, by confronting the expected flows of demand and supply with each other. These indicators show what discrepancy may be expected between the demand and supply for each type of education. To forecast the future labour market 
prospects by educational qualification, an allowance is made for the substitution effects between the various skill categories which can be expected where ex ante shortages or excess supply are forecast. Module VIII represents these substitution effects (see section 2.1 for a more detailed description).

\section{Regional forecasts of occupational employment}

The forecasting model described above provides forecasts on a national level only. ROA has not made regular regional forecasts for the Netherlands, although a study was carried out in 1992 to investigate the possibilities of providing regional forecasts by education and occupation for the Netherlands (see Berendsen et al., 1992). The method used for these regional forecasts was similar to the approach described in section 2.2. The starting point was the regional employment forecasts of the National Bureau of the Public Employment Services, which are based on a multiregional sector model (see Natzijl and Westra, 1991).

\subsection{National forecasts by economic sector, occupation and educational qualification}

This section presents the relevant national forecasts by economic sector, occupation and educational qualification. These forecasts are the most recent results of ROA's information systern, and are published in The labour market by education and occupation to 2000 and its Statistical Appendix (see ROA, 1995a,b). Before presenting these specific forecasts, some general assumptions and the expected expansion demand by economic sector will be discussed.

According to the CPB's employment forecasts per economic sector, the economic upturn of 1994 was set to continue more strongly in 1995, and to weaken somewhat in 1996. Since the current economic upturn may be only temporary, ROA chose the more conservative scenario from the CPB. This scenario assumes a growth in the relevant world trade flows of $4.5 \%$ per year, and deduces economic growth averaging $2 \%$ per year. For 1999 and 2000, the forecasts are based on the assumption that the employment trends predicted by the CPB for 1997 and 1998 will continue.

\section{Forecasts of sectoral employment}

Table 5.1 shows the expected expansion demand for the Netherlands in the period 1995-2000, broken down by economic sectors. The average annual growth in the number of people working is expected to be more than $0.8 \%$ per year. Employment is expected to increase in most of the economic sectors, with the highest growth expected in the non-commercial șervices sector. Expansion demand for other 
commercial services, the chemical industry and in commerce is expected to be almost as high. The largest relative decrease in employment will be in the agricultural sector.

Table 5.1

Expected expansion demand per economic sector for the Netherlands, 1995-2000 (total numbers and average annual percentage)

\begin{tabular}{lrrl}
\hline Economic sector & number & $\begin{array}{l}\text { average } \\
\text { annual \% }\end{array}$ & $\begin{array}{l}\text { qualitative } \\
\text { characteriz. }\end{array}$ \\
\hline Agriculture and fisheries & $-38,300$ & -2.9 & very low \\
Food and beverage industry & $-4,900$ & -0.6 & low \\
Other industry & $-3,000$ & -0.3 & average \\
Chemicals & 11,400 & 1.8 & high \\
Metal and electrical industries & 9,000 & 0.5 & average \\
Energy & 1,300 & 0.4 & average \\
Construction & 13,000 & 0.6 & average \\
Commerce & 92,200 & 1.8 & high \\
Transport, storage and communication & 12,800 & 0.7 & average \\
Other commercial services & 102,400 & 1.9 & high \\
Financial services & $-5,600$ & -0.6 & low \\
Non-commercial services & 87,700 & 2.0 & high \\
Civil service, police, defense and education & $-35,100$ & -0.9 & low \\
Total & & &
\end{tabular}

Source: ROA

All the modules (figure 2.1) generate information which together comprises the labour market information system results for the Netherlands. Forecasts can be made on the basis of the results from each module, but only the forecasts on job openings by occupational classes and educational qualification and the labour market prospects by type of education are presented here, because this is the final information which is most useful for the intended user group (and for presentational purposes).

Job openings by occupation

Table 5.2 shows the occupational classes with the highest number of job openings in the Netherlands in the period 1995-2000, in both absolute and relative terms. The table shows that the highest number of job openings in absolute terms is expected in the occupational class of managers and supervisors in manufacturing $(126,700$ job openings in the forecasting period), which relates largely to middle-management functions in industry and construction. This high number of job openings arises mainly because of the expected expansion demand for this occupational class. 
In relative terms, the programmers and system analysts are expected to enjoy by far the greatest employment growth (12.6\% per year), and this is mainly due to the creation of new jobs. Three-quarters of the job openings arise from expansion demand. The other occupational classes with large relative numbers of job openings also exhibit a high or very high expansion demand. In the case of nursing staff, student nurses and home nursing personnel, senior finance and sales managers and journalists and announcers, the replacement demand is also high.

Most of the occupational classes are also the classes for which the employers' recruitment requirements, in absolute or relative terms, will be highest. The exception is the class of book-keepers and bank employees, for which employment is falling, so that the large number of expected job openings does not immediately mean that employers have to recruit many newcomers.

Table 5.2

Occupational classes with the largest numbers of expected job openings in the Netherlands, in absolute or relative terms, $1995-2000$ (toțal numbers and average annual percentages)

\begin{tabular}{lll}
\hline Occupational class & \multicolumn{3}{c}{ forecast $1995-2000$} \\
& number $\begin{array}{l}\text { average qualitative } \\
\text { annual \% }\end{array}$ & characteriz. \\
\hline
\end{tabular}

absolute

\begin{tabular}{|c|c|c|c|}
\hline Managers and supervisors in manufacturing & 126,700 & 7.1 & high \\
\hline Programmers and system analysts & 97,500 & 12.6 & very high \\
\hline Sales assistants & 90,300 & 6.4 & high \\
\hline Book-keepers and bank employees & 63,200 & 3.3 & average \\
\hline Student nurses and home nursing personnel & 52,500 & 7.7 & high \\
\hline Purchasing and sales clerks & 49,900 & 2.6 & low \\
\hline Secondary and tertiary education teachers & 48,700 & 5.6 & average \\
\hline Drivers and conductors & 48,200 & 4.8 & average \\
\hline Shopkeepers, retail and wholesale staff & 48,000 & 5.3 & average \\
\hline Nursing staff & 46,200 & 7.6 & high \\
\hline Commercial reps., buyers and branch managers & 44,800 & 6.4 & high \\
\hline Senior finance and sales managers & 44,400 & 8.2 & high \\
\hline \multicolumn{4}{|l|}{ relative } \\
\hline Programmers and system analysts & 97,500 & 12.6 & very high \\
\hline Journalists and announcers & 15,400 & 8.5 & very high \\
\hline Accountants and economists & 27,500 & 8.3 & very high \\
\hline Senior finance and sales managers & 44,400 & 8.2 & high \\
\hline Physiotherapists and occupational therapists & 13,800 & 7.9 & high \\
\hline Student nurses and home nursing personnel & 52,500 & 7.7 & high \\
\hline Nursing staff & 46,200 & 7.6 & high \\
\hline Higher electrical engineers & 5,700 & 7.3 & high \\
\hline Scientific researchers, technicians and statisticians & 22,000 & 7.2 & high \\
\hline Managers and supervisors in manufacturing & 126,700 & 7.1 & high \\
\hline Physicians, medical specialists and pharmacists & 15,300 & 6.9 & high \\
\hline Agricultural and environmental engineers & 1,700 & 6.9 & high \\
\hline
\end{tabular}

Source: ROA 
Table 5.3 shows the occupational classes in the Netherlands which face the lowest number of job openings, in absolute and relative terms, in the forecasting period. With one exception, the occupational classes with the fewest job openings in relative terms all face declining demand, which means that the number of job openings for newcomers is entirely determined by the replacement demand. The exception is the class of technical and medical representatives, where the low number of job openings is mainly the result of the very low replacement demand.

Table 5.3

Occupational classes with the lowest numbers of job openings in the Netherlands, in absolute or relative terms, 1995-2000 (total numbers and average annual percentages)

\begin{tabular}{lll}
\hline Occupational class & \multicolumn{2}{c}{ forecast 1995-2000 } \\
number $\begin{array}{l}\text { average qualitative } \\
\text { annual \% characteriz. }\end{array}$
\end{tabular}

absolute

Fishermen and gamekeepers

Electricity and gas supply workers

$\begin{array}{rll}300 & 2.0 & \text { very low } \\ 500 & 3.2 & \text { low } \\ 600 & 2.1 & \text { very low } \\ 900 & 5.2 & \text { average } \\ 1,200 & 2.0 & \text { very low } \\ 1,700 & 6.9 & \text { high } \\ 1,700 & 3.0 & \text { low } \\ 1,700 & 6.1 & \text { high } \\ 1,800 & 3.0 & \text { low } \\ 1,800 & 5.9 & \text { high } \\ 1,900 & 3.5 & \text { average } \\ 2,000 & 5.7 & \text { average } \\ 2,000 & 4.1 & \text { average } \\ 2,000 & 3.5 & \text { average }\end{array}$

Sailors, deckhands

Datatypists and computer operators

Agricultural and environmental engineers

Ship's officers and marine inspectors

Dentists and dental specialists

Smelter workers and drilling hands

Intermediate electrical engineers

Higher mechanical engineers

Translators and other literary professions

Textile production workers

Wood, paper and cardboard product workers

2,000

3.5

average

relative

Fishermen and gamekeepers

Datatypists and computer operators

$300 \quad 2.0 \quad$ very low

Sailors, deckhands and engine-room workers

1,200

Agricultural workers

$600 \quad 2.1$

Road construction workers and pipelayers

12,300

Military professionals

$7,100 \quad 2.3$

Purchasing and sales clerks

Hairdressers and beauticians

Welders and engineering workers

49,900

4,900

very low

very low

very low

very low

very low

Welders and engineering workers 8,600

Technical and medical representatives $\quad 3,500$

Bakers and bakery personnel $\quad 3,300$

3,300
1,800

low

low

low

low

Smelter workers and drilling hands

$1,700 \quad 3.0$

low

low

Source: ROA

In absolute terms, fishermen and gamekeepers, electricity and gas supply workers, sailors, deckhands and engine-room workers and veterinary surgeons are expected to face the lowest number of job openings, ranging from 300 to 900 persons. 
In relative terms, fishermen and gamekeepers, datatypists and computer operators, sailors, deckhands and engine-room workers, agricultural workers, road construction workers and pipelayers and military professionals offer very low numbers of job openings, ranging from 2.0 to $2.3 \%$ per year. These occupational classes have both a negative expansion demand and a very low replacement demand.

Job openings by educational qualification

Table 5.4 shows the types of education with the highest total number of job openings for newcomers to the Dutch labour market, in both absolute and relative terms. The types of education with the highest expected numbers of job openings in absolute terms are all in educational categories which are very large in terms of present employment levels, but for which the number of job openings in relative terms is in general only average or low. The fact that they are large means that there is a large replacement demand in absolute terms, but they are no longer growing strongly. With 86,100 job openings in the period 1995-2001, Retail education at the intermediate vocational level is the largest. Teacher training at higher vocational level and Primary education, both with almost 70,000 job openings, are also high.

The types of education with the most job openings in relative terms are not so large. The list of these types of education consists entirely of higher education courses. Although many of these types of education also enjoy a relatively high replacement demand, for most of them the majority of the job openings result from very high expansion demand. The exception in this respect is Theology at university level, for which the large number of job openings is mainly due to the very high need for replacement workers. Economics, econometrics and business administration, Electrical engineering and information technology and Management at university level are expected to face the largest job openings in relative terms, ranging from 9.3 to $8.5 \%$ per year.

The types of education with the most job openings in relative terms are also those for which employers' recruitment requirements, in relative terms, will be the greatest. Because none of these types of education face any fall in demand, there is in this case no question of an entire group of workers who are more or less being forced to leave the labour market. 
Table 5.4

Types of education with the largest numbers of job openings in the Netherlands, in absolute or relative terms, 1995-2000 (total numbers and average annual percentages)

\begin{tabular}{lll}
\hline Type of education & \multicolumn{3}{c}{ forecast $1995-2000$} \\
number & $\begin{array}{l}\text { average } \\
\text { annual \% }\end{array}$ & chalitative \\
& chacteriz. \\
\hline
\end{tabular}

absolute

IVE, Retail

$\begin{array}{lll}86,100 & 5.0 & \text { average } \\ 69,400 & 5.1 & \text { average } \\ 68,900 & 2.6 & \text { low } \\ 55,800 & 2.6 & \text { low } \\ 53,700 & 3.3 & \text { average } \\ 50,700 & 5.2 & \text { average } \\ 40,600 & 3.5 & \text { average } \\ 39,100 & 3.6 & \text { average } \\ 32,400 & 5.3 & \text { average } \\ 32,000 & 3.6 & \text { average } \\ 29,100 & 6.7 & \text { high } \\ 27,700 & 6.2 & \text { high }\end{array}$

HVE, Teacher training
Primary education

Lower General Secondary Education

Higher General Secondary Education

IVE, nursing and paramedical services

IVE, Community care

PVE, Community care, hotel and catering

HVE, Social and cultural

IVE, Construction technology

UE, Social sciences

HVE, Nursing and paramedical services

27,700

6.2

high

relative

UE, Economics, econometrics and business admin.

$22,600 \quad 9.3 \quad$ very high

UE Electrical engineering and information tech.

6,600

$\begin{array}{ll}9.3 & \text { very high } \\ 8.7 & \text { very high }\end{array}$

UE, Management

4,700

very high

UE, Information science

2,000

very high

HVE, Commercial information science

8.3

8.2

very high

UE, Theology

2,400

very high

HVE, Accounting

$12,500 \quad 8.1$

UE, Mathematics and natural sciences $\quad 17,600$

PVE, Security

very high

high

high

$3,500 \quad 7.4 \quad$ high

UE, Veterinary and medical sciences and dentistry $\quad 20,700 \quad 7.2$ high

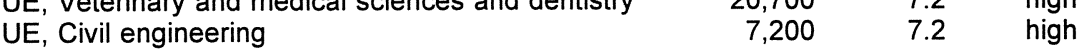

PVE = Preparatory Vocational Education; IVE = Intermediate Vocational Education; HVE = Higher Vocational Education; UE = University Education.

Source: ROA

Table 5.5 lists the types of education with the fewest job openings in the Netherlands, in absolute and relative terms. Most of these types of education face negative expansion demand, which means that the number of job openings is almost entirely dependent on the need to replace departing workers. The exception to this is education in Tourism and recreation at intermediate and higher vocational level. The limited number of job openings for those with these types of education results mainly from the very low replacement demand, combined with the modest size of these educational categories in the labour market.

Printing trades and Utilities installation at preparatory vocational level and Tourism and recreation at intermediate and higher vocational level are expected to face the 
lowest number of job openings, in absolute terms. The number of job openings ranges from 800 to 1,200 .

In relative terms, the number of job openings for preparatory vocational education in Commerce, Food trades and Administration and the intermediate vocational course in Tourism and recreation which has just been mentioned is very low, ranging from 0.9 to $1.8 \%$ per year. The need for replacement workers from all three types of education is very low.

Table 5.5

Types of education with the lowest numbers of job openings in the Netherlands, in absolute or relative terms, 1995-2000 (total numbers and average annual percentages)

\begin{tabular}{lll}
\hline Type of education & \multicolumn{3}{c}{ forecast $1995-2000$} \\
number & average qualitative \\
annual \% characteriz.
\end{tabular}

absolute

PVE, Printing trades

$800 \quad 2.1 \quad$ low

HVE, Tourism and recreation

900

IVE, Tourism and recreation

1,000

PVE, Utilities installation

1,200

1,400

UE, Pharmacy

1,500

1,700

$\begin{array}{lr}\text { HVE, Police, fire and defense forces } & 1,800 \\ \text { HVE, Interpreter and translator } & 2,000\end{array}$

PVE, Food trades

$\begin{array}{ll}\text { HVE, Police, fire and defense forces } & 1,800 \\ \text { HVE, Interpreter and translator } & 2,000\end{array}$

UE, Information science $\quad 2,000$

2,400

2,500

annual \% characteriz.

UE, Theology

$\begin{array}{ll}2.5 & \text { low } \\ 1.3 & \text { very low } \\ 2.4 & \text { low } \\ 5.5 & \text { high } \\ 0.9 & \text { very low } \\ 1.7 & \text { very low } \\ 3.7 & \text { average } \\ 4.6 & \text { average } \\ 8.3 & \text { very high } \\ 8.1 & \text { very high } \\ 5.3 & \text { average }\end{array}$

relative

PVE, Commerce

IVE, Tourism and recreation $\quad 1,000$

1,500 $\quad 0.9 \quad$ very low

PVE, Food trades

1,700

5,800

1.3

very low

PVE, Administration

$800 \quad 1.8$

very low

PVE, Automobile trades $\quad 5,300$

PVE, Printing trades $\quad 800$

PVE, Electrical trades

7,000

17,300

PVE, Construction trades

1,200

PVE, Utilities installation

12,100

IVE, Secretarial

HVE, Tourism and recreation

900

Primary education

68,900

Lover General Secondary Education

55,800

IVE, Agriculture and the natural environment

19,100

very low

low

low

low

low

low

low

low

$\begin{array}{ll}2.6 & \text { low } \\ 2.6 & \text { low }\end{array}$ HVE = Higher Vocational Education; UE = University Education.

Source: ROA 
Labour market prospects by educational qualification

Table 5.6 gives an overview of the types of education with good labour market prospects in the year 2000. IFL stands for Indicator of the Future Labour market situation. The table shows that it is mainly types of education at higher vocational and university level which have good labour market prospects. But even at the preparatory vocational level there are a number of types of education with good prospects: Transport and harbour and Community care, hotel and catering. The good prospects for these types of education are due to relatively low inflows of school-leavers and relatively high replacement demand.

At the intermediate level the labour market prospects are good for: Legal and fiscal, Micro-mechanical technology, Medical laboratory, Police, fire and defense, Transport and harbour, Printing technology, Textile and leather technology and Nursing and paramedical services. '

Most types of education at higher vocational level have good labour market prospects (the prospects are less than good for only five types). The best prospects are for the higher vocational course in Accounting, followed by Commercial information science at higher vocational level. The expansion demand for these types of education is, in relative terms, very high. For Accounting at higher vocational level there is also a very high replacement demand and a low flow of school-leavers entering the labour market.

Other types of education at the higher vocational level with good labour market prospects include Transport and harbour, Construction and civil engineering, Technical laboratory, Medical laboratory, Fine arts, Legal and Fiscal, Teaching training, Electronic and information technology, Nursing and paramedical services, Interpreter and translator, Mechanical engineering, Social and cultural and Police, fire and defense.

With only four exceptions, the labour market prospects for university graduates are good. For most types of education at the university level, the good labour market prospects are due to the relatively high number of job openings. The following types of education at university level are expected to face good prospects: Civil engineering, Theology, Mathematics and natural sciences, Veterinary and medical sciences and dentistry, Electrical engineering and information technology, Economics, econometrics and business administration, Public administration, Information science, Social sciences, Pharmacy, Agriculture and environmental science and Mechanical engineering. 
Table 5.6

Types of education with good labour market prospects in the Netherlands in 2000

Type of education $\mathrm{IFL}^{*}$

Lower General Secondary Education, Preparatory Vocational Education

PVE, Transport and harbour

PVE, Community care, hotel and catering

Higher General Secondary Education, Intermediate Vocational Education

IVE, Legal and fiscal

IVE, Micro-mechanical technology

IVE, Medical laboratory

0.94

IVE, Police, fire and defense

IVE, Transport and harbour

IVE, Printing technology

IVE, Textile and leather technology

1.00

IVE, Nursing and paramedical services

Higher Vocational Education

HVE, Accounting

HVE, Commercial information science

HVE, Transport and harbou

HVE, Construction and civil engineering

0.83

HVE, Technical laboratory

0.85

HVE, Medical laboratory

HVE, Fine Arts

0.93

HVE, Electronic and information technology $\quad 0.94$

HVE, Nursing and paramedical services $\quad 0.94$

HVE, Interpreter and translator

HVE, Mechanical engineering $\quad 0.98$

HVE, Social and cultural $\quad 0.99$

HVE, Police, fire and defense $\quad 0.99$

University Education

UE, Civil engineering $\quad 0.76$

UE, Theology

UE Mathematics and natural sciences $\quad 0.83$

UE, Veterinary and medical sciences and dentistry $\quad 0.83$

UE, Electrical engineering and information technology

UE Economics, econometrics and business administration 0.88

UE, Public administration $\quad 0.88$

UE, Information science $\quad 0.93$

UE, Social sciences $\quad 0.97$

UE, Pharmacy $\quad 0.98$

UE, Agriculture and environmental science 1.00

$\begin{array}{ll}\text { UE, Mechanical engineering } & 1.00\end{array}$

* IFL $=$ Indicator Future Labour market situation

$\mathrm{PVE}=$ Preparatory Vocational Education; IVE = Intermediate Vocational Education;

$\mathrm{HVE}=$ Higher Vocational Education; UE = University Education.

Source: ROA 
Finally, Table 5.7 presents the types of education with bad prospects in the Netherlands in the year 2000. Only a limited number of types of education are expected to offer bad future labour market prospects for newcomers to the labour market, but it is striking that there is at least one such type of education at every educational level.

Table 5.7

Types of education with bad prospects in the Netherlands in 2000

Type of education

$\mathrm{IFL}^{*}$

Lower General Secondary Education, Preparatory Vocational Education

PVE, Food trades

PVE, Commerce

Higher General Secondary Education, Intermediate Vocational Education

IVE, Tourism and recreation $\quad 1.26$

IVE, Automobile technology $\quad 1.22$

$\begin{array}{ll}\text { IVE, Social and cultural } & 1.20\end{array}$

Higher Vocational Education

HVE, Commerce

University Education

UE, Fine Arts

* $\mathrm{IFL}=$ Indicator Future Labour market situation

$\mathrm{PVE}=$ Preparatory Vocational Education; IVE = Intermediate Vocational Education; HVE = Higher Vocational Education; UE = University Education.

Source: ROA

The bad prospects for Food trades at preparatory vocational level are attributable mainly to the very low replacement demand and the negative expansion demand. Moreover, school-leavers from this type of education are being crowded out of their traditional occupational domain by school-leavers from other types of education. For Tourism and recreation at intermediate vocational level, a relatively high flow of school-leavers entering the labour market is coupled with a limited number of job openings for newcomers to the labour market, mainly because of the very low replacement demand. The labour market prospects for school-leavers from Commerce, Intermediate Vocational Education, Automobile technology at higher vocational level and Social and cultural at intermediate vocational level are also bad, because of a combination of high flows entering the labour market and a limited number of job openings for newcomers. For Commerce at preparatory vocational level, the bad labour market prospect result from the very small number of job openings for newcomers to the labour market, which is due largely to the very 
low replacement demand. At university level the labour market prospect are bad for Fine Arts.

\subsection{Regional forecasts by occupation}

As mentioned before, ROA has not provided regional employment forecasts for the Netherlands on a regular basis. However regional forecasts of expansion demand by occupational class for the Netherlands have been compiled especially for this report. The method used for these regional forecasts is similar to the approach described in section 2.2 and a previous regional forecasting study by ROA (see Berendsen et al., 1992). The forecasts of expected expansion demand by occupation and region are based on the existing regional employment forecasts of the National Bureau of Public Employment Services, the CBA (see Natzijl and Westra, 1995). These forecasts employ a multi-regional sector model and build on the national short-term and medium-term employment forecasts by economic sector made by the Central Planning Bureau. ROA also uses these CPB forecasts as a starting point for the national employment forecasts (see section 2.1, 5.1 and 5.2). However ROA's forecasts of national expansion demand are built on the more conservative scenario of the CPB, whereas the CBA built its forecasts on the optimistic $C P B$ scenario. To make the regional employment forecasts by economic sector from the CBA consistent with ROAs national forecasts, we calculated the difference between the CBA's figure for employment growth rate per economic sector for each region ${ }^{29}$ and the national employment growth rate in that particular sector, also provided by the CBA. The differences per economic sector and region are combined with the national employment growth rate used by ROA. This gives the employment growth rate per economic sector ${ }^{30}$ and region. From this point forward the method is identical to that described in section 2.2 (and Berendsen et al.), which results in forecasts of the regional expansion demand by occupational class.

\section{Regional forecasts of sectoral employment}

Table 5.8 presents the expected expansion demand by economic sector and region in the Netherlands for the period 1995-2000. The forecast expansion demand is, on average, highest in the regions of Flevoland, Noord-Brabant and Gelderland and lowest in Noord-Holland and Zuid-Holland. In most of the regions the other

29. The 28 regions distinguished by the CBA have been aggregated to the 12 regions distinguished in the EURES system.

30. The sectoral classification used by the CBA, which differs in some respects from that used by ROA, has been transformed into the ROA classification system. 
commercial services sector is expected to enjoy high relative expansion demand, ranging from $0.6 \%$ in Noord-Holland to $5.3 \%$ per year in Flevoland. In absolute terms, the commerce, other commercial services and non-commercial services sectors are expected to show by far the greatest employment growth in most of the regions. In all regions the expansion demand is expected to decline most sharply, relative to employment levels, in the agriculture and fisheries sector, by amounts ranging from $-3.6 \%$ in Zeeland to $-1.6 \%$ per year in Zuid-Holland. Negative expansion demand is also expected for civil servants, police, defence and eduction in all regions, except Flevoland. This fall in employment levels ranges from $-1.8 \%$ in Groningen to $-0.6 \%$ per year in Noord-Brabant.

In absolute terms the expected expansion demand in the period 1995-2000 is expected to be lowest for civil servants, police, defence and education in most regions, with employment falls ranging from 9,800 persons in Zuid-Holland to 1,400 in Zeeland. However, for Flevoland an increase of employment in this occupational class of 4,200 is forecast. 
Table 5.8

Regional expected expansion demand by economic sector for the Netherlands, 1995-2000 (total number and average annual percentage)

\begin{tabular}{|c|c|c|c|}
\hline Region and economic sector & number & $\begin{array}{r}\text { average } \\
\text { annual \% }\end{array}$ & $\begin{array}{l}\text { qualitative } \\
\text { characteriz. }\end{array}$ \\
\hline \multicolumn{4}{|l|}{ Groningen } \\
\hline Agriculture and fisheries & $-1,400$ & -3.5 & very low \\
\hline Food and beverage industry & -400 & -1.6 & very low \\
\hline Other industry & -300 & -0.6 & low \\
\hline Chemicals & 200 & 0.9 & average \\
\hline Metal and electrical industries & -900 & -1.0 & low \\
\hline Energy & - & 0.1 & average \\
\hline Construction & 1,200 & 1.7 & high \\
\hline Commerce & 400 & 0.4 & average \\
\hline Transport, storage and communication, & - & -0.0 & average \\
\hline Other commercial services & 4,000 & 3.3 & very high \\
\hline Financial services & 200 & 0.9 & average \\
\hline Non-commercial services & 1,800 & 1.1 & average \\
\hline Civil servants, police, defence and education & $-3,500$ & -1.8 & very low \\
\hline \multicolumn{4}{|l|}{ Friesland } \\
\hline Agriculture and fisheries & $-2,600$ & -3.4 & very low \\
\hline Food and beverage industry & -400 & -0.9 & low \\
\hline Other industry & 200 & 0.3 & average \\
\hline Chemicals & 200 & 1.6 & high \\
\hline Metals and electrical industries & 1,000 & 1.4 & high \\
\hline Energy & - & -0.4 & low \\
\hline Construction & 3,600 & 3.1 & very high \\
\hline Commerce & 3,700 & 2.6 & very high \\
\hline Transport, storage and communication & 400 & 0.7 & average \\
\hline Other commercial services & 3,600 & 3.0 & very high \\
\hline Financial services & 300 & 0.6 & average \\
\hline Non-commercial services & 2,000 & 1.2 & average \\
\hline Civil servants, police, defence and education & $-2,500$ & -1.7 & very low \\
\hline \multicolumn{4}{|l|}{ Drenthe } \\
\hline Agriculture and fisheries & $-2,100$ & -3.5 & very low \\
\hline Food and beverage industry & -500 & -2.5 & very low \\
\hline Other industry & 900 & 2.8 & very high \\
\hline Chemicals & - & -0.1 & average \\
\hline Metals and electrical industries & 800 & 0.9 & average \\
\hline Energy & -100 & -0.4 & low \\
\hline Construction & 300 & 0.5 & average \\
\hline Commerce & 2,600 & 2.6 & very high \\
\hline Transport, storage and communication. & 200 & 0.6 & average \\
\hline Other commercial services & 2,300 & 2.4 & very high \\
\hline Financial services & - & -0.1 & average \\
\hline Non-commercial services & 2,200 & 1.7 & high \\
\hline Civil servants, police, defence and education & $-1,600$ & -1.2 & low \\
\hline
\end{tabular}


Table 5.8 (continued)

Regional expected expansion demand by economic sector for the Netherlands, 1995-2000 (total number and average annual percentage)

\begin{tabular}{|c|c|c|c|}
\hline Region and economic sector & number & $\begin{array}{r}\text { average } \\
\text { annual \% }\end{array}$ & $\begin{array}{l}\text { qualitative } \\
\text { characteriz. }\end{array}$ \\
\hline \multicolumn{4}{|l|}{ Overijssel } \\
\hline Agriculture and fisheries & $-3,100$ & -2.9 & very low \\
\hline Food and beverage industry & 200 & 0.3 & average \\
\hline Other industry & $-1,100$ & -0.9 & low \\
\hline Chemicals & 1,700 & 2.6 & very high \\
\hline Metals and electrical industries & 2,500 & 1.3 & high \\
\hline Energy & 100 & 0.5 & average \\
\hline Construction & 3,500 & 1.8 & high \\
\hline Commerce & 5,000 & 2.0 & high \\
\hline Transport, storage and communication & 700 & 0.8 & average \\
\hline Other commercial services & 7,800 & 3.5 & very high \\
\hline Financial services & 500 & 1.1 & average \\
\hline Non-commercial services & 5,700 & 1.9 & high \\
\hline Civil servants, police, defence and education & $-2,600$ & -1.0 & low \\
\hline \multicolumn{4}{|l|}{ Gelderland } \\
\hline Agriculture and fisheries & $-5,100$ & -3.1 & very low \\
\hline Food and beverage industry & -400 & -0.3 & low \\
\hline Other industry & 3,000 & 1.6 & high \\
\hline Chemicals & 1,700 & 2.1 & high \\
\hline Metals and electrical industries & 4,900 & 1.6 & high \\
\hline Energy & 300 & 0.8 & average \\
\hline Construction & 3,000 & 1.0 & average \\
\hline Commerce & 16,100 & 3.2 & very high \\
\hline Transport, storage and communication & 4,600 & 2.4 & very high \\
\hline Other commercial services & 12,100 & 2.4 & very high \\
\hline Financial services & - & -0.0 & average \\
\hline Non-commercial services & 10,600 & 1.6 & high \\
\hline Civil servants, police, defence and education & $-6,700$ & -1.3 & low \\
\hline \multicolumn{4}{|l|}{ Utrecht } \\
\hline Agriculture and fisheries & $-1,600$ & -2.9 & very low \\
\hline Food and beverage industry & -900 & -2.1 & very low \\
\hline Other industry & 100 & 0.1 & average \\
\hline Chemicals & 100 & 0.3 & average \\
\hline Metals and electrical industries & 2,100 & 1.8 & high \\
\hline Energy & 100 & 0.9 & average \\
\hline Construction & 1,600 & 1.2 & average \\
\hline Commerce & 7,000 & 1.9 & high \\
\hline Transport, storage and communication & 3,900 & 3.0 & very high \\
\hline Other commercial services & 9,000 & 2.5 & very high \\
\hline Financial services & 100 & 0.1 & average \\
\hline Non-commercial services & 8,800 & 2.1 & high \\
\hline Civil servants, police, defence and education & $-3,000$ & -0.8 & low \\
\hline
\end{tabular}


Table 5.8 (continued)

Regional expected expansion demand by economic sector for the Netherlands, 1995-2000 (total number and average annual percentage)

\begin{tabular}{|c|c|c|c|}
\hline Region and economic sector & number & $\begin{array}{r}\text { average } \\
\text { annual \% }\end{array}$ & $\begin{array}{l}\text { qualitative } \\
\text { characteriz. }\end{array}$ \\
\hline \multicolumn{4}{|l|}{ Noord-Holland } \\
\hline Agriculture and fisheries & $-3,600$ & -2.7 & very low \\
\hline Food and beverage industry & -900 & -0.9 & low \\
\hline Other industry & -500 & -0.3 & low \\
\hline Chemicals & 1,100 & 1.6 & high \\
\hline Metals and electrical industries & $-2,900$ & -1.1 & low \\
\hline Energy & 100 & 0.2 & average \\
\hline Construction & $-4,000$ & -1.2 & low \\
\hline Commerce & 4,200 & 0.6 & average \\
\hline Transport, storage and communication & 900 & 0.2 & average \\
\hline Other commercial services & 5,000 & 0.6 & average \\
\hline Financial services & $-4,700$ & -1.9 & very low \\
\hline Non-commercial services & 19,900 & 2.1 & high \\
\hline Civil servants, police, defence and education & $-5,500$ & -0.8 & low \\
\hline \multicolumn{4}{|l|}{ Zuid-Holland } \\
\hline Agriculture and fisheries & $-3,700$ & -1.6 & very low \\
\hline Food and beverage industry & -700 & -0.6 & low \\
\hline Other industry & $-1,200$ & -0.7 & low \\
\hline Chemicals & 2,400 & 1.9 & high \\
\hline Metals and electrical industries & $-3,400$ & -0.9 & low \\
\hline Energy & 300 & 0.3 & average \\
\hline Construction & -300 & -0.1 & average \\
\hline Commerce & 11,400 & 1.1 & average \\
\hline Transport, storage and communication & $-4,700$ & -0.9 & low \\
\hline Other commercial services & 8,400 & 0.8 & average \\
\hline Financial services & $-4,100$ & -1.6 & very low \\
\hline Non-commercial services & 21,200 & 2.0 & high \\
\hline Civil servants, police, defence and education & $-9,800$ & -0.9 & low \\
\hline \multicolumn{4}{|l|}{ Zeeland } \\
\hline Agriculture and fisheries & $-1,400$ & -3.6 & very low \\
\hline Food and beverage industry & -100 & -0.7 & low \\
\hline Other industry & 100 & 0.9 & average \\
\hline Chemicals & 600 & 1.8 & high \\
\hline Metals and electrical industries & -100 & -0.1 & average \\
\hline Energy & 100 & 0.4 & average \\
\hline Construction & 200 & 0.4 & average \\
\hline Commerce & 1,600 & 1.5 & high \\
\hline Transport, storage and communication & -100 & -0.3 & average \\
\hline Other commercial services & 1,400 & 1.5 & high \\
\hline Financial services & -100 & -0.9 & low \\
\hline Non-commercial services & 1,600 & 1.5 & high \\
\hline Civil servants, police, defence and education & $-1,400$ & -1.4 & very low \\
\hline
\end{tabular}


Table 5.8 (continued)

Regional expected expansion demand by economic sector for the Netherlands, 1995-2000 (total number and average annual percentage)

\begin{tabular}{|c|c|c|c|}
\hline Region and economic sector & number & $\begin{array}{r}\text { average } \\
\text { annual \% }\end{array}$ & $\begin{array}{l}\text { qualitative } \\
\text { characteriz. }\end{array}$ \\
\hline \multicolumn{4}{|l|}{ Noord-Brabant } \\
\hline Agriculture and fisheries & $-4,300$ & -2.3 & very low \\
\hline Food and beverage industry & 200 & 0.1 & average \\
\hline Other industry & $-1,300$ & -0.6 & low \\
\hline Chemicals & 3,300 & 2.5 & very high \\
\hline Metals and electrical industries & 2,700 & 0.5 & average \\
\hline Energy & 300 & 0.9 & average \\
\hline Construction & 5,500 & 1.4 & high \\
\hline Commerce & 19,300 & 2.7 & very high \\
\hline Transport, storage and communication & 6,500 & 2.6 & very high \\
\hline Other commercial services & 15,900 & 2.8 & very high \\
\hline Financial services & 600 & 0.4 & average \\
\hline Non-commercial services & 14,700 & 2.3 & very high \\
\hline Civil servants, police, defence and education & $-3,700$ & -0.6 & low \\
\hline \multicolumn{4}{|l|}{ Limburg } \\
\hline Agriculture and fisheries & $-2,200$ & -2.3 & very low \\
\hline Food and beverage industries & -700 & -1.4 & very low \\
\hline Other industry & $-2,500$ & -1.8 & very low \\
\hline Chemicals & 800 & 1.0 & average \\
\hline Metals and electrical industries & 3,200 & 1.2 & average \\
\hline Energy & 100 & 0.6 & average \\
\hline Construction & -500 & -0.3 & low \\
\hline Commerce & 6,200 & 2.1 & high \\
\hline Transport, storage and communication & -300 & -0.2 & average \\
\hline Other commercial services & 7,200 & 2.6 & very high \\
\hline Financial services & 100 & 0.1 & average \\
\hline Non-commercial services & 6,600 & 1.8 & high \\
\hline Civil servants, police, defence and education & $-3,000$ & -1.0 & low \\
\hline \multicolumn{4}{|l|}{ Flevoland } \\
\hline Agriculture and fisheries & -900 & -2.8 & very low \\
\hline Food and beverage industry & 500 & 3.3 & very high \\
\hline Other industry & 200 & 0.9 & average \\
\hline Chemicals & & 5.4 & very high \\
\hline Metals and electrical industries & 2,100 & 7.2 & very high \\
\hline Energy & & 4.2 & very high \\
\hline Construction & -300 & -1.0 & low \\
\hline Commerce & 5,200 & 5.1 & very high \\
\hline Transport, storage and communication & 2,400 & 5.5 & very high \\
\hline Other commercial services & 4,000 & 5.3 & very high \\
\hline Financial services & 700 & 3.2 & very high \\
\hline Non-commercial services & 6,900 & 7.2 & very high \\
\hline Civil servants, police, defence and education & 4,200 & 4.8 & very high \\
\hline
\end{tabular}

- = nil

= less than 2,000 employed persons in 1995

Source: ROA 
Regional expansion demand by occupation

Table 5.9 presents the occupational classes which are expected to enjoy the largest relative expansion demand by region in the Netherlands in the period 1995-2000. ${ }^{31}$ The table shows that, in all regions, the relative expected expansion demand is by far the highest for programmers and system analysts. The expected employment growth for this occupational class ranges from $7.6 \%$ in Zuid-Holland to $12.7 \%$ per year in Flevoland. In most regions the next highest expansion demand is forecast for accountants and economists, ranging from $4.0 \%$ in Noord-Holland and ZuidHolland to $5.5 \%$ per year in Utrecht. In Groningen and Friesland senior finance and sales managers are expected to have the next highest expansion demand (2.7 and $4.0 \%$ per year, respectively). In Drenthe and Zeeland the sales assistants are expected to have the next highest expansion demand (3.8 and 2.7\% per year, respectively), whereas in Flevoland student nurses and home nursing personnel are expected to hold the second place ( $7.2 \%$ per year). Other occupations which are expected to enjoy high relative expansion demand in this period include joumalists and announcers (all regions except Groningen, Friesland, Drenthe, Zeeland and Flevoland), managers and supervisors in manufacturing (Groningen, Friesland, Drenthe, Gelderland, Zeeland, Flevoland), physiotherapists and occupational therapists (Utrecht, Noord-Holland, Zuid-Holland, Limburg), scientific researchers, technicians and statisticians (Overijssel, Noord-Brabant, Limburg) and finally commercial representatives, buyers and branch managers (Friesland, Drenthe).

Table 5.10 gives an overview of the occupational classes with the lowest relative expected expansion demand by regions in the Netherlands for the period 1995$2000 .^{32}$ The agricultural workers and civil servants (public administration) are expected to be the major occupational losers. The expected expansion demand for this occupational class ranges from $-2.2 \%$ per year in Flevoland to $-3.8 \%$ per year in Zuid-Holland. Falling employment is also forecast for farmers and for porters, cleaners and domestics, except that the latter group may expect employment growth in Flevoland of $2.2 \%$ per year.

31. Only the occupational classes which have more than 2,000 employed persons at the beginning of the forecasting period are presented.

32. Again, only the occupational classes which have more than 2,000 employed persons at the beginning of the forecasting period are presented. 
Table 5.9

Occupational classes forecast to have the largest relative expansion demand per region in the Netherlands, 1995-2000 (total numbers and average annual percentages)

\begin{tabular}{|c|c|c|c|}
\hline Region and occupational class & number & $\begin{array}{r}\text { average } \\
\text { annual \% }\end{array}$ & $\begin{array}{l}\text { qualitative } \\
\text { characteriz. }\end{array}$ \\
\hline \multicolumn{4}{|l|}{ Groningen } \\
\hline Programmers and system analysts & 2,100 & 8.4 & very high \\
\hline Senior finance and sales managers & 500 & 2.7 & high \\
\hline Managers and supervisors in manufacturing & 1,400 & 2.5 & high \\
\hline Sales assistants & 800 & 2.1 & high \\
\hline Nursing staff & 400 & 1.9 & high \\
\hline \multicolumn{4}{|l|}{ Friesland } \\
\hline Programmers and system analysts & 2,200 & 8.9 & very high \\
\hline Senior finance and sales managers & 700 & 4.0 & very high \\
\hline Sales assistants & 1,800 & 3.8 & very high \\
\hline Managers and supervisors in manufacturing & 2,400 & 3.8 & very high \\
\hline Commercial reps., buyers and branch managers & 600 & 2.5 & high \\
\hline \multicolumn{4}{|l|}{ Drenthe } \\
\hline Programmers and system analysts & 1,700 & 8.4 & very high \\
\hline Sales assistants & 1,300 & 3.8 & very high \\
\hline Senior finance and sales managers & 400 & 3.2 & high \\
\hline Commercial reps., buyers and branch managers & 400 & 2.8 & high \\
\hline Managers and supervisors in manufacturing & 1,400 & 2.6 & high \\
\hline \multicolumn{4}{|l|}{ Overijssel } \\
\hline Programmers and system analysts & 4,100 & 9.0 & very high \\
\hline Accountants and economists & 1,000 & 5.3 & very high \\
\hline Journalists and announcers & 600 & 4.2 & very high \\
\hline Scientific researchers, technicians and statisticians & 800 & 3.9 & very high \\
\hline Senior finance and sales managers & 1,300 & 3.8 & very high \\
\hline \multicolumn{4}{|l|}{ Gelderland } \\
\hline Programmers and system analysts & 8,200 & 8.9 & very high \\
\hline Accountants and economists & 2,000 & 5.2 & very high \\
\hline Journalists and announcers & 1,200 & 4.9 & very high \\
\hline Sales assistants & 7,300 & 4.3 & very high \\
\hline Senior finance and sales managers & 2,600 & 4.0 & very high \\
\hline \multicolumn{4}{|l|}{ Utrecht } \\
\hline Programmers and system analysts & 5,800 & 9.2 & very high \\
\hline Accountants and economists & 1,400 & 5.5 & very high \\
\hline Journalists and announcers & 500 & 4.0 & very high \\
\hline Physiotherapists and occupational therapists & 600 & 3.9 & very high \\
\hline Senior finance and sales managers & 1,500 & 3.8 & very high \\
\hline \multicolumn{4}{|l|}{ Noord-Holland } \\
\hline Programmers and system analysts & 10,900 & 7.7 & very high \\
\hline Accountants and economists & 2,400 & 4.0 & very high \\
\hline Physiotherapists and occupational therapists & 1,200 & 3.9 & very high \\
\hline Journalists and announcers & 1,000 & 3.5 & very high \\
\hline Visual and performing artists & 1,100 & 3.1 & high \\
\hline
\end{tabular}


Table 5.9 (continued)

Occupational classes forecast to have the largest relative expansion demand per region in the Netherlands, 1995-2000 (total numbers and average annual percentages)

\begin{tabular}{|c|c|c|c|}
\hline Region and occupational class & number & $\begin{array}{r}\text { average } \\
\text { annual \% }\end{array}$ & $\begin{array}{l}\text { qualitative } \\
\text { characteriz. }\end{array}$ \\
\hline \multicolumn{4}{|l|}{ Zuid-Holland } \\
\hline Programmers and system analysts & 13,500 & 7.6 & very high \\
\hline Accountants and economists & 2,900 & 4.0 & very high \\
\hline Physiotherapists and occupational therapists & 1,400 & 3.7 & very high \\
\hline Journalists and announcers & 1,200 & 3.3 & very high \\
\hline Visual and performing artists & 1,200 & 3.0 & high \\
\hline \multicolumn{4}{|l|}{ Zeeland } \\
\hline Programmers and system analysts & 1,300 & 7.6 & very high \\
\hline Sales assistants & 900 & 2.7 & high \\
\hline Managers and supervisors in manufacturing & 1,000 & 2.5 & high \\
\hline Senior finance and sales managers & 300 & 2.5 & high \\
\hline Nursing staff & 300 & 2.3 & high \\
\hline \multicolumn{4}{|l|}{ Noord-Brabant } \\
\hline Programmers and system analysts & 10,100 & 8.9 & very high \\
\hline Accountants and economists & 2,500 & 5.2 & very high \\
\hline Journalists and announcers & 1,200 & 4.4 & very high \\
\hline Higher electrical engineers & 600 & 4.1 & very high \\
\hline Scientific researchers, technicians and.statisticians & 1,900 & 4.1 & very high \\
\hline \multicolumn{4}{|l|}{ Limburg } \\
\hline Programmers and system analysts & 4,900 & 8.6 & very high \\
\hline Accountants and economists & 1,200 & 5.0 & very high \\
\hline Physiotherapists and occupational therapists & 500 & 3.6 & very high \\
\hline Scientific researchers, technicians and statisticians & 900 & 3.6 & very high \\
\hline Journalists and announcers & 500 & 3.4 & very high \\
\hline \multicolumn{4}{|l|}{ Flevoland } \\
\hline Programmers and system analysts & 1,900 & 12.7 & very high \\
\hline Student nurses and home nursing personnel & 900 & 7.2 & very high \\
\hline Secondary and tertiary education teachers & 1,200 & 7.0 & very high \\
\hline Managers and supervisors in manufacturing & 2,000 & 6.3 & very high \\
\hline Sales assistants & 1,900 & 6.2 & very high \\
\hline
\end{tabular}

Source: ROA 
Table 5.10

Occupational classes forecast to have the lowest relative expansion demand per region in the Netherlands, 1995-2000 (total numbers and average annual percentages)

\begin{tabular}{|c|c|c|c|}
\hline Region and occupational class & number & $\begin{array}{r}\text { average } \\
\text { annual \% }\end{array}$ & $\begin{array}{l}\text { qualitative } \\
\text { characteriz. }\end{array}$ \\
\hline \multicolumn{4}{|l|}{ Groningen } \\
\hline Agricultural workers & -600 & -3.4 & very low \\
\hline Farmers & -700 & -3.1 & very low \\
\hline Porters, cleaners and domestics & -700 & -2.5 & very low \\
\hline Welders and engineering workers & -200 & -1.9 & low \\
\hline Purchasing and sales clerks & $-1,100$ & -1.8 & low \\
\hline \multicolumn{4}{|l|}{ Friesland } \\
\hline Agricultural workers & $-1,100$ & -3.3 & very low \\
\hline Farmers & $-1,200$ & -3.1 & very low \\
\hline Porters, cleaners and domestics & -600 & -2.3 & very low \\
\hline Food and beverage processors & -200 & -1.5 & low \\
\hline Primary and special education teachers & -200 & -1.4 & low \\
\hline \multicolumn{4}{|l|}{ Drenthe } \\
\hline Agricultural workers & -900 & -3.4 & very low \\
\hline Farmers & $-1,000$ & -3.2 & very low \\
\hline Porters, cleaners and domestics & -400 & -2.2 & low \\
\hline Purchasing and sales clerks & -600 & -1.3 & low \\
\hline Primary and special education teachers & -100 & -1.0 & low \\
\hline \multicolumn{4}{|l|}{ Overijssel } \\
\hline Agricultural workers & $-1,300$ & -2.7 & very low \\
\hline Farmers & $-1,400$ & -2.5 & very low \\
\hline Porters, cleaners and domestics & -800 & -1.8 & low \\
\hline Ceramic and glass industry production workers & -200 & -1.2 & low \\
\hline Carpenters and woodworkers & -500 & -0.8 & low \\
\hline \multicolumn{4}{|l|}{ Gelderland } \\
\hline Civil servants (public administration) & -600 & -3.4 & very low \\
\hline Agricultural workers & $-2,200$ & -2.8 & very low \\
\hline Farmers & $-2,300$ & -2.6 & very low \\
\hline Porters, cleaners and domestics & $-2,100$ & -2.1 & low \\
\hline Hairdressers and beauticians & -400 & -1.7 & low \\
\hline \multicolumn{4}{|l|}{ Utrecht } \\
\hline Civil servants (public administration) & -400 & -3.3 & very low \\
\hline Agricultural workers & -700 & -2.4 & very low \\
\hline Farmers & -700 & -2.1 & low \\
\hline Porters, cleaners and domestics & $-1,300$ & -2.0 & low \\
\hline Hairdressers and beauticians & -300 & -1.6 & low \\
\hline \multicolumn{4}{|l|}{ Noord-Holland } \\
\hline Civil servants (public administration) & -900 & -3.5 & very low \\
\hline Hairdressers and beauticians & $-1,200$ & -3.1 & very low \\
\hline Datatypists and computer operators & -400 & -3.1 & very low \\
\hline Glaziers and concreting hands & -600 & -2.9 & very low \\
\hline Painters & -700 & -2.7 & very low \\
\hline
\end{tabular}


Table 5.10 (continued)

Occupational classes forecast to have the lowest relative expansion demand per region in the Netherlands, 1995-2000 (total numbers and average annual percentages)

\begin{tabular}{|c|c|c|c|}
\hline Region and occupational class & number & $\begin{array}{r}\text { average } \\
\text { annual \% }\end{array}$ & $\begin{array}{l}\text { qualitative } \\
\text { characteriz. }\end{array}$ \\
\hline \multicolumn{4}{|l|}{ Zuid-Holland } \\
\hline Civil servants (public administration) & $-1,300$ & -3.8 & very low \\
\hline Datatypists and computer operators & -500 & -3.5 & very low \\
\hline Hairdressers and beauticians & $-1,300$ & -2.9 & very low \\
\hline Porters, cleaners and domestics & $-4,400$ & -2.5 & very low \\
\hline Intermediate mechanical engineers & -400 & -2.4 & very low \\
\hline \multicolumn{4}{|l|}{ Zeeland } \\
\hline Agricultural workers & -600 & -3.5 & very low \\
\hline Farmers & -700 & -3.3 & very low \\
\hline Porters, cleaners and domestics & -400 & -2.5 & very low \\
\hline Purchasing and sales clerks & -600 & -1.5 & low \\
\hline Primary and special education teacher's & -100 & -1.1 & low \\
\hline \multicolumn{4}{|l|}{ Noord-Brabant } \\
\hline Civil servants (public administration) & -600 & -3.1 & very low \\
\hline Agricultural workers & $-2,000$ & -2.2 & very low \\
\hline Upholsterers, shoemakers and leatherworkers & -400 & -2.2 & very low \\
\hline Clothing production workers and sailmakers & -300 & -2.2 & low \\
\hline Farmers & $-2,100$ & -2.0 & low \\
\hline \multicolumn{4}{|l|}{ Limburg } \\
\hline Agricultural workers & $-1,000$ & -2.2 & very low \\
\hline Porters, cleaners and domestics & $-1,100$ & -2.1 & low \\
\hline Painters & -300 & -2.0 & low \\
\hline Plumbers & -300 & -2.0 & low \\
\hline Farmers & $-1,100$ & -2.0 & low \\
\hline \multicolumn{4}{|l|}{ Flevoland } \\
\hline Agricultural workers & -300 & -2.2 & very low \\
\hline Farmers & -300 & -2.0 & low \\
\hline Porters, cleaners and domestics & 300 & 2.2 & high \\
\hline Purchasing and sales clerks & 900 & 2.7 & high \\
\hline Secretaries and typists & 500 & 3.6 & very high \\
\hline
\end{tabular}

Source: ROA 


\section{National and regional forecasts for the United King- dom}

\subsection{IER's approach}

National forecasts by economic sector, occupation and educational qualification

In the United Kingdom, the Institute for Employment Research (IER) of the University of Warwick is concerned with modelling and forecasting the structure of employment. Since 1978, the IER has generated employment forecasts on an annual basis. This section will briefly describe the approach adopted by the IER in forecasting the structure of employment in the UK (for more details see Wilson, 1994). The prime objective of employment forecasts according to the IER is "to provide a set of points of reference for policy makers and all those interested".

The starting point for analyzing and projecting developments in the labour market is a macroeconomic model developed by Cambridge Econometrics (CE). This model distinguishes 49 economic sectors which are now based on the 1992 standard industrial classification (SIC). The model is still being improved and extended. The IER derives its own forecasts of employment by economic sector using their own version of the Cambridge multisectoral dynamic macroeconomic model (MDM) ${ }^{33}$ of the UK economy. The IER has added several sub-models to disaggregate employment by occupation, employment status ${ }^{34}$ and higher types of education. The institute has also implemented a regional disaggregation.

Figure 6.1 shows the links between the macroeconomic (MDM) model and the submodels, with the exception of the regional/occupation model which will be described later.

33. This model will be referred to as the MDM, ME or CE macroeconomic model.

34. Employment status refers to full-time versus part-time and employee versus self-employed. 
Figure 6.1

IER's macroeconomic model and submodels

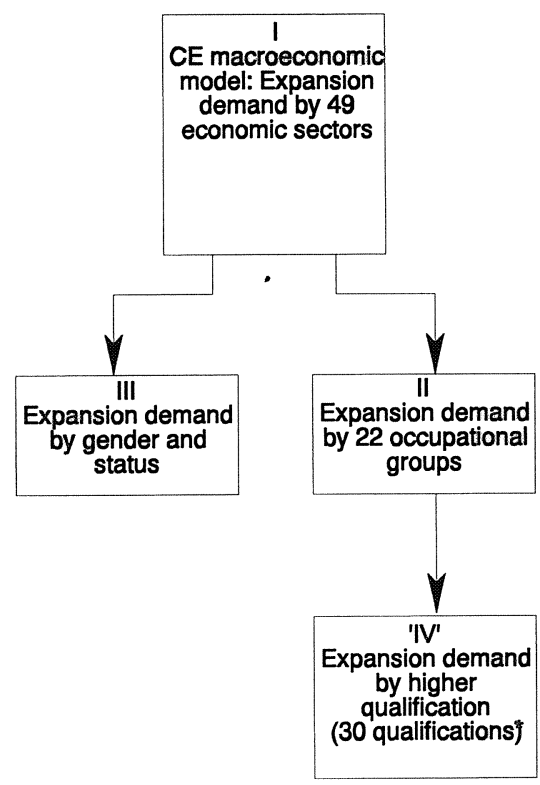

'V \& VI'
Supply of persons
with higher
qualifications
(30 qualifications)

* 10 subject categories are differentiated at each of the 3 levels which are distinguished.

As was noted above, the forecasts of employment by economic sector (module I in figure 6.1) provide the starting point of the manpower forecasting model. These forecasts are the output from a multisectoral macroeconomic model of the national economy. The model consists of a large set of interrelated economic equations which are estimated by means of long time series data sets. The CE model distinguishes 49 economic sectors, which are aggregated into 17 groups $^{35}$ and 6 main sectors for presentation purposes. Although the IER forecasts are, strictly speaking, forecasts of total employment by economic sector, occupation etc., they also pre-

35. In fact these are called industry groups. However in this report they will also be termed economic sectors, to be consistent with the terminology used in the other chapters. 
sent the expansion demand, which is obtained by subtracting employment in the base year of the forecasting period.

Module II disaggregates this sectoral employment to employment by occupation (see figure 6.1). For this model the IER uses data on the occupational structure of employment in the United Kingdom obtained from the Censuses of Population. This occupational structure is forecast basically by extrapolations from recent developments. The resulting occupational proportions are then modified using the available information from the Labour Force Survey (LFS). The resulting occupational structures for employment in each industry are imposed on the industrial employment projections to obtain projections of employment by occupation. In this way each sectoral projection is broken down into projections for 22 occupational categories. These occupations are based on the 1990 Standard Occupational Classification (SOC) of the Office of Population Censuses and Surveys. In presenting the results of the occupational model, these 22 occupations are also aggregated into 9 major occupational groups.

Module IV, which is similar to the one in the research model proposed in chapter 2, transforms the forecasts of expansion demand by occupation into the future expansion demand by educational qualification. To date, the IER has restricted itself to projections of employment for people with higher education (module IV in figure 6.1). The projections of employment by occupation used for this purpose are at a lower level of aggregation, with 79 occupational categories rather than 22 occupations. As these 79 occupations are only used to forecast employment for those with higher qualifications, they are not presented by the IER. Trend extrapolation models are again used, based on data from several Censuses of Population and additional information from the LFS. Altogether 30 types of education are distinguished, ${ }^{36}$ referring to 10 subject categories on each of the 3 levels of qualification which are distinguished: postgraduate, first degree and equivalent, and intermediate-level tertiary education. The 10 fields of study distinguished are given in appendix D. Projections of the employment shares of workers with the various educational qualifications in the employment in each of the 79 occupational categories are combined with the projected employment levels in each category. This yields a projection of future demand for highly qualified persons.

The IER has not, in the past, provided regular forecasts of replacement demand by occupation or by educational qualification (respectively module III and module $\mathrm{V}$ in figure 2.1). However, as part of their labour market forecasts by educational qualification, the IER has recently published forecasts of replacement demand for the 3

36. All qualifications above GCE 'A' level are included. 
levels of education which are distinguished. The inflow of school-leavers by educational qualification (module $\mathrm{VI}$ ) is also not projected in the way described in chapter 2. The IER combines the inflow and outflow methods (modules $V$ and $V I$ in figure 2.1, respectively) with a stock (accqunting) method, to forecast supply, but only for highly qualified persons. ${ }^{37}$

Regional forecasts of employment by occupation

To obtain forecasts of the occupational employment by region, the IER applies the same method as in its forecasts of employment by occupation, which was briefly described above. However, in this case the starting point is a multisectoral regional model (MRM) resembling the multisectoral dynamic model developed by Cambridge Econometrics. In general, the regional forecasts are consistent with the national forecasts: the MRM model is an elaboration of the MDM model. The model produces projections of employment by economic sector at the regional level. Detailed examination of data from the Census of Population and the LFS yields projections of the occupational structure of each industry in each region, using trend extrapolation. Combining these regional/occupational coefficients with the projections of employment by economic sector in each region gives projections of occupational employment (structure) at a regional level. The regions which are distinguished are the 11 Standard Planning Regions of the United Kingdom. These Standard Planning Regions correspond to the regions defined at the NUTS 2 level, except that the South East region is subdivided into Greater London and the rest of South East.

\subsection{National forecasts by econiomic sector, occupation and educational qualification}

The results of the latest projections of employment by occupation for the UK provided by the IER are presented in the Review of the Economy and Employment 1995: Occupational Assessment (Institute for Employment Research, 1995a). The Review consists of three main parts. First the macroeconomic scenario and assumptions underlying the projections and the resulting macroeconomic and labour force prospects for the UK are presented. Then, in accordance with the 'top-down approach', the forecasts of sectoral employment are discussed in detail. Finally the

37. The basis for projecting the supply of persons with higher qualifications is the number of economically active highly qualified persons. To obtain the total number of highly qualified persons for year $t+1$, losses due to deaths and net migration between $t$ and $t+1$ are subtracted and new entrants during this period are added. Combining these with participation rate forecasts yields a projection of the total number of economically active persons with higher qualification. The data for this exercise comes from the Census of Population, the former Department of Education (Age Participation Index) and the Office of Population Censuses and Surveys (official population projection). 
projections of occupational employment are presented. The information contained in the first part of the Review will not be discussed in detail here, but a few aspects will be highlighted.

Expectations are that the growth in GDP will be just under 3 per cent in 1995. For 1996-2001 it is forecast to grow at a rate of $2 \frac{1}{2}$ per cent per year. Government expenditures are also expected to grow over the medium and longer term, except for defence expenditures. Total employment is expected to grow by an average of $0.9 \%$ annually. The labour force is expected to grow steadily, primarily as a result of increasing female participation rates, especially for women aged 25-50, but the cyclical recovery of the economy will also contribute its share. Unemployment is expected to remain above the 2 million mark until 2001. In general, the additional employment is expected to be captured by women and much of it will be part-time employment. Male full-time employment is forecast to decline. It is also expected that there will be 400 thousand additional self-employed persons.

Forecasts of employment by economic sector

Table 6.1 presents the expected expansion demand for the United Kingdom in the period 1994-2001, broken down by economic sectors. As mentioned before, the average annual growth in the number of people working is expected to be $0.9 \%$ per year. Although employment levels are expected to rise, most of the economic sectors are expected to face a decline in employment. Overall there is a shift from agriculture and manufacturing industries to the service sector. This shift is expected to continue in the coming years.

The greatest decline in employment in relative terms is expected for utilities (3\% per year) followed by mining and metals and mineral products (both $1.8 \%$ per year). Banking and business services and hotels and catering are expected to have the highest expansion demand (3.2 and $2.8 \%$ per year, respectively), closely followed by other services and professional services ( 2.7 and $2.6 \%$ per year).

In absolute terms, employment is expected to grow most strongly in banking and business services, health and education services, hotels and catering, and retailing. Job creation in these sectors in the period 1994-2001 will range from 616,000 in banking and business services to 290,000 in retailing. The greatest decline in employment in absolute terms is expected for public administration and defence (176,000 persons). 
Table 6.1

Expected expansion demand by economic sector for the UK, 1994-2001 (total numbers and average annual percentage)

\begin{tabular}{|c|c|c|c|c|}
\hline Economic sector & number & $\begin{array}{c}\text { total } \\
\%\end{array}$ & $\begin{array}{l}\text { average } \\
\text { annual \% }\end{array}$ & $\begin{array}{l}\text { qualitative } \\
\text { characteriz. }\end{array}$ \\
\hline Agriculture & $-19,000$ & -3 & -0.5 & average \\
\hline Mining & $-12,000$ & -13 & -1.8 & low \\
\hline Food, drink and tobacco & $-19,000$ & -4 & -0.5 & average \\
\hline Textiles and clothing & $-15,000$ & -3 & -0.4 & average \\
\hline Chemicals & $-23,000$ & -4 & -0.6 & average \\
\hline Metals and mineral products & $-43,000$ & -13 & -1.8 & low \\
\hline Mechanical engineering & $-68,000$ & -12 & -1.6 & low \\
\hline Electrical engineering & $-14,000$ & -6 & -0.8 & low \\
\hline Motor vehicles & 13,000 & 6 & 0.9 & average \\
\hline Rest engineering & $-75,000$ & -9 & -1.2 & low \\
\hline Other manufacturing & 43,000 & 5 & 0.7 & average \\
\hline Utilities & $-52,000$ & -23 & -3.0 & very low \\
\hline Construction & 18,000 & 1 & 0.2 & average \\
\hline Retailing & 290,000 & 12 & 1.7 & high \\
\hline Hotels and catering & 296,000 & 21 & 2.8 & very high \\
\hline Rest distribution, hotel etc. & 56,000 & 3 & 0.5 & average \\
\hline Transport and communications & $-36,000$ & -3 & -0.4 & average \\
\hline Banking and business services & 616,000 & 25 & 3.2 & very high \\
\hline Professional services & 250,000 & 20 & 2.6 & very high \\
\hline Other services & 257,000 & 21 & 2.7 & very high \\
\hline Manufacturing & $-201,000$ & 4 & 0.6 & average \\
\hline All industries above & $1,464,000$ & 8 & 1.1 & high \\
\hline Public admin. and defence & $-176,000$ & -11 & -1.5 & low \\
\hline Health and education services & 309,000 & 7 & 0.9 & high \\
\hline All industries & $1,597,000$ & 6 & 0.9 & average \\
\hline
\end{tabular}

Source: IER, Review of the Economy and Employment: Occupational Assessment, 1995

\section{Expansion demand by occupation}

Table 6.2 shows the expected expansion demand for the UK in the period 19942001, broken down by occupational groups. In absolute terms, the expected expansion demand will be highest for personal service occupations, corporate managers and administrators, other associate professional occupations and other professional occupations. Employment in these occupations will grow by amounts ranging from 530,000 (personal services occupations) to 247,000 (other professional occupations) persons over the period 1994-2001. The occupations with the lowest absolute expected expansion demand are other elementary occupations, skilled engineering trades and clerical occupations, which will suffer job losses in the forecasting period of $181,000,140,000$ and 71,000 jobs respectively. 
In relative terms, the expected expansion demand is highest for other professional occupations (5.2\% per year), personal service occupations (3.6\% per year) and other associate professional occupations (3.2\% per year). These occupational groups were also among the four occupational groups with the greatest expected growth in absolute terms.

Skilled engineering trades, other occupations in agriculture etc. and other elementary occupations are expected to face the largest declines in employment in relative terms, ranging from -1.8 to $-1.4 \%$ per year.

Table 6.2

Expected expansion demand by occupational group for the UK, 1994-2001 (total number and average annual percentage)

\begin{tabular}{|c|c|c|c|c|}
\hline Occupational group & number & $\begin{array}{c}\text { total } \\
\%\end{array}$ & $\begin{array}{l}\text { average } \\
\text { annual } \%\end{array}$ & $\begin{array}{l}\text { qualitative } \\
\text { characteriz. }\end{array}$ \\
\hline Corporate managers and administrators & 453,000 & 17 & 2.3 & high \\
\hline Managers/proprietors in agr.\& services & 181,000 & 11 & 1.5 & average \\
\hline Science and engineering professionals & 108,000 & 18 & 2.4 & high \\
\hline Health professionals & 28,000 & 16 & 2.2 & high \\
\hline Teaching professionals & 36,000 & 4 & 0.5 & average \\
\hline Other professional occupations & 247,000 & 42 & 5.2 & very high \\
\hline Science and eng. associate occupations & 62,000 & 10 & 1.4 & average \\
\hline Health associate professionals & 14,000 & 2 & 0.3 & average \\
\hline Other associate professional occupations & 259,000 & 25 & 3.2 & high \\
\hline Clerical occupations & $-71,000$ & -3 & -0.4 & low \\
\hline Secretarial occupations & $-19,000$ & -2 & -0.2 & low \\
\hline Skilled construction trades & 63,000 & 11 & 1.4 & average \\
\hline Skilled engineering trades & $-140,000$ & -14 & -1.8 & very low \\
\hline Other skilled trades & $-16,000$ & -1 & -0.1 & low \\
\hline Protective service occupations & 25,000 & 7 & 0.9 & average \\
\hline Personal service occupations & 530,000 & 28 & 3.6 & very high \\
\hline Buyers, brokers and sales representatives & 18,000 & 4 & 0.6 & average \\
\hline Other sales occupations & 101,000 & 7 & 1.0 & average \\
\hline Industrial plant \& machine operators etc. & 1,000 & 0 & 0.0 & low \\
\hline Drivers and mobile machine operators & $-3,000$ & -0 & -0.1 & low \\
\hline Other occupations in agriculture etc. & $-22,000$ & -13 & -1.7 & very low \\
\hline Other elementary occupations & $-181,000$ & -10 & -1.4 & very low \\
\hline All occupations & $1,674,000$ & 7 & 0.9 & average \\
\hline
\end{tabular}

Source: IER, Review of the Economy and Employment: Occupational Assessment, 1995

\section{Expansion demand by educational qualification}

As mentioned before, the IER forecasts by educational qualification refer only to projections of employment for highly qualified persons. The results of the most recent of these forecasts are presented in the Review of the Economy and Employment 1995: Future Employment Prospects for the Highly Qualified (Institute for Employment Research, 1995b). The Review presents projections of the labour 
market for highly qualified persons and is linked to the 1995 Occupational Assessment of the IER, which was discussed above. The data presented in the Occupational Assessment refers to the whole of the UK, whereas the projections of employment of highly qualified persons refer only to Great Britain (i.e. excluding Northern Ireland).

The IER distinguishes between a 'medium-term' and 'high demand' scenario in forecasting employment for highly qualified persons. Only the results of the 'medium-term' scenario will be presented here. ${ }^{38}$ Table 6.3 gives an overview of the expected expansion demand for Great Britain in the period 1991-2001, for highly qualified persons by subject, according to the 'medium-term' scenario. Employment is expected to grow during this period for all highly qualified persons, except those with teacher training at the intermediate level. In all, employment for highly qualified persons is expected to grow by some 1.5 million jobs in this period. The expected relative expansion demand is in general highest for postgraduate studies and lowest for those with intermediate qualifications. With regard to educational qualifications, the expected expansion demand is highest for the social sciences, science, vocational studies and music and other degrees.

The highest expected relative expansion demand for postgraduates is for vocational studies (5.8\% per year), while agriculture is expected to grow most slowly of all the studies at postgraduate level (2.3\% per year). In absolute terms, social science has the highest growth, while agriculture again has the lowest growth $(49,000$ and 1,000 jobs in the forecasting period, respectively).

For first degree graduates the expected relative expansion demand is highest for those with social science and music and other degrees (both $4.7 \%$ per year) and lowest for education degrees i.e. teacher training (1.2\% per year). In absolute terms, the expected expansion demand is highest for social science and lowest for agriculture (352,000 and 10,000 jobs in the period 1991-2001, respectively).

Finally, with respect to intermediate-level qualifications the relative expansion demand is expected to be highest for language ( $4.8 \%$ per year) and lowest for education (-2.4\% per year). In absolute terms, the expected expansion demand is highest for social science, while education again faces the greatest fall (181,000 and $-80,000$ jobs in the forecasting period, respectively).

38. These scenario represents the main features of the trends observed over the 1980 s and how these have influenced the projections for the year 2001. 
Table 6.3

Expected expansion demand for highly qualified persons by subject in Great Britain, mediumterm demand scenario, 1991-2001 (total number and average annual percentage)

\begin{tabular}{lccc}
\hline Subject & number & $\begin{array}{c}\text { average } \\
\text { annual \% }\end{array}$ & $\begin{array}{l}\text { qualitative } \\
\text { characteriz. }\end{array}$
\end{tabular}

Postgraduates

Education
Health
Technology
Agriculture
Science
Social science
Vocational
Language
Music \& other
Other arts
Total

$\begin{array}{rll}14,000 & 4,7 & \text { high } \\ 10,000 & 2,8 & \text { average } \\ 20,000 & 3,7 & \text { average } \\ 1,000 & 2,3 & \text { low } \\ 33,000 & 2,9 & \text { average } \\ 49,000 & 5,0 & \text { high } \\ 9,000 & 5,8 & \text { very high } \\ 8,000 & 3,6 & \text { average } \\ 4,000 & 4,1 & \text { high } \\ 9,000 & 3,5 & \text { average } \\ 158,000 & 3,8 & \text { average }\end{array}$

First degree graduates

Education
Health
Technology
Agriculture
Science
Social science
Vocational
Language
Music \& other
Other arts
Total

$\begin{array}{rll}30,000 & 1,2 & \text { low } \\ 34,000 & 2,0 & \text { low } \\ 73,000 & 1,9 & \text { low } \\ 10,000 & 3,4 & \text { average } \\ 187,000 & 4,2 & \text { high } \\ 352,000 & 4,7 & \text { high } \\ 32,000 & 3,4 & \text { average } \\ 44,000 & 2,5 & \text { average } \\ 57,000 & 4,7 & \text { high } \\ 75,000 & 3,6 & \text { average } \\ 893,000 & 3,4 & \text { average }\end{array}$

Intermediate qualifications

$\begin{array}{lrrl}\text { Education } & -80,000 & -2,4 & \text { very low } \\ \text { Health } & 133,000 & 1,9 & \text { low } \\ \text { Technology } & 87,000 & 1,8 & \text { low } \\ \text { Agriculture } & 5,000 & 1,9 & \text { low } \\ \text { Science } & 46,000 & 4,3 & \text { high } \\ \text { Social science } & 181,000 & 4,1 & \text { high } \\ \text { Vocational } & 18,000 & 2,6 & \text { average } \\ \text { Language } & 3,000 & 4,8 & \text { high } \\ \text { Music \& other } & 25,000 & 4,6 & \text { high } \\ \text { Other arts } & 2,000 & 2,9 & \text { average } \\ \text { Total } & 423,000 & 2,0 & \text { low }\end{array}$

Source: IER, Review of the Economy and Employment: Future employment prospects for the highly qualified, 1995/96

A comparison of supply and demand indicates an overall surplus of highly qualified persons. However the IER expects that substitution between highly qualified persons is likely to lead to a more balanced distribution of any shortfalls or surpluses in practice. The largest imbalances for those with higher degrees are in education and social science. For first degree graduates, science, languages and music and other 
are the disciplines with the greatest surpluses. At the intermediate level, education, technology, social science and vocational studies are areas in which particularly large excess supply may be expected.

Replacement demand by occupation

As mentioned before, the IER does not provide explicit forecasts of replacement demand by occupation or by educational category.

\subsection{Regional employment forecasts by economic sector and occupation}

The results of the most recent projections of regional employment by economic sector and occupation provided by the IER are presented in the Review of the Economy and Employment 1994: Regional Assessment (Institute for Employment Research, 1994). The Review presents employment forecasts by economic sector and occupation for the various regions of the UK. These forecasts correspond to those in the 1994 Occupational Assessment of the IER. The regions which are distinguished by the IER are consistent with the regions used by the EURES Labour Market Information, except that the IER subdivides South East into Greater London and the rest of South East.

Regional expansion demand by economic sector

The regional forecasts by economic sector are presented in a more aggregated form, for 14 economic sectors rather than the 22 sectors distinguished at the national level. Table 6.4 presents the expected expansion demand broken down by economic sectors and regions in the UK for the period 1993-2001.

The expected expansion demand is, on average, highest in the regions of East Anglia, South West and East Midlands. The sector with the highest expected expansion demand in both absolute and relative terms in the period 1993-2001 is business and miscellaneous services (except that in Northern Ireland the absolute expansion demand for public services is expected to be higher). The expected expansion demand for business and miscellaneous services varies from $1.9 \%$ in Northern Ireland to $3.1 \%$ per year in East Midlands. In most regions the next highest expansion demand is expected to be for public services. This ranges from $0.5 \%$ in Greater London to $1.9 \%$ per year in East Midlands.

Expansion demand is expected to decline for most economic sectors during the period 1993-2001, with mineral products experiencing the greatest decline in most regions, ranging from $-2.1 \%$ in Yorkshire \& Humberside and Wales to $-5.0 \%$ in Greater London. The expansion demand for utilities is also expected to decline 
considerably in most regions, ranging from $-2.1 \%$ in Scotland to $-3.7 \%$ per year in West Midlands. Metals and mining etc. are also expected to loose employment.

Table 6.4

Regional expected expansion demand by economic sector for the UK, 1993-2001

\begin{tabular}{|c|c|c|c|}
\hline Economic sector & number & $\begin{array}{l}\text { average } \\
\text { annual \% }\end{array}$ & $\begin{array}{l}\text { qualitative } \\
\text { characteriz. }\end{array}$ \\
\hline $\begin{array}{l}\text { Greater London } \\
\text { Agriculture } \\
\text { Mining etc. } \\
\text { Food, drink and tobacco } \\
\text { Textiles and clothing } \\
\text { Chemicals } \\
\text { Mineral products } \\
\text { Metals } \\
\text { Engineering } \\
\text { Other manufacturing } \\
\text { Utilities } \\
\text { Construction } \\
\text { Distr. hotels, transp. etc. } \\
\text { Public services } \\
\text { Business and misc. services } \\
\text { Total }\end{array}$ & $\begin{array}{r}- \\
- \\
-11,000 \\
-5,000 \\
-9,000 \\
-2,000 \\
-2,000 \\
-23,000 \\
-4,000 \\
-5,000 \\
3,000 \\
14,000 \\
29,000 \\
225,000 \\
207,000\end{array}$ & $\begin{array}{r}-0.4 \\
-0.1 \\
-3.4 \\
-2.2 \\
-2.9 \\
-5.0 \\
-3.5 \\
-2.0 \\
-0.4 \\
-2.5 \\
0.2 \\
0.2 \\
0.5 \\
2.3 \\
0.7\end{array}$ & $\begin{array}{l}\text { average } \\
\text { average } \\
\text { very low } \\
\text { very low } \\
\text { very low } \\
\text { very low } \\
\text { very low } \\
\text { very low } \\
\text { average } \\
\text { very low } \\
\text { average } \\
\text { average } \\
\text { average } \\
\text { very high } \\
\text { average }\end{array}$ \\
\hline $\begin{array}{l}\text { Rest South East } \\
\text { Agriculture } \\
\text { Mining etc. } \\
\text { Food, drink and tobacco } \\
\text { Textiles and clothing } \\
\text { Chemicals } \\
\text { Mineral products } \\
\text { Metals } \\
\text { Engineering } \\
\text { Other manufacturing } \\
\text { Utilities } \\
\text { Construction } \\
\text { Distr. hotels, transp. etc. } \\
\text { Public services } \\
\text { Business and misc. services } \\
\text { Total }\end{array}$ & $\begin{array}{r}-6,000 \\
-1,000 \\
-8,000 \\
-6,000 \\
-9,000 \\
-6,000 \\
-3,000 \\
-45,000 \\
-3,000 \\
-10,000 \\
31,000 \\
74,000 \\
133,000 \\
245,000 \\
386,000\end{array}$ & $\begin{array}{l}-0.8 \\
-1.3 \\
-1.8 \\
-2.8 \\
-1.1 \\
-3.6 \\
-2.1 \\
-1.4 \\
-0.2 \\
-2.5 \\
1.3 \\
0.7 \\
1.5 \\
2.9 \\
1.0\end{array}$ & $\begin{array}{l}\text { low } \\
\text { low } \\
\text { very low } \\
\text { very low } \\
\text { low } \\
\text { very low } \\
\text { very low } \\
\text { low } \\
\text { average } \\
\text { very low } \\
\text { high } \\
\text { average } \\
\text { high } \\
\text { very high } \\
\text { average }\end{array}$ \\
\hline $\begin{array}{l}\text { East Anglia } \\
\text { Agriculture } \\
\text { Mining etc. } \\
\text { Food, drink and tobacco } \\
\text { Textiles and clothing } \\
\text { Chemicals } \\
\text { Mineral products } \\
\text { Metals } \\
\text { Engineering } \\
\text { Other manufacturing } \\
\text { Utilities } \\
\text { Construction } \\
\text { Distr. hotels, transp. etc. } \\
\text { Public services } \\
\text { Business and misc. services } \\
\text { Total }\end{array}$ & $\begin{array}{r}-3,000 \\
0,000 \\
-3,000 \\
-1,000 \\
-3,000 \\
-1,000 \\
0,000 \\
0,000 \\
2,000 \\
-2,000 \\
6,000 \\
25,000 \\
30,000 \\
36,000 \\
87,000\end{array}$ & $\begin{array}{r}-0.9 \\
-0.3 \\
-1.1 \\
-1.9 \\
-1.5 \\
-3.1 \\
-1.3 \\
0.0 \\
0.7 \\
-2.5 \\
1.2 \\
1.2 \\
1.7 \\
2.6 \\
1.2\end{array}$ & $\begin{array}{l}\text { low } \\
\text { average } \\
\text { low } \\
\text { very low } \\
\text { low } \\
\text { very low } \\
\text { low } \\
\text { average } \\
\text { average } \\
\text { very low } \\
\text { high } \\
\text { high } \\
\text { high } \\
\text { very high } \\
\text { average }\end{array}$ \\
\hline
\end{tabular}


Table 6.4 (continued)

Regional expected expansion demand by economic sector for the UK, 1993-2001

\begin{tabular}{|c|c|c|c|}
\hline Economic sector & number & $\begin{array}{l}\text { average } \\
\text { annual \% }\end{array}$ & $\begin{array}{l}\text { qualitative } \\
\text { characteriz. }\end{array}$ \\
\hline $\begin{array}{l}\text { South West } \\
\text { Agriculture } \\
\text { Mining etc. } \\
\text { Food, drink and tobacco } \\
\text { Textiles and clothing } \\
\text { Chemicals } \\
\text { Mineral products } \\
\text { Metals } \\
\text { Engineering } \\
\text { Other manufacturing } \\
\text { Utilities } \\
\text { Construction } \\
\text { Distr. hotels, transp. etc. } \\
\text { Public services } \\
\text { Business and misc. services } \\
\text { Total }\end{array}$ & $\begin{array}{r}2,000 \\
-1,000 \\
-5,000 \\
-2,000 \\
-5,000 \\
-2,000 \\
-1,000 \\
-12,000 \\
-1,000 \\
-5,000 \\
17,000 \\
55,000 \\
58,000 \\
100,000 \\
197,000\end{array}$ & $\begin{array}{r}0.3 \\
-1.5 \\
-1.5 \\
-1.1 \\
-1.9 \\
-2.7 \\
-1.2 \\
-1.0 \\
-0.3 \\
-2.6 \\
1.7 \\
1.2 \\
1.5 \\
3.0 \\
1.2\end{array}$ & $\begin{array}{l}\text { average } \\
\text { low } \\
\text { low } \\
\text { low } \\
\text { very low } \\
\text { very low } \\
\text { low } \\
\text { low } \\
\text { average } \\
\text { very low } \\
\text { high } \\
\text { high } \\
\text { high } \\
\text { very high } \\
\text { average }\end{array}$ \\
\hline $\begin{array}{l}\text { West Midlands } \\
\text { Agriculture } \\
\text { Mining etc. } \\
\text { Food, drink and tobacco } \\
\text { Textiles and clothing } \\
\text { Chemicals } \\
\text { Mineral products } \\
\text { Metals } \\
\text { Engineering } \\
\text { Other manufacturing } \\
\text { Utilities } \\
\text { Construction } \\
\text { Distr. hotels, transp. etc. } \\
\text { Public services } \\
\text { Business and misc. services } \\
\text { Total }\end{array}$ & $\begin{array}{r}-2,000 \\
-3,000 \\
-7,000 \\
-4,000 \\
-6,000 \\
-11,000 \\
-9,000 \\
-16,000 \\
-2,000 \\
-6,000 \\
9,000 \\
52,000 \\
42,000 \\
84,000 \\
122,000\end{array}$ & $\begin{array}{l}-0.4 \\
-4.1 \\
-1.9 \\
-1.5 \\
-1.5 \\
-3.2 \\
-2.7 \\
-0.6 \\
-0.4 \\
-3.7 \\
0.9 \\
1.1 \\
1.0 \\
2.7 \\
0.7\end{array}$ & $\begin{array}{l}\text { average } \\
\text { very low } \\
\text { very low } \\
\text { low } \\
\text { low } \\
\text { very low } \\
\text { very low } \\
\text { average } \\
\text { average } \\
\text { very low } \\
\text { high } \\
\text { high } \\
\text { high } \\
\text { very high } \\
\text { average }\end{array}$ \\
\hline $\begin{array}{l}\text { East Midlands } \\
\text { Agriculture } \\
\text { Mining etc. } \\
\text { Food, drink and tobacco } \\
\text { Textiles and clothing } \\
\text { Chemicals } \\
\text { Mineral products } \\
\text { Metals } \\
\text { Engineering } \\
\text { Other manufacturing } \\
\text { Utilities } \\
\text { Construction } \\
\text { Distr. hotels, transp. etc. } \\
\text { Public services } \\
\text { Business and misc. services } \\
\text { Total }\end{array}$ & $\begin{array}{r}-4,000 \\
-11,000 \\
-1,000 \\
-10,000 \\
-3,000 \\
-7,000 \\
-3,000 \\
7,000 \\
8,000 \\
-4,000 \\
9,000 \\
40,000 \\
63,000 \\
70,000 \\
155,000\end{array}$ & $\begin{array}{r}-1.1 \\
-6.0 \\
-0.2 \\
-1.2 \\
-0.9 \\
-4.1 \\
-2.9 \\
0.6 \\
1.5 \\
-3.1 \\
1.2 \\
1.1 \\
1.9 \\
3.1 \\
1.1\end{array}$ & $\begin{array}{l}\text { low } \\
\text { very low } \\
\text { average } \\
\text { low } \\
\text { low } \\
\text { very low } \\
\text { very low } \\
\text { average } \\
\text { high } \\
\text { very low } \\
\text { high } \\
\text { high } \\
\text { high } \\
\text { very high } \\
\text { average }\end{array}$ \\
\hline
\end{tabular}


Table 6.4 (continued)

Regional expected expansion demand by economic sector for the UK, 1993-2001

\begin{tabular}{|c|c|c|c|}
\hline Economic sector & number & $\begin{array}{l}\text { average } \\
\text { annual \% }\end{array}$ & $\begin{array}{l}\text { qualitative } \\
\text { characteriz. }\end{array}$ \\
\hline $\begin{array}{l}\text { Yorkshire \& Humberside } \\
\text { Agriculture } \\
\text { Mining etc. } \\
\text { Food, drink and tobacco } \\
\text { Textiles and clothing } \\
\text { Chemicals } \\
\text { Mineral products } \\
\text { Metals } \\
\text { Engineering } \\
\text { Other manufacturing } \\
\text { Utilities } \\
\text { Construction } \\
\text { Distr. hotels, transp. etc. } \\
\text { Public services } \\
\text { Business and misc. services } \\
\text { Total }\end{array}$ & $\begin{array}{r}-1,000 \\
-7,000 \\
-8,000 \\
-9,000 \\
-3,000 \\
-4,000 \\
-8,000 \\
-11,000 \\
4,000 \\
-5,000 \\
9,000 \\
26,000 \\
59,000 \\
78,000 \\
120,000\end{array}$ & $\begin{array}{r}-0.3 \\
-4.2 \\
-1.3 \\
-1.8 \\
-0.7 \\
-2.1 \\
-2.7 \\
-0.9 \\
0.7 \\
-3.3 \\
0.9 \\
0.6 \\
1.5 \\
2.7 \\
0.7\end{array}$ & $\begin{array}{l}\text { average } \\
\text { very low } \\
\text { low } \\
\text { very low } \\
\text { low } \\
\text { very low } \\
\text { very low } \\
\text { low } \\
\text { average } \\
\text { very low } \\
\text { high } \\
\text { average } \\
\text { high } \\
\text { very high } \\
\text { average }\end{array}$ \\
\hline $\begin{array}{l}\text { North West } \\
\text { Agriculture } \\
\text { Mining etc. } \\
\text { Food, drink and tobacco } \\
\text { Textiles and clothing } \\
\text { Chemicals } \\
\text { Mineral products } \\
\text { Metals } \\
\text { Engineering } \\
\text { Other manufacturing } \\
\text { Utilities } \\
\text { Construction } \\
\text { Distr. hotels, transp. etc. } \\
\text { Public services } \\
\text { Business and misc. services } \\
\text { Total }\end{array}$ & $\begin{array}{r}-2,000 \\
-1,000 \\
-4,000 \\
-12,000 \\
-8,000 \\
-5,000 \\
-3,000 \\
-20,000 \\
-4,000 \\
-7,000 \\
2,000 \\
23,000 \\
63,000 \\
95,000 \\
117,000\end{array}$ & $\begin{array}{r}-0.7 \\
-3.4 \\
-0.8 \\
-1.9 \\
-1.1 \\
-3.2 \\
-2.4 \\
-1.2 \\
-0.6 \\
-3.0 \\
0.2 \\
0.4 \\
1.2 \\
2.4 \\
0.6\end{array}$ & $\begin{array}{l}\text { low } \\
\text { very low } \\
\text { low } \\
\text { very low } \\
\text { low } \\
\text { very low } \\
\text { very low } \\
\text { low } \\
\text { average } \\
\text { very low } \\
\text { average } \\
\text { average } \\
\text { high } \\
\text { very high } \\
\text { average }\end{array}$ \\
\hline $\begin{array}{l}\text { North } \\
\text { Agriculture } \\
\text { Mining etc. } \\
\text { Food, drink and tobacco } \\
\text { Textiles and clothing } \\
\text { Chemicals } \\
\text { Mineral products } \\
\text { Metals } \\
\text { Engineering } \\
\text { Other manufacturing } \\
\text { Utilities } \\
\text { Construction } \\
\text { Distr. hotels, transp. etc. } \\
\text { Public services } \\
\text { Business and misc. services } \\
\text { Total }\end{array}$ & $\begin{array}{r}-1,000 \\
-4,000 \\
0,000 \\
-2,000 \\
-2,000 \\
-1,000 \\
-3,000 \\
-2,000 \\
0,000 \\
-4,000 \\
6,000 \\
11,000 \\
23,000 \\
34,000 \\
56,000\end{array}$ & $\begin{array}{r}-0.5 \\
-4.2 \\
0.0 \\
-0.8 \\
-0.5 \\
-2.3 \\
-2.9 \\
-0.2 \\
0.1 \\
-2.7 \\
1.0 \\
0.5 \\
0.9 \\
2.3 \\
0.6\end{array}$ & $\begin{array}{l}\text { average } \\
\text { very low } \\
\text { average } \\
\text { low } \\
\text { average } \\
\text { very low } \\
\text { very low } \\
\text { average } \\
\text { average } \\
\text { very low } \\
\text { high } \\
\text { average } \\
\text { high } \\
\text { very high } \\
\text { average }\end{array}$ \\
\hline
\end{tabular}


Table 6.4 (continued)

Regional expected expansion demand by economic sector for the UK, 1993-2001

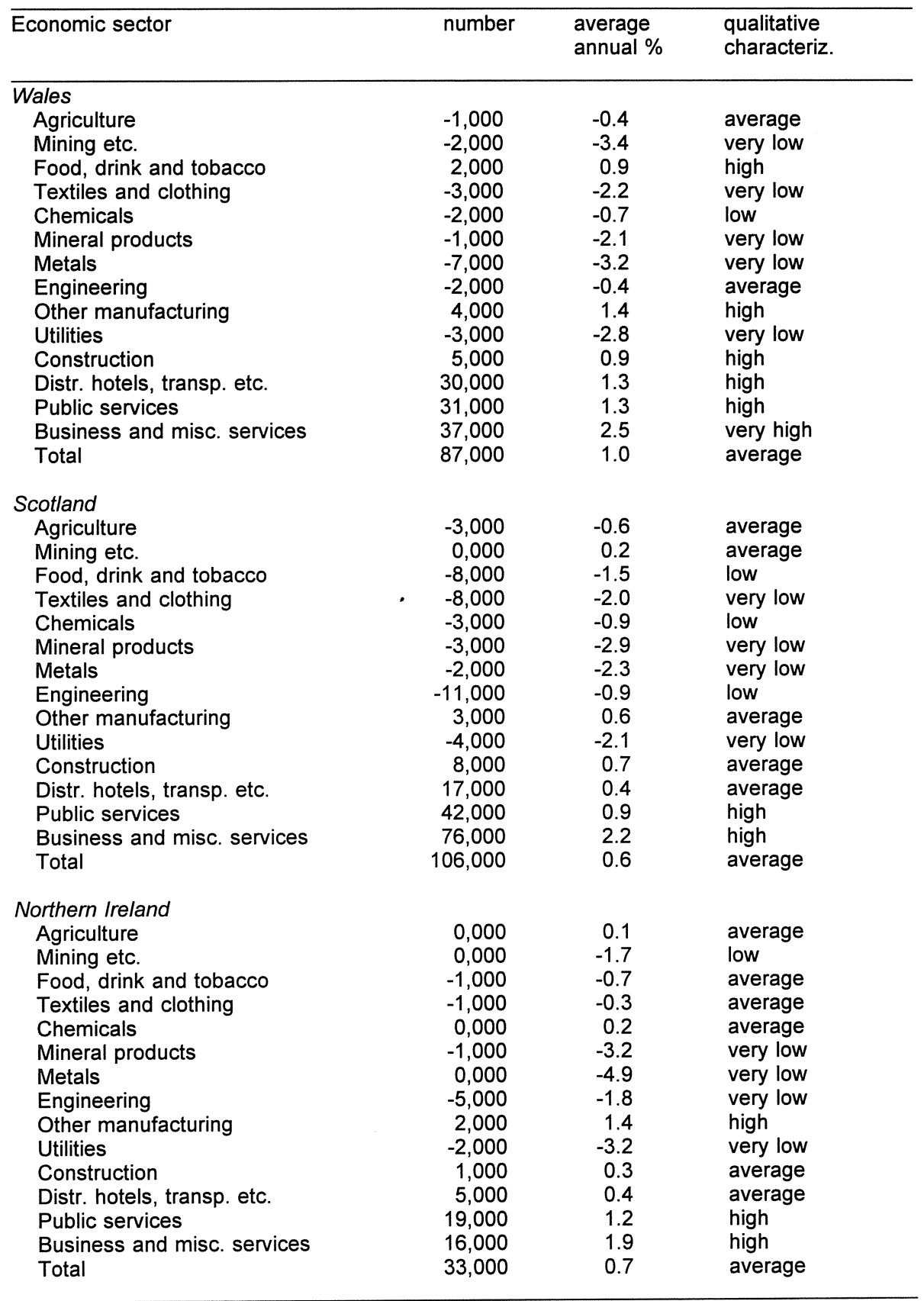

Source: IER, Review of the Economy and Employment: Regional Assessment, 1994 
The regional occupational forecasts, like the sectoral forecasts, are presented at a higher level of aggregation than was used at the national level. Instead of the 22 occupational groups presented at national level, 9 major occupational groups are distinguished.

Table 6.5 gives an overview of the expected expansion demand broken down by occupational groups and regions in the UK for the period 1993-2001. The table shows that the expected expansion demand is highest in the regions of East Anglia, South West and East Midlands. In several regions expansion demand is highest for the professional occupations. The expected employment growth for this occupational group ranges from $1.8 \%$ in the North region to $3.4 \%$ in Greater London. The expected expansion demand is also large for managers and administrators, ranging from $1.6 \%$ in Northern Ireland and the West Midlands to $2.9 \%$ in Greater London. The largest occupational winners are however the personal and protective services occupations. For this occupational group the expected expansion demand is lowest in Greater London and highest in the East Midlands.

The plant and machine operatives are one of the major occupational losers. However the expansion demand for this occupational group ranges from a expected annual decrease of employment in Greater London of $2.6 \%$ to an employment growth of $1.1 \%$ in the South West and Wales. 
Table 6.5

Regional expected expansion demand by major occupational groups for the UK, 1993-2001

\begin{tabular}{|c|c|c|c|}
\hline Major occupational groups & number & $\begin{array}{l}\text { average } \\
\text { annual \% }\end{array}$ & $\begin{array}{l}\text { qualitative } \\
\text { characteriz. }\end{array}$ \\
\hline \multicolumn{4}{|l|}{ Greater London } \\
\hline Managers and administrators & 166,000 & 2.9 & high \\
\hline Professional occupations & 114,000 & 3.4 & very high \\
\hline Associate prof. and technical occ. & 102,000 & 2.7 & high \\
\hline Clerical and secretarial occupations & $-95,000$ & -1.7 & very low \\
\hline Craft and related occupations & $-19,000$ & -0.6 & low \\
\hline Personal and protective services occ. & 49,000 & 1.9 & average \\
\hline Sales occupations & $-5,000$ & -0.3 & low \\
\hline Plant and machine operatives & $-51,000$ & -2.6 & very low \\
\hline Other occupations & $-56,000$ & -2.7 & very low \\
\hline Total & 207,000 & 0.7 & average \\
\hline \multicolumn{4}{|l|}{ Rest South East } \\
\hline Managers and administrators & 186,000 & 2.5 & high \\
\hline Professional occupations & 114,000 & 2.9 & high \\
\hline Associate prof. and technical occ. & 71,000 & 1.9 & average \\
\hline Clerical and secretarial occupations & $-18,000$ & -0.3 & low \\
\hline Craft and related occupations & $-6,000$ & -0.1 & low \\
\hline Personal and protective services occ. & 122,000 & 3.4 & very high \\
\hline Sales occupations & 0,000 & 0.0 & low \\
\hline Plant and machine operatives & $-46,000$ & -1.5 & very low \\
\hline Other occupations & $-38,000$ & -1.4 & very low \\
\hline Total & 386,000 & 1.0 & average \\
\hline \multicolumn{4}{|l|}{ East Anglia } \\
\hline Managers and administrators & 29,000 & 2.2 & high \\
\hline Professional occupations & 19,000 & 2.7 & high \\
\hline Associate prof. and technical occ. & 14,000 & 2.1 & high \\
\hline Clerical and secretarial occupations & $-2,000$ & -0.2 & low \\
\hline Craft and related occupations & 0,000 & 0.0 & low \\
\hline Personal and protective services occ. & 20,000 & 3.0 & high \\
\hline Sales occupations & 7,000 & 1.3 & average \\
\hline Plant and machine operatives & 2,000 & 0.3 & average \\
\hline Other occupations & $-3,000$ & -0.4 & low \\
\hline Total & 87,000 & 1.2 & average \\
\hline \multicolumn{4}{|l|}{ South West } \\
\hline Managers and administrators & 65,000 & 2.2 & high \\
\hline Professional occupations & 32,000 & 2.2 & high \\
\hline Associate prof. and technical occ. & 27,000 & 1.8 & average \\
\hline Clerical and secretarial occupations & 1,000 & 0.04 & low \\
\hline Craft and related occupations & 2,000 & 0.1 & average \\
\hline Personal and protective services occ. & 55,000 & 3.3 & very high \\
\hline Sales occupations & 14,000 & 1.1 & average \\
\hline Plant and machine operatives & 17,000 & 1.1 & average \\
\hline Other occupations & $-16,000$ & -1.2 & low \\
\hline Total & 197,000 & 1.2 & average \\
\hline
\end{tabular}


Table 6.5 (continued)

Regional expected expansion demand by major occupational groups for the UK, 1993-2001

\begin{tabular}{|c|c|c|c|}
\hline Major occupational groups & number & $\begin{array}{l}\text { average } \\
\text { annual \% }\end{array}$ & $\begin{array}{l}\text { qualitative } \\
\text { characteriz. }\end{array}$ \\
\hline \multicolumn{4}{|l|}{ West Midlands } \\
\hline Managers and administrators & 45,000 & 1.6 & average \\
\hline Professional occupations & 39,000 & 2.5 & high \\
\hline Associate prof. and technical occ. & 27,000 & 1.9 & average \\
\hline Clerical and secretarial occupations & 5,000 & 0.2 & average \\
\hline Craft and related occupations & $-11,000$ & -0.4 & low \\
\hline Personal and protective services occ. & 54,000 & 3.2 & high \\
\hline Sales occupations & 11,000 & 0.9 & average \\
\hline Plant and machine operatives & $-11,000$ & -0.5 & low \\
\hline Other occupations & $-36,000$ & -2.4 & very low \\
\hline Total & 122,000 & 0.7 & average \\
\hline \multicolumn{4}{|l|}{ East Midlands } \\
\hline Managers and administrators & 56,000 & 2.4 & high \\
\hline Professional occupations & 42,000 & 3.3 & high \\
\hline Associate prof. and technical occ. & 22,000 & 2.0 & high \\
\hline Clerical and secretarial occupations & 3,000 & 0.2 & average \\
\hline Craft and related occupations & $-21,000$ & -0.9 & low \\
\hline Personal and protective services occ. & 48,000 & 3.6 & very high \\
\hline Sales occupations & 8,000 & 0.8 & average \\
\hline Plant and machine operatives & 5,000 & 0.3 & average \\
\hline Other occupations & $-7,000$ & -0.6 & low \\
\hline Total & 155,000 & 1.1 & average \\
\hline \multicolumn{4}{|l|}{ Yorkshire \& Humberside } \\
\hline Managers and administrators & 50,000 & 1.9 & average \\
\hline Professional occupations & 34,000 & 2.4 & high \\
\hline Associate prof. and technical occ. & 29,000 & 2.0 & high \\
\hline Clerical and secretarial occupations & 7,000 & 0.3 & average \\
\hline Craft and related occupations & $-14,000$ & -0.6 & low \\
\hline Personal and protective services occ. & 52,000 & 3.0 & high \\
\hline Sales occupations & 2,000 & 0.2 & average \\
\hline Plant and machine operatives & $-11,000$ & -0.5 & low \\
\hline Other occupations & $-27,000$ & -1.7 & very low \\
\hline Total & 120,000 & 0.7 & average \\
\hline \multicolumn{4}{|l|}{ North West } \\
\hline Managers and administrators & 55,000 & 1.7 & average \\
\hline Professional occupations & 43,000 & 2.2 & high \\
\hline Associate prof. and technical occ. & 40,000 & 2.0 & high \\
\hline Clerical and secretarial occupations & $-3,000$ & -0.1 & low \\
\hline Craft and related occupations & $-20,000$ & -0.7 & low \\
\hline Personal and protective services occ. & 65,000 & 2.9 & high \\
\hline Sales occupations & 17,000 & 1.0 & average \\
\hline Plant and machine operatives & $-28,000$ & -1.2 & low \\
\hline Other occupations & $-51,000$ & -2.8 & very low \\
\hline Total & 117,000 & 0.6 & average \\
\hline
\end{tabular}


Table 6.5 (continued)

Regional expected expansion demand by major occupational groups for the UK, 1993-2001

\begin{tabular}{|c|c|c|c|}
\hline Major occupational groups & number & $\begin{array}{l}\text { average } \\
\text { annual \% }\end{array}$ & $\begin{array}{l}\text { qualitative } \\
\text { characteriz. }\end{array}$ \\
\hline \multicolumn{4}{|l|}{ North } \\
\hline Managers and administrators & 22,000 & 1.7 & average \\
\hline Professional occupations & 14,000 & 1.8 & average \\
\hline Associate prof. and technical occ. & 9,000 & 1.1 & average \\
\hline Clerical and secretarial occupations & $-8,000$ & -0.6 & low \\
\hline Craft and related occupations & $-9,000$ & -0.6 & low \\
\hline Personal and protective services occ. & 27,000 & 2.6 & high \\
\hline Sales occupations & 9,000 & 1.1 & average \\
\hline Plant and machine operatives & 4,000 & 0.4 & average \\
\hline Other occupations & $-12,000$ & -1.2 & low \\
\hline Total & 56,000 & 0.6 & average \\
\hline \multicolumn{4}{|l|}{ Wales } \\
\hline Managers and administrators & 25,000 & 1.7 & average \\
\hline Professional occupations & 17,000 & 2.1 & high \\
\hline Associate prof. and technical occ. & 14,000 & 1.8 & average \\
\hline Clerical and secretarial occupations & $-3,000$ & -0.2 & low \\
\hline Craft and related occupations & $-5,000$ & -0.4 & low \\
\hline Personal and protective services occ. & 31,000 & 3.1 & high \\
\hline Sales occupations & 3,000 & 0.5 & average \\
\hline Plant and machine operatives & 13,000 & 1.1 & average \\
\hline Other occupations & $-10,000$ & -1.1 & low \\
\hline Total & 87,000 & 1.0 & average \\
\hline \multicolumn{4}{|l|}{ Scotland } \\
\hline Managers and administrators & 52,000 & 2.0 & high \\
\hline Professional occupations & 40,000 & 2.3 & high \\
\hline Associate prof. and technical occ. & 24,000 & 1.4 & average \\
\hline Clerical and secretarial occupations & $-8,000$ & -0.3 & low \\
\hline Craft and related occupations & $-26,000$ & -1.0 & low \\
\hline Personal and protective services occ. & 39,000 & 2.1 & high \\
\hline Sales occupations & $-8,000$ & -0.6 & low \\
\hline Plant and machine operatives & $-6,000$ & -0.3 & low \\
\hline Other occupations & 0,000 & 0.0 & low \\
\hline Total & 106,000 & 0.6 & average \\
\hline \multicolumn{4}{|l|}{ Northern Ireland } \\
\hline Managers and administrators & 14,000 & 1.6 & average \\
\hline Professional occupations & 12,000 & 2.3 & high \\
\hline Associate prof. and technical occ. & 6,000 & 1.4 & average \\
\hline Clerical and secretarial occupations & $-3,000$ & -0.4 & low \\
\hline Craft and related occupations & $-2,000$ & -0.3 & low \\
\hline Personal and protective services occ. & 15,000 & 2.5 & high \\
\hline Sales occupations & 1,000 & 0.3 & average \\
\hline Plant and machine operatives & $-1,000$ & -0.2 & low \\
\hline Other occupations & $-7,000$ & -1.5 & very low \\
\hline Total & 33,000 & 0.6 & average \\
\hline
\end{tabular}

Source: IER, Review of the Economy and Employment: Regional Assessment, 1994 


\section{Conclusions}

\section{Medium-term labour market forecasts: a research outline}

This report investigates the possibilities of generating medium term labour market forecasts for the various EU Member States as part of the EURES General Information Database. Information on expected developments in the labour market could be an important aid to 'enlarge the horizons' of potential migrants or commuters within a common European labour market. Moreover, this labour market information also signals the labour market possibilities for international firms (or potential international firms) which consider starting or expanding their production or services in a particular region of the European Union.

For this purpose a modular forecasting model, which produces the required medium-term forecasts in eight steps (see figure 2.1) was first formulated. However it would be superfluous to present all these labour demand and supply forecasts by economic sector, occupation and educational classification. Therefore we suggest that the EURES information system should focus on the key information that produces the labour market signals that are relevant for the intended user groups. In its complete form the forecasting model could produce three kinds of key information:

- the expansion demand by economic sector (NACE);

- the job openings by occupation (ISCO);

- the labour market prospects by educational qualification (ISCED + national classification).

The proposed modular structure offers three very important advantages:

- it enables a stepwise development of the labour market forecasts;

- it respects the principle of subsidiarity, since it builds on the existing sectoral, occupational and/or educational forecasts that are imbedded in public policies in the various Member States in general and those of the Public Employment Services in particular. This also guarantees that national information is contained in the forecasts;

- it is cost effective as it avoids double work.

We have also investigated the availability of medium-term sectoral employment forecasts in the various Member States. These forecasts are the required starting points for the proposed research model, and are the major link between the labour market forecasts presented in EURES and existing national economic forecasting activities. The investigation showed that medium-term employment forecasts are produced on a regular basis in several Member States. The number of economic sectors distinguished ranges from 5 in Denmark to 43 in Spain (see table 3.1). 
Since the EURES information system requires forecasts for all Member States of the European Union, we also discussed two previous research projects which were intended to generate employment forecasts for all Member States: the HERMES model and the ERECO forecasts. The major disadvantage of these two earlier coordinated research projects is probably that they did not build on the primary macro-economic and sectoral forecasts which are imbedded in public policies in the various Member States. Therefore we suggest that the coordination of the sectoral forecasts should be restricted to filling the gaps in the available information on the Member States.

However demand forecasts by occupational categories and educational qualifications are only available on a regular basis in a few Member States. Occupational forecasts are produced in Germany, Ireland, the Netherlands and the United Kingdom, and in the Netherlands forecasts for educational categories are also made regularly. Of course the subsidiarity principle should also apply here, but because such occupational and educational forecasts are not produced on a regular basis in many Member States, there is much more room for a more coordinated approach. Moreover, the sector by occupation and occupation by educational qualification matrices available in the Labour Force Survey of EUROSTAT are the major data source for transforming the sectoral forecasts into occupational forecasts. For this reason we investigated the data available in the Labour Force Survey of 1994 for 12 Member States. ${ }^{39}$ An analysis of the available data shows that the main problem is that educational qualifications can, at the moment, hardly be distinguished in the Labour Force Survey since the data refers only to three levels of education.

The EUROSTAT data therefore limit the labour market information that can be generated in addition to the sectoral forecasts to occupational information. In principle EUROSTAT's Labour Force Survey makes it possible to distinguish an adequate number of occupations in all Member States and in most EURES regions (see tables 4.3 and 4.4). However, partly due to the switch from the old ISCO '68 classification to the new ISCO '88 classification, there are still some severe transition problems with regard to the data availability and quality for some Member States. Moreover, it will be some years before the desired time series are available, which means that at the moment only crude forecasts of both expansion and replacement demand by occupation can be constructed.

The EUROSTAT data also offers opportunities to construct EU-wide labour market indicators that may be of great importance for the EURES information system. This is shown by the specialisation index we have constructed for the various EURES

39. No data is available for the new Member States yet. 
regions. This indicates the occupational categories in which a particular region is specialized, relative to the EU average.

Finally, two operational examples of the 'Trends' information that can be presented in the EURES information system have been described. Chapters 5 and 6 presented the available national and regional forecasts for the Netherlands and the United Kingdom, respectively. The information system of the Research Centre for Education and the Labour Market in the Netherlands regularly generates the required forecasts by both occupation and educational qualification at a national level. For this study, regional forecasts of expansion demand by occupation have also been compiled. The regular occupational forecasts of the Institute of Employment Research in the United Kingdom are restricted to the expansion demand at both national and regional level. Moreover, educational forecasts are compiled for higher education. The latter refer to both expansion demand and replacement demand.

\section{Computer screen texts}

As an aid to visualizing the information on future job opportunities that could be presented in the EURES information system, the 'Trends' information that could be given for the various regions in the Netherlands and the United Kingdom is shown in Appendices $A$ and $B$, respectively. These prototype computer screen texts focus on the most striking information available with respect to the key information on economic sectors, occupations and educational qualification. Moreover, the regional information is imbedded in the context of national labour market developments.

These examples also show the applicability of the subsidiarity-approach, in the sense that it need not be a problem if the labour market information presented for the various Member States differs to some extent due to differences in the information available.

It is however important to consider carefully whether the information to be presented should refer only to the most striking 'winners and losers' in the various regional labour markets. Although such an approach has the advantage that the users of the information system do not have to struggle with labour market information on a large number of economic sectors, occupations and educational qualifications, it has the disadvantages that persons or firms who are interested in labour market information for a particular occupation or educational qualification can often not find this information. An alternative would be to develop screen texts for each region for all economic sectors, occupations and educational qualifications. However this would require the labour market forecasts to be presented in a menu-driven tree structure that facilitates users' search processes. 
Another problem to be addressed is the dual character of the intended user groups for the EURES labour market information system. Persons searching for future job opportunities should receive information in a different form to firms who are interested in the labour market situation, as it affects their activities, in an EU region. Both the emphasis of the key information to be presented and the way it is presented in texts should be different for these two user groups. The sample screen texts in Appendices $A$ and $B$ would be typical presentations for individuals who want information about the future labour market opportunities in a particular region. For firms, it would be more relevant to emphasize any skill shortages which are forecast or the educational qualifications which are in relative abundance in an EU region. Probably it is most efficient to deduce two different ways of presentation from one central database.

\section{Towards a EURES Database of regional labour market forecasts}

Since a huge effort will be required to generate the key information for economic sectors, occupations and educational qualifications for all Member States of the European Union, a pragmatic stepwise development of the EURES labour market information system is recommended (see also Teunis and De Grip, 1996). As mentioned above, earlier attempts to generate coordinated labour market forecasts for all Member States have not been continued. A major disadvantage of these forecasting models was that they did not build on the existing macro-economic and sectoral forecasts in the various Member States. The EURES forecasts should therefore take the principle of national subsidiarity as a starting point, as is the case with the currently available EURES Database.

It is also an important advantage that - in contrast to the earlier coordinated forecasting models - the labour market forecasts constructed on behalf of EURES serve a crucial policy target: to increase the transparency of the European labour market so as to improve the overall performance of this labour market. Moreover, EURES offers a concrete tool which has the potential to disseminate the information on a large scale among EU citizens.

The proposed stepwise development of the labour market forecasts should combine a long-term strategy focusing on the development of a complete information system that includes all key information for economic sectors, occupations and educational qualifications for all EU Member States with a short-term strategy which makes it possible to feed the information system with the available relevant labour market information as soon as possible. The latter has the important advantage that the feedback of users could strengthen the further development of both the contents and the presentation of the labour market information provided. 
In particular, an investigation of the available EUROSTAT Labour Force Data indicates that it is probably most effective to focus this short-term strategy on the relevant sectoral and occupational forecasts. Since forecasts by educational qualification are still lacking for most Member States, the occupational forecasts can provisionally be supplemented by the more qualitative experts' judgements in areas such as skill shortages, obtained by sampling using the EURES' PES questionnaire.

In the light of these considerations, we suggest the following lines of action to develop the required future labour market information step-by-step:

1. Presentation of the labour market information generated in this study for the Netherlands and the United Kingdom and the occupational specialisation indices for the other Member States in the EURES information system in combination with the information currently available in the EURES Database as e.g. the information derived from the PES-Questionnaire.

2. Adding the available employment forecasts by economic sector in the other Member States and the available occupational forecasts in Belgium, Germany and Ireland, along with the forecasts by educational qualification which are available for Finland and Norway.

3. Establish a research network of forecasting institutes with the aim of developing (1) national sectoral forecasts for the Member States for which these forecasts are not yet available, (2) regional sectoral forecasts for the Member States for which these forecasts are not available and (3) the missing occupational expansion demand and replacement demand forecasts, using EUROSTAT's Labour Force Survey. This network should also be the regular supplier of the labour market forecasts required for the EURES Database. Within the actual structure of EURES it would be most appropriate if the National Public Employment Services play an active role in stimulating the forecasting activities for their own country. Probably European programmes as e.g. the Leonardo programme could facilitate the network activities required for a Europe-wide co-ordinated approach.

However, both the sectoral forecasts and the occupational and educational forecasts will probably also be useful for other policy purposes of the European Commission, both within and outside DG V. Cooperation in financing the research network will probably be an effective strategy to develop the required labour market forecasts. In this respect also the Circle for Research Cooperation on Trends in Occupations and Qualifications (CIRETOQ) network recently set up by CEDEFOP should be mentioned. 
4. Initiate a research project to investigate the availability of national forecasts of the numbers of school-leavers entering the labour market and/or the required underlying data on student numbers and student flows in initial and continuing education. $^{40}$

5. For the future development of the labour market information presented by EURES it is also of great importance to organize systematic evaluations of the usefulness of the information for the various users of the system. The Euroadvisors could probably play a central role in generating this feedback with regard both to the contents and the presentation of the labour market information provided.

6. Encouraging the improvement of EUROSTAT's labour force data by educational qualification, by differentiating more types of education at each level. For this purpose, the existing ISCED classification should be further developed by extending the differentiation of the various educational qualifications to the relevant types of education. However, due to the institutional differences between the educational systems in the Member States, there should be some room for country specific differentiation in the educational qualifications distinguished.

40. As mentioned before this information is highly relevant for firms which consider starting or expanding their production or services in a particular EU region. Moreover, this school leavers information is required for matching the labour demand forecasts with forecasts of labour supply. 


\section{References}

d'Alcantara, G. and A. Italianer, European Project for a Multinational Macrosectoral Model, Commission of the European Communities, DG XII, Documents MS-11, Brussels, 1982.

Berendsen, H., A. de Grip, M.H. Wieling and E.J.T.A. Willems, Regional labour market forecasts by education and occupation in the Netherlands, ROA-RM-1992/5E, Maastricht, 1992.

Borghans, L., A. de Grip, A.G.M. Matheeuwsen, W. Smits, E.J.T.A. Willems, Methodiek van

het informatiesysteem ondenwijs-arbeidsmarkt 1995, ROA-W-1995/3, Maastricht, 1995.

Borghans, L., H. Heijke, Forecasting the Educational Structure of Occupations: a Manpower Requirement Approach with Substitution, ROA-RM-1993/2E, 1993.

Commission of the European Communities, HERMES: Harmonised Econometric Research for Modelling Economic Systems, North-Holland, 1993.

Dam, J.W. van, A. de Grip, H. Heijke, Towards a Maas-Rhine European Labour Market, in: European Business and Economic Development (EBED), vol. 1, no. 6, 1993, pp. 14-18.

Eijs, P. van, The manpower requirements approach: background and methodology, ROA-RM1993/3E, Maastricht, 1993

Eijs, P. van, Manpower forecasting in the western world: the current state of the art, ROA-RM1994/1E, Maastricht, 1994

ERECO, Medium-term Forecasts of Employment by EU districts and Sectors of Industry: Summary Report, Ifo Institute for Economic Research, Munich, 1994

European Commission, Employment in Europe 1993, Luxembourg, 1993.

Glytsos, Nicholas, P., Demographic Changes, and Labour Shortages in Greece: An Occupational and Regional Outlook, KEPE, Athens, 1993.

Grip, A. de and J.A.M. Heijke, The Information System on Education and the Labour Market developed by ROA, ROA-W-1991/2E, Maastricht, 1991.

Grip, A. de, L. Borghans, E. Willems, Methodology of the ROA information system on occupational groups and types of education, ROA-W-1995/1E, Maastricht, 1995.

Hoevenberg, J., A. de Grip, Indicators of Occupational Employment in the European Union, ROA-R-1994/3E, Maastricht, 1994.

Institute for Employment Research, Review of the Economy and Employment: Regional Assessment 1994, University of Warwick, Coventry, 1994.

Institute for Employment Research, Review of the Economy and Employment: Occupational Assessment 1995, University of Warwick, Coventry, 1995a.

Institute for Employment Research, Review of the Economy and Employment: Future Employment Prospects for the Highly Qualified, University of Warwick, Coventry, 1995b.

Jansen, M., H. Meijers, J. van der Meulen, J. Muysken, M. Oude Wansink, P. Verberne, A van der Zon, Technical change, unemployment and skill mismatch (preliminary draft), Maastricht, 1994.

Natzijl, H. and P. Westra, Regionale Arbeidsmarktprognose 1991-1996, OAV-rapport 91-08, Rijswijk, 1991.

Natzijl, H. and P. Westra, Regionale Arbeidsmarktprognose 1995-2000, O\&A-rapport 95-07, Rijswijk, 1995

Nijkamp, P., P. Rietveld and F. Snickars, 'Regional and econometric models', in P. Nijkamp (ed.), Handbook of Regional and Urban Economics, Amsterdam/New York/Oxford/Tokyo: North-Holland, pp. 257-294, 1986.

OECD, Employment Outlook 1994, Paris, 1994

ROA, The Labour Market by Education and Occupation to 2000, ROA-R-1995/3E, Maastricht, 1995 a.

ROA, The Labour Market by Education and Occupation to 2000. Statistical Appendix, ROA-R1995/3BE, Maastricht, 1995b.

Teunis, U., A. de Grip, International Labour Market Indicators: a proposal for development, ROA-R-1996/2E, Maastricht. 
Wilson, R.A., 'Modelling and Forecasting the Structure of Employment in the UK', in H. Heijke (ed.), Labour Market Forecasts by Occupation and Education.. Massachusetts, USA: Kluwer Academic Press, 1994. 


\title{
Appendix A Presentation of information on the futu- re job opportunities in the Netherlands for the EURES system
}

\author{
Groningen ${ }^{41}$ \\ Occupational specialization
}

The occupational profile of the Province of Groningen, relative to the EU-averages, shows that the following occupational groups are strongly over-represented: Business services agents and trade brokers; Artistic, entertainment and sports associate professionals; Health associate professionals (except nursing); Nursery and midwifery associate professionals; Archivists, librarians etc; Printing-, binding-, and paper-products etc; Nursing and midwifery professionals; Managers of small enterprises; Agricultural and other mobile plant operators; Directors and chief executives.

With respect to the number of workers the largest occupational groups are:

$$
\text { Employed persons }
$$

Managers of small enterprises

14,600

Personal care and related workers

10,400

Nursery and midwifery associate professionals $\quad 9,300$

Administrative associate professionals $\quad 8,400$

$\begin{array}{ll}\text { Other office clerks } & 8,100\end{array}$

Secondary education teaching professionals $\quad 7,700$

$\begin{array}{ll}\text { Motor vehicle drivers } & 6,400\end{array}$

Shop, stall and market salespersons etc $\quad 6,300$

$\begin{array}{ll}\text { Numerical clerks } & 6,100\end{array}$

$\begin{array}{lr}\text { Production and operations managers } & 5,900\end{array}$

Forecasts

For the coming years, employment growth in the Netherlands is expected to be highest in the health sector, the miscellaneous commercial services, commerce and the chemical industry. In Groningen, employment growth will be highest in miscel-

41. In the separately published Appendices of this report similar information is presented for the other 11 provinces of the Netherlands. 
laneous commercial services and in construction. The fast growing occupations in Groningen are expected to be:

Average annual growth \%

till 2000

Programmers and system analysts.

Senior finance and sales managers

Managers and supervisors in manufacturing

Sales assistants

1.9

On the other hand, employment for agricultural workers, farmers, porters, cleaners and domestics, welders and engineering workers and purchasing and sales clerks will shrink considerably.

Forecasts for the Netherlands show that over the next few years replacement demand will be particularly high for intermediate electrical engineers, civil servants (public administation), student nurses and home nursing personnel, machinery mechanics and instrument makers, pastoral vocations and painters.

There are a large number of educational qualifications which offer good future labour market prospects for new entrants to the labour market. These are, by level of education:

Preparatory Vocational Education: Transport and harbour, Community care, hotel and catering.

Intermediate Vocational Education: Legal and fiscal, Micro-mechanical technology, Medical laboratory, Police, fire and defense, Transport and harbour, Printing technology, Textile and leather technology and Nursing and paramedical services.

Higher Vocational Education: Accounting, Commercial information science, Transport and harbour, Construction and civil engineering, Technical laboratory, Medical laboratory, Fine Arts, Legal and fiscal, Teacher training, Electronic and information technology, Nursing and paramedical services, Interpreter and translator, Mechanical engineering, Social and cultural and Police, fire and defense.

University Education: Civil engineering, Theology, Mathematics and natural sciences, Veterinary and medical sciences and dentistry, Electrical engineering and information technology, Economics, econometrics and business administration, Public administration, Information science, Social sciences, Pharmacy, Agriculture and environmental science and Mechanical engineering. 
On the other hand there are some types of education which offer bad future labour market prospects for new entrants to the labour market:

Preparatory Vocational Education: Food trades and Commerce.

Intermediate Vocational Education: Tourism and recreation, Automobile technology and Social and cultural.

Higher Vocational Education: Commerce.

University Education: Fine Arts.

For more information see:

ROA, The labour market by education and occupation to 2000, ROA-R-1995/3E, Maastricht, 1995 (tel. + 3143 3883751). 



\title{
Appendix B Presentation of information of future job opportunities in the United Kingdom for the EURES system
}

\author{
South East/Greater London ${ }^{42}$ \\ Occupational specialization
}

The occupational profile of the South East/Greater London region, relative to the EU-average, shows that the following occupational groups are strongly over-represented: Other specialist managers; Mathematicians, statisticians and related professionals; Production and operations managers; Senior officials of special-interest organisations; Nursing and midwifery professionals; Travel attendants and related workers; Artistic, entertainment and sports associate professionals; Legislators and senior government officials; Optical and electronic equipment operators; Computing professionals; Library, mail and related clerks; Writers and creative or performing artists; College, university and higher education teaching professionals; Physicists, chemists and related professionals; Special education teaching professionals.

With respect to the number of workers the largest occupational groups are:

Employed persons

1994

Other specialist managers

599,900

Production and operations managers

470,400

$\begin{array}{ll}\text { Secretaries and keyboard-operating clerks } & 371,900\end{array}$

$\begin{array}{ll}\text { Shop, stall and market salespersons etc } & 366,300\end{array}$

$\begin{array}{ll}\text { Other office clerks } & 274,600\end{array}$

Finance and sales associate professionals $\quad 265,600$

$\begin{array}{ll}\text { Domestic and related helpers, cleaners etc } & 252,100\end{array}$

$\begin{array}{ll}\text { Personal care and related workers } & 238,400\end{array}$

$\begin{array}{lr}\text { Numerical clerks } & 233,600\end{array}$

$\begin{array}{ll}\text { Housekeeping and restaurant services workers } & 227,100\end{array}$

42. In the separately published Appendices of this report similar information is presented for the other 10 regions in the United Kingdom. 
Forecasts

For the coming years, employment growth in the UK is expected to be highest in banking and business services, hotels and catering and the professional and other services. The fast growing occupations are expected to be:

Annual growth \%

Various professional occupations $\quad 5.2$

Personal service occupations $\quad 3.6$

Various associate professional occupations $\quad 3.2$

Science and engineering professionals $\quad 2.4$

Corporate managers and administrators $\quad 2.3$

In the South East the expected average employment growth is slightly above the UK average, although in Greater London the expected increase of employment is slightly below the national average. In sectoral terms, annual employment growth in the South East/Greater London region is by far the highest in business and miscellaneous services (yearly 59,000 new jobs). On the other hand, employment in all manufacturing sectors will shrink. In'occupational terms, the highest increase of employment is expected to be for the managers and administrators (yearly 44,000 new jobs), professional occupations (28,500 new jobs), associate professional and technical occupations (22,000 new jobs) and personal and protective services occupations (21,000 new jobs), while employment in clerical and secretarial occupations and for plant and machine operatives will be shrinking considerably.

The occupational employment forecasts indicate that people with managerial skills and other highly skilled workers will continue to enjoy good job opportunities in the near future. However, national forecasts for intermediate and higher skilled workers indicate substantial excess supply, in particular for teacher training and social sciences at postgraduate level, for first degree graduates in science, languages and music, and for technology and social science at intermediate level.

For more information see:

IER, Review of the Economy and Employment, 1994: Regional Assessment. Coventry, 1994: Institute for Employment Research, University of Warwick (tel. +44 1203 524127). 


\title{
Appendix C Regional, Occupational and Economic sector classifications EUROSTAT
}

\author{
NUTS II Regions \\ Belgium \\ Vlaams Gewest \\ Région Wallone \\ Brussel \\ Germany \\ Schleswig-Holstein \\ Hamburg \\ Niedersachen \\ Bremen \\ Nordrhein-Westfalen \\ Hessen \\ Rheinland-Pfalz \\ Baden-Wörtenberg \\ Bayern \\ Saarland \\ Berlin \\ Brandenburg \\ Mecklenburg-Vorpommern \\ Sachsen \\ Sachsen-Anhalt \\ Thüringen \\ Denmark \\ Denmark \\ Spain \\ Galicia \\ Asturias \\ Cantabria \\ Pais Vasco \\ Navarra \\ Rioja \\ Aragón \\ Madrid \\ Castilla-León \\ Castilla-La Mancha \\ Extremadura \\ Cataluña \\ Cummunidad Valenciana \\ Baleares \\ Andalucia \\ Murcia \\ Ceuta y Melilla* \\ Canarias \\ France \\ lle de France \\ Champagne-Ardenne \\ Picardie \\ Haute-Normandie \\ Centre \\ Basse-Normandie
}




\author{
Bourgogne \\ Nord-Pas-de-Calais \\ Lorraine \\ Alsace \\ France-Comté \\ Pays de la Loire \\ Bretagne \\ Potou-Charentes* \\ Aquitaine* \\ Midi-Pyrénées \\ Limousin \\ Rhône-Alpes \\ Auvergne \\ Languedoc-Rousillon \\ Provence-Alpes-Côte d'Azur \\ Corse \\ Greece \\ Anatoliki Makedonia, Thraki \\ Kentriki Makedonia \\ Dytiki Makedonia \\ Thessalia \\ Ipeiros \\ Ionia Nisia \\ Dytiki Ellada \\ Sterea Ellada \\ Peloponnisos \\ Attiki \\ Voreio Aigaio \\ Notio Aigaio \\ Kriti \\ Ireland \\ East** \\ South West \\ South East \\ North East \\ Mid-West \\ North West and Donegal \\ Midlands \\ West \\ Italy \\ Piemonte \\ Valle d'Aosta \\ Liguria \\ Lomdardia \\ Trentino-Alto Adige \\ Veneto \\ Fruiti-Venezia Giulia \\ Emilia-Romagna \\ Toscana \\ Umbria \\ Marche \\ Lazio \\ Campania \\ Abruzzi \\ Molise \\ Puglia \\ Basillicata \\ Calabria
}


Sicilia

Sardegna

Luxembourg

Luxembourg

Netherlands

Groningen

Friesland

Drenthe

Overijssel

Gelderland

Flevoland

Utrecht

Noord-Holland

Zuid-Holland

Zeeland

Noord-Brabant

Limburg

Portugal

Norte

Centro

Lisboa e Vale do Tejo

Alentejo

Algarve

Açores

Madeira*

United Kingdom

North

Yorkshire and Humberside

East Midlands

East Anglia

South East

South West

West Midlands

North West

Wales

Scotland

Nortern Ireland

* not distinguished in the EURES Database

** in the EURES Database this region is subdivided into three regions 


\section{Occupations, ISCO'88}

1 Legislators, senior officials and managers

11 Legislators and senior officials

111 Legislators and senior government officials

114 Senior officials of special-interest organisations

12 Corporate managers

121 Directors and chief executives

122 Production and operations managers

123 Other specialist managers

13 Managers of small enterprises

131 Managers of small enterprises

\section{Professionals}

21 Physical, mathematical and engineering science professionals

211 Physicists, chemists and related professionals

212 Mathematicians, statisticians and related professionals

213 Computing professionals

214 Architects, engineers and related professionals

22 Life science and health professionals

221 Life science professionals

222 Health professionals (except nursing)

223 Nursing and midwifery professionals

23 Teaching professionals

231 College, university and higher education teaching professionals

232 Secondary education teaching professionals

233 Primary and pre-primary education teaching professionals

234 Special education teaching professionals

235 Other teaching professionals

24 Other professionals

241 Business professionals

242 Legal professionals

243 Archivists, librarians and related information professionals

244 Social science and related professionals

245 Writers and creative or performing artists

246 Religious professionals

247 Public service administrative professionals

\section{Technicians and associate professionals}

31 Physical and engineering science ásso. professionals

311 Physical and engineering science technicians

312 Computer associate professionals

313 Optical and electronic equipment operators

314 Ship and aircraft controllers and technicians

315 Safety and quality inspectors

32 Life science and health associate professionals

321 Life science technicians and related associate professionals

322 Health associate professionals (except nursing)

323 Nursery and midwifery associate professionals

33 Teaching associate professionals

331 Primary education teaching associate professionals

332 Pre-primary education teaching associate professionals

333 Special education teaching associate professionals

334 Other teaching associate professionals

34 Other associate professionals

341 Finance and sales associate professionals

342 Business services agents and trade brokers

343 Administrative associate professionals 
344 Customs, tax and related government associate professionals

345 Police inspectors and detectives

346 Social work associate professionals

347 Artistic, entertainment and sports associate professionals

348 Religious associate professionals

\section{$4 \quad$ Clerks}

41 Office clerks

411 Secretaries and keyboard-operating clerks

412 Numerical clerks

413 Material-recording and transport clerks

414 Library, mail and related clerks

419 Other office clerks

42 Customer services clerks

421 Cashiers, tellers and related clerks

422 Client information clerks

\section{$5 \quad$ Service workers and shop and market sales workers}

51 Personal and protective services workers

511 Travel attendants and related workers

512 Housekeeping and restaurant services workers

513 Personal care and related workers'

514 Other personal services workers

516 Protective services workers

52 Models, salespersons and demonstrators

521 Fashion and other models

522 Shop, stall and market salespersons etc

\section{$6 \quad$ Skilled agricultural workers}

61 Skilled agricultural and fishery workers

611 Market gardeners and crop growers

612 Animal producers and related workers

613 Crop and animal producers

614 Forestry and related workers

615 Fishery workers, hunters and trappers

\section{Craft and related trades workers}

71 Extraction and building trades workers

711 Miners, shotfirers, stone cutters and carvers

712 Building frame and related trades workers

713 Building finishers and related trades workers

714 Painters, building structure cleaners etc

72 Metal, machinery and related trades workers

721 Metal moulders, welders, sheet-metal workers, and related trades workers

722 Blacksmiths, tool-makers and related trades workers

723 Machinery mechanics and fitters

724 Electrical and electronic equipment mechanics etc

73 Precision, handicraft, craft printing and etc

731 Precision workers in metal and related materials

732 Potters, glass-makers and related trades workers

733 Handicraft workers in wood, textile, leather and related materials

734 Craft printing and related trades workers

74 Other craft and related trades workers

741 Food processing and related trades workers

742 Wood treaters, cabinet-makers and related trades workers

743 Textile, garment and related trades workers

744 Pelt, leather and shoemaking trades workers 
$8 \quad$ Plant and machine operators and assemblers

81 Stationary-plant and related operators

811 Mining and mineral-processing-plant operators

812 Metal-processing plant operators

813 Glass, ceramics and related plant operators

814 Wood-processing- and papermaking-plant operators

815 Chemical-processing-plant operators

816 Power-production and related plant operators

817 Industrial robot operators

82 Machine operators and assemblers

821 Metal- and mineral-products machine operators

822 Chemical-products machine operators

823 Rubber- and plastic-products machine operators

824 Wood-products machine operators

825 Printing-, binding-, and paper-products etc

826 Textile-, fur- and leather-products machine operators

827 Food and related products machine operators

828 Assemblers

829 Other machine operators n.e.c.

83 Drivers and mobile plant operators

831 Locomotive engine drivers and related workers

832 Motor vehicle drivers

833 Agricultural and other mobile plant operators

834 Ships' deck crews and related workers

\section{$9 \quad$ Elementary occupations}

91 Sales and services

911 Street vendors and related workers

912 Shoe cleaning and other street services etc

913 Domestic and related helpers, cleaners etc

914 Building caretakers, window and related cleaners

915 Messengers, porters, doorkeepers etc

916 Garbage collectors and related labourers

92 Agricultural, fishery and related labourers

921 Agricultural, fishery and related labourers

93 Labourers in mining, construction, manuf. and trans.

931 Mining and construction labourers

932 Manufacturing labourers

933 Transport labourers and freight handlers

\section{$0 \quad$ Armed forces}

01 Armed forces

011 Armed forces 


\section{Economic sector, NACE rev. 1}

A Agriculture, hunting and forestry

\section{B Fishing}

C Mining and quarrying

D Manufacturing

E Electricity, gas and water supply

F Construction

G Wholesale and retail trade, repair

$\mathrm{H} \quad$ Hotels and restaurants

I Transport, storage and communication

$\mathrm{J}$ Financial intermediation

$\mathrm{K}$ Real estate, renting and business activities

$\mathrm{L} \quad$ Public administration and defence etc

$M \quad$ Education

$\mathrm{N}$ Health and social work

O Other community, social and personal service activities

$P \quad$ Private households with employed persons

$Q \quad$ Extra-territorial organizations and bodies 



\section{Appendix D IER's educational qualification}

Table D.1

Levels of qualification distinguished by the IER

Level of qualification

- $\quad$ Higher university degrees (postgraduate)

- $\quad$ First degree and all other qualifications of equivalent standard

- $\quad$ Qualifications obtained at 18 years of age or above, beyond 'A' level but below first degree. This includes most nursing and many teaching qualifications (intermedaite)

Source: IER

Table D.2

Subjects of qualification distinguished by the IER

Subject of qualification

- Education

- Health, Medicine and Dentistry

- $\quad$ Technology and Engineering

- $\quad$ Agriculture, Forestry and Veterinary Studies

- $\quad$ Science (including mathematics and applied science)

- $\quad$ Social, Administrative and Business Studies (including accountancy and law)

- Vocational (including Architecture and other professional studies)

- $\quad$ Language (Literature and Area) Studies

- $\quad$ Arts (other than Language and Performing Arts)

- Music, Drama and Visual Arts

Source: IER 



\section{Appendix E Regional tables EU}

Table E.1

Occupations with the largest number of employed persons by region and Member State of the European Union, 1994

\section{PORTUGAL ${ }^{43}$}

Norte

Managers of small enterprises

Textile, garment and related trades workers

Market gardeners and crop growers

115,200

Numerical clerks

74,400

Shop, stall and market salespersons etc

65,100

Building frame and related trades workers

64,800

Pelt, leather and shoemaking trades workers $\quad 53,500$

Other personal services workers $\quad 50,500$

Secondary education teaching professionals $\quad 43,500$

$\begin{array}{ll}\text { Agricultural, fishery and related labourers } & 39,300\end{array}$

\section{Centro}

Market gardeners and crop growers $\quad 136,400$

Shop, stall and market salespersons etc $\quad 42,600$

Other office clerks $\quad 36,200$

Textile-, fur- and leather-product machine operators $\quad 32,400$

Building frame and related trades workers $\quad 29,800$

Managers of small enterprises $\quad 28,700$

Housekeeping and restaurant services workers $\quad 25,400$

$\begin{array}{ll}\text { Motor vehicle drivers } & 21,100\end{array}$

Domestic and related helpers, cleaners etc $\quad 21,000$

Secondary education teaching professionals $\quad 19,800$

Lisboa e Vale do Tejo

Secretaries and keyboard-operating clerks $\quad 144,100$

Managers of small enterprises $\quad 100,900$

$\begin{array}{ll}\text { Shop, stall and market salespersons etc } & 78,300\end{array}$

Housekeeping and restaurant services workers $\quad 62,200$

Domestic and related helpers, cleaners etc $\quad 55,800$

Motor vehicle drivers $\quad 39,300$

Secondary education teaching professionals $\quad 37,100$

$\begin{array}{ll}\text { Numerical clerks } & 36,400\end{array}$

Administrative associate professionals $\quad 35,200$

Building frame and related trades workers $\quad 33,500$

43. In the separately published Appendices of this report similar regional information is presented for the other EU Member States. 
Table E.1 (continued)

Occupations with the largest number of employed persons by region and Member State of the European Union, 1994

\section{Alentejo}

Managers of small enterprises $\quad 16,900$

Housekeeping and restaurant services workers $\quad 9,700$

Agricultural, fishery and related labourers $\quad 9,500$

Other personal services workers $\quad 9,400$

Market gardeners and crop growers $\quad 8,800$

Building frame and related trades workers $\quad 7,700$

Shop, stall and market salespersons etc $\quad 7,400$

$\begin{array}{ll}\text { Mining and construction labourers } & 7,300\end{array}$

Motor vehicle drivers $\quad 6,800$

$\begin{array}{ll}\text { Numerical clerks } & 6,600\end{array}$

\section{Algarve}

Managers of small enterprises

eeping and restaurant services workers

Shop, stall and market salespersons etc $\quad 9,200$

Market gardeners and crop growers $\quad 7,800$

Numerical clerks $\quad 6,900$

Building frame and related trades workers $\quad 6,200$

Other personal services workers $\quad 6,000$

Fishery workers, hunters and trappers $\quad 3,500$

Personal care and related workers $\quad 3,500$

Domestic and related helpers, cleaners etc $\quad 3,400$

\section{Acores}

Building frame and related trades workers $\quad 8,300$

Animal producers and related workers $\quad 7,500$

Shop, stall and market salespersons etc $\quad 5,000$

$\begin{array}{ll}\text { Managers of small enterprises } & 4,200\end{array}$

Other personal services workers $\quad$ 3,800

Market gardeners and crop growers $\quad 3,700$

$\begin{array}{lr}\text { Motor vehicle drivers } & 3,200\end{array}$

Food processing and related trades workers $\quad 3,000$

Secretaries and keyboard-operating clerks $\quad 2,500$

$\begin{array}{ll}\text { Numerical clerks } & 2,400\end{array}$

Madeira

Textile, garment and related trades workers $\quad 13,500$

Market gardeners and crop growers $\quad 10,600$

$\begin{array}{lr}\text { Housekeeping and restaurant services workers } & 6,400\end{array}$

$\begin{array}{ll}\text { Mining and construction labourers } & 6,100\end{array}$

Domestic and related helpers, cleaners etc $\quad 5,600$

Shop, stall and market salespersons etc $\quad 4,600$

Building frame and related trades workers $\quad 4,400$

$\begin{array}{ll}\text { Motor vehicle drivers } & 3,700\end{array}$

$\begin{array}{ll}\text { Other personal services workers } & 3,400\end{array}$

Managers of small enterprises $\quad 3,200$

Source: EUROSTAT, LFS 
Table E.2

Number of workers per occupation at 1 digit level by region, 1994

\section{GERMANY ${ }^{44}$}

Schleswig-Holstein

Technicians and associate professionals

Craft and related trades workers

204,000

Service workers and shop and market sales workers $\quad 133,600$

Clerks

125,500

Elementary occupations

115,600

Professionals

112,600

Plant and machine operators and assemblers $\quad 83,400$

Legislators, senior officals and managérs $\quad 56,800$

Skilled agricultural and fishery workers 46,000

$\begin{array}{lr}\text { Armed forces } & 23,900\end{array}$

Hamburg

Technicians and associate professionals $\quad 166,600$

Clerks $\quad 131,300$

Professionals $\quad 117,200$

Elementary occupations $\quad 92,700$

Craft and related trades workers $\quad 91,500$

Service workers and shop and market sales workers $\quad 75,100$

Legislators, senior officals and managers $\quad 47,900$

Plant and machine operators and assemblers $\quad 45,300$

$\begin{array}{lr}\text { Skilled agricultural and fishery workers } & 8,200\end{array}$

Armed forces $\quad 4,300$

Niedersachsen

$\begin{array}{ll}\text { Craft and related trades workers } & 603,000\end{array}$

Technicians and associate professionals $\quad 586,100$

$\begin{array}{ll}\text { Clerks } & 445,300\end{array}$

Elementary occupations $\quad 400,400$

Service workers and shop and market sales workers $\quad 375,800$

$\begin{array}{ll}\text { Professionals } & 348,000\end{array}$

Plant and machine operators and assemblers $\quad 236,800$

Legislators, senior officals and managers $\quad 178,100$

$\begin{array}{lr}\text { Skilled agricultural and fishery workers } & 99,000\end{array}$

Armed forces $\quad 34,200$

Bremen

Technicians and associate professionals $\quad 50,100$

$\begin{array}{ll}\text { Craft and related trades workers } & 50,000\end{array}$

$\begin{array}{ll}\text { Clerks } & 46,200\end{array}$

$\begin{array}{ll}\text { Professionals } & 35,800\end{array}$

Elementary occupations $\quad 30,100$

Service workers and shop and market sales workers $\quad 29,900$

Plant and machine operators and assemblers $\quad 19,900$

Legislators, senior officals and managers $\quad 14,100$

Armed forces

$\begin{array}{lr}\text { Skilled agricultural and fishery workers } & 2,700\end{array}$

44. In the separately published Appendices of this report similar regional information is presented for the other EU Member States. 
Table E.2 (continued)

Number of workers per occupation at 1 digit level by region, 1994

Member State and Region

Number of workers

Nordrhein-Westfalen

Craft and related trades workers

$1,327,400$

Technicians and associate professionals

Clerks

Elementary occupations

$1,326,600$

$1,085,700$

Professionals

824,000

812,100

771,700

$\begin{array}{ll}\text { Plant and machine operators and assemblers } & 778,700 \\ \text { Legislators, senior officals and managers } & 424,200\end{array}$

$\begin{array}{ll}\text { Legislators, senior officals and managers } & 424,200 \\ \text { Skilled agricultural and fishery workers } & 116,700\end{array}$

Armed forces

47,100

Hessen

Technicians and associate professionals $\quad 529,200$

Craft and related trades workers $\quad 424,800$

$\begin{array}{ll}\text { Clerks } & 418,900\end{array}$

Professionals $\quad 327,600$

Elementary occupations $\quad 285,300$

Service workers and shop and market sales workers $\quad 263,800$

Legislators, senior officals and managers $\quad 166,300$

Plant and machine operators and assemblers $\quad 164,800$

$\begin{array}{lr}\text { Skilled agricultural and fishery workers } & 45,300\end{array}$

14,300

Rheinland-Pfalz

Technicians and associate professionals $\quad 343,300$

$\begin{array}{ll}\text { Craft and related trades workers } & 320,800\end{array}$

231,300

Service workers and shop and market sales workers $\quad 187,300$

$\begin{array}{ll}\text { Plant and machine operators and assemblers } & 168,100\end{array}$

Professionals $\quad 167,300$

Elementary occupations $\quad 127,200$

Legislators, senior officals and managers $\quad 75,300$

Skilled agricultural and fishery workers $\quad 45,400$

$\begin{array}{ll}\text { Armed forces } & 15,000\end{array}$

Baden-Worthenberg

Craft and related trades workers $\quad 957,900$

Technicians and associate professionals $\quad 855,300$

Professionals $\quad 525,900$

Elementary occupations

Service workers and shop and market sales workers $\quad 440,600$

Plant and machine operators and assemblers $\quad 333,400$

Legislators, senior officals and managers $\quad 251,300$

Skilled agricultural and fishery workers $\quad 93,300$

$\begin{array}{ll}\text { Armed forces } & 13,400\end{array}$

Source: EUROSTAT, LFS 
Table E.3

Regional occupational specialization of the EU regions, 1994

Member State, region and occupation

specialization-index

SPAIN $^{45}$

Galicia

Fishery workers, hunters and trappers . $\quad 26.0$

Animal producers and related workers $\quad 12.7$

$\begin{array}{lr}\text { Crop and animal producers } & 11.4\end{array}$

Ships deck crews and related workers $\quad 7.6$

Managers of small enterprises 2.9

Market gardeners and crop growers $\quad 2.8$

Miners, shotfirers, stone cutters and carvers $\quad 2.5$

Mining and construction labourers $\quad 2.2$

Building frame and related trades workers 2.1

Asturias

Animal producers and related workers

Miners, shotfirers, stone cutters and carvers $\quad 9.7$

\begin{tabular}{ll} 
Metal-processing plant operators & 9.2 \\
\hline
\end{tabular}

Primary and pre-primary education teaching prof. $\quad 2.8$

Mining and construction labourers $\quad 2.6$

Managers of small enterprises $\quad 2.1$

Cantabria

Animal producers and related workers $\quad 12.7$

Fishery workers, hunters and trappers $\quad 12.5$

$\begin{array}{lr}\text { Mining and construction labourers } & 3.1\end{array}$

Primary and pre-primary education teaching prof. $\quad 3.1$

Managers of small enterprises $\quad 2.8$

Metal- and mineral-product machine operators $\quad 2.8$

Motor vehicle drivers $\quad 2.2$

Food processing and related trades workers $\quad 2.2$

Pais Vasco

$\begin{array}{ll}\text { Rubber- and plastics-products machine operators } & 7.1\end{array}$

Metal- and mineral-product machine operators 6.5

Metal-processing plant operators $\quad 4.1$

Fishery workers, hunters and trappers $\quad 4.1$

Forestry and related workers 3.3

Chemical-products machine operators $\quad 2.7$

Primary and pre-primary education teaching prof. $\quad 2.5$

Other teaching professionals 2.2

Garbage collectors and related labourers $\quad 2.1$

Physicists, chemists and related professionals 2.1

Travel attendants and related workers $\quad 2.1$

Navarra

Assemblers $\quad 4.8$

Food and related products machine operators $\quad 3.5$

Food processing and related trades workers 3.3

Primary and pre-primary education teaching prof. $\quad 2.8$

Mining and construction labourers

Textile-, fur- and leather-product machine operators 2.4

45. In the separately published Appendices of this report similar regional information is presented for the other EU Member States. 
Table E.3 (continued)

Regional occupational specialization of the EU regions, 1994

Member State, region and occupation

specialization-index

Rioja

Textile-, fur- and leather-product machine operators

Market gardeners and crop growers $\quad 3.9$

Food processing and related trades workers

Primary and pre-primary education teaching prof. $\quad 2.7$

Managers of small enterprises $\quad 2.4$

Aragon

Mining and construction labourers

Assemblers

Rubber- and plastics-products machine operators

Market gardeners and crop growers

Metal- and mineral-product machine operators

Textile-, fur- and leather-product machine operators

Agricultural, fishery and related labourers

Animal producers and related workers $\quad 2.4$

Primary and pre-primary education teaching prof.

Building caretakers, window and related cleaners

Managers of small enterprises $\quad 2.1$

Madrid

14.2

Special education teaching professionals

Mining and mineral-processing-plant operators $\quad 3.0$

Secretaries and keyboard-operating clerks

Legal professionals 2.6

Physicists, chemists and related professionals

Messengers, porters, doorkeepers etc

Craft printing and related trades workers

Social science and related professionals

Street vendors and related workers

Garbage collectors and related labourers $\quad 2.1$

Castilla-Leon

Industrial robot operators

Miners, shotfirers, stone cutters and carvers $\quad 6.6$

Animal producers and related workers

Crop and animal producers

Mining and construction labourers

Forestry and related workers

Market gardeners and crop growers

Managers of small enterprises

Rubber- and plastics-products machine,operators

Food processing and related trades workers

Wood-processing- and papermaking-plant operators 2.2 
Table E.3 (continued)

Regional occupational specialization of the EU regions, 1994

Member State, region and occupation

specialization-index

Castilla-La Marcha

Textile-, fur- and leather-product machine operators $\quad 5.5$

Mining and construction labourers $\quad 4.3$

Market gardeners and crop growers $\quad 4.1$

Animal producers and related workers $\quad 3.3$

Managers of small enterprises $\quad 2.9$

$\begin{array}{ll}\text { Food processing and related trades workers } & 2.7\end{array}$

\begin{tabular}{ll} 
Street vendors and related workers & 2.4 \\
\hline
\end{tabular}

Agricultural, fishery and related labourers

Agricultural and other mobile plant operators $\quad 2.3$

Building frame and related trades workers 2.3

Primary and pre-primary education teaching prof. 2.2

\section{Extremadura}

Mining and construction labourers $\quad 7.8$

$\begin{array}{ll}\text { Agricultural, fishery and related labourers } & 4.9\end{array}$

Animal producers and related workers $\quad 4.7$

Market gardeners and crop growers $\quad 4.2$

Managers of small enterprises $\quad 2.6$

Primary and pre-primary education teaching prof. 2.6

\section{Cataluna}

$\begin{array}{lr}\text { Fashion and other models } & 10.1\end{array}$

\begin{tabular}{lr} 
Manufacturing labourers & 10.9 \\
\hline
\end{tabular}

Special education teaching professionals $\quad 2.8$

Rubber- and plastics-products machine operators $\quad 2.7$

Textile-, fur- and leather-product machine operators

Chemical-products machine operators $\quad 2.2$

\section{Cummunidad Valenciana}

Glass, ceramics and related plant operators

Pelt, leather and shoemaking trades workers

Textile-, fur- and leather-product machine operators $\quad 6.1$

$\begin{array}{ll}\text { Potters, glass-makers and related trades workers } & 3.8 \\ \text { Wood-products machine operators } & 2.9\end{array}$

Agricultural, fishery and related labourers 2.6

Rubber- and plastics-products machine operators $\quad 2.5$

2.5

Managers of small enterprises $\quad 2.4$

Street vendors and related workers $\quad 2.4$

Chemical-products machine operators $\quad 2.3$

Baleares

Pelt, leather and shoemaking trades workers 4.8

$\begin{array}{ll}\text { Client information clerks } & 3.8 \\ \text { Housekeeping } & 3.2\end{array}$

Housekeeping and restaurant services workers $\quad 3.2$

Managers of small enterprises $\quad 2.8$

Domestic and related helpers, cleaners etc $\quad 2.5$

Wood treaters, cabinet-makers etc 2.4

Food processing and related trades workers $\quad 2.2$ 
Table E.3 (continued)

Regional occupational specialization of the EU regions, 1994

Member State, region and occupation

specialization-index

\section{Andalucia}

Agricultural, fishery and related labourers $\quad 7.4$

Street vendors and related workers

Fishery workers, hunters and trappers $\quad 3.6$

Mining and construction labourers $\quad 3.5$

Garbage collectors and related labourers

Primary and pre-primary education teaćhing prof.

Forestry and related workers $\quad 2.6$

Managers of small enterprises

Special education teaching professionals $\quad 2.5$

Domestic and related helpers, cleaners etc $\quad 2.1$

Murcia

Agricultural, fishery and related labourers $\quad 6.2$

Fishery workers, hunters and trappers $\quad 4.6$

Street vendors and related workers

Food processing and related trades workers

Wood treaters, cabinet-makers etc

Mining and construction labourers $\quad 2.9$

Managers of small enterprises

Market gardeners and crop growers

Pelt, leather and shoemaking trades workers

Manufacturing labourers $\quad 2.1$

Ceuta y Melilla

Protective services workers $\quad 6.0$

Managers of small enterprises $\quad 4.8$

Canarias

Street vendors and related workers

Primary and pre-primary education teaching prof.

Mining and construction labourers

Housekeeping and restaurant services workers

Domestic and related helpers, cleaners etc

Managers of small enterprises

Motor vehicle drivers $\quad 2.1$ 